\title{
Provenance and age of bacteria-like structures on mid-Palaeozoic plant fossils
}

\author{
Dianne Edwards, Lindsey Axe, John Parkes and David Rickard \\ School of Earth, Ocean and Planetary Sciences, Cardiff University, Main Building, Park Place, Cardiff CF10 3 YE, UK \\ e-mail: EdwardsD2@cardiff.ac.uk
}

\begin{abstract}
Structures, termed microbioids, comforming to bacteria in size and shape (e.g. rods, spheres, chains and clusters of spheres) have been observed by field emission scanning electron microscopy (FE-SEM) on coalified Silurian and Lower Devonian spores, sporangia, cuticles and coprolites. Some were sectioned for transmission electron microscopy. The elemental composition of both microbioids and 'substrates' was investigated using a X-ray microanalysis system. These analyses combined with comparative studies on recent bacteria and cyanobacteria were undertaken to evaluate the biogenicity, nature and age of the microbioids. Spheres with a Si signature $(0.03-0.5 \mu \mathrm{m}$ diameter $)$ and assumed composed of silica are interpreted as artefacts produced abiotically during the extraction procedures. A similar origin is proposed for hollow spheres that are composed of $\mathrm{CaF}_{2}$. These occur singly, in short chains simulating filaments, and in clusters. Considerable differences in size $(0.2-2.0 \mu \mathrm{m}$ diameter) and appearance relate to local variation in the chemical environment during extraction. Spheres $(0.2-1.5 \mu \mathrm{m}$ diameter), that lack a mineral signature, with a framboidal surface ornament and occur within sporangia are identified as by-products of spore development. A biotic origin is also postulated for C-containing rod-shaped structures ( $>3.1 \mu \mathrm{m}$ long, $<1.4 \mu \mathrm{m}$ wide), some with collapsed surfaces, although comparisons with living bacteria indicate recent contamination. More elongate rod-shaped microbioids $\left(<8.6 \mu \mathrm{m}\right.$ long, $1.2 \mu \mathrm{m}$ wide) have been identified as detrital rutile crystals $\left(\mathrm{TiO}_{2}\right)$. Minute naviculate structures $(<2.2 \mu \mathrm{m}$ long) resembling diatoms are of unknown origin but are probably composed of thorium hydroxide. Unmineralized filaments of cyanobacterial morphology are recent contaminants. Some of the sporangia and spore masses are partially covered by associations of fragmented sheets, interconnecting strands, rods and spheres that are interpreted as dehydrated biofilms. Being unmineralized they are probably also of recent origin, although they might have survived wild-fire along with the charcoalified mesofossils. Many of the structures illustrated here were initially identified casually as bacteria on the small fossils extracted for biodiversity studies using well-tried, conventional, palaeobotanical techniques. Our subsequent more detailed analyses have shown how such processes can produce artefacts that are morphological analogues of mineralized bacteria, leave residues that mimic bacterial shapes and, despite some efforts such as storage in dilute $\mathrm{HCl}$ to eliminate living bacteria, introduce contamination. They reinforce previous concerns that verification of the biogenicity and syngenicity of bacterial-like objects in ancient Earth and extraterrestrial rocks should not only rely on size and morphological look-alikes, but must encompass a thorough understanding of fossilization processes and extraction techniques plus, ideally, other measures of biogenicity (e.g. biomarkers) and syngenicity.
\end{abstract}

Received 21 February 2006, accepted 26 June 2006

Key words: bacteria, biofilms, biogenicity, cyanobacteria, Devonian, mesofossils, mineralization, nanobacteria, Silurian.

\section{Introduction}

In view of the ubiquity of bacteria in the biosphere today (Whitman et al. 1998), and their roles in plant decay and fossilization processes in the near and distant past (Grimes et al. 2001, 2002), bacteria were likely to be closely associated with the vegetation whose fossilized remains we now study. Whether or not such bacteria would themselves be preserved as fossils is more conjectural, although they are recorded in exceptional preservational environments, for example in the Miocene Messel Oil Shale (Richter 1994) or the Cretaceous
Santana Formation (Martill 1987; Martill \& Wilby 1994) where abundant bacteria have become permineralized and may reproduce the shape (Hautschatten) of their hosts. Precambrian records of silicified cyanobacteria plus more equivocal coccoid forms (e.g. Fox et al. 1983) are further examples of microbial fossilization, although the authenticity of some of the oldest microfossils remains controversial (e.g. Brasier et al. 2002, 2005; Schopf et al. 2002; Westall \& Folk 2003). Controversy also centres on some very small spherical to ovoid structures (circa 25-800 nm) occurring, often in profusion, either singly or in clusters and chains in 
sedimentary rocks (e.g. carbonates (Folk 1992, 1993) and clastics (Folk \& Lynch 1997)) and on minerals (e.g. sulphides (Sillitoe et al. 1996)), and mostly revealed by acid etching. These structures were named nannobacteria (dwarf bacteria) (Folk 1992), whose charged surfaces are thought to have led to the precipitation of minerals such as calcite and aluminosilicates, although calcareous examples have been synthesized in controlled experiments under sterile conditions (Kirkland et al. 1999). Indeed the feasibility of the very existence of the smallest structures $(<50 \mathrm{~nm})$ even as prokaryotic cells has been questioned (Nealson 1997). Thus Kirkland et al. (1999, p. 50) concluded that ' ... in the natural environment it will be difficult, if not impossible, to distinguish biologic from non-biologic features solely on the basis of external morphology'.

The experimental studies of Kirkland et al. parallel those in which mineralization processes have been simulated in laboratory attempts to replicate structures described in the fossil record, or even extra-terrestrial rocks (e.g. Oehler \& Schopf 1971; Walters et al. 1977; Ferris et al. 1988; Martin et al. 2003). Among the most comprehensive studies of silicification that combine transmission electron microscopy (TEM) and scanning electron microscopy (SEM) are those of Westall et al. (1995) and Toporski et al. (2002). The former used substrates of bacteria, fungi, diatoms, deep sea communities and microbial mats that after four weeks at ambient pressures had become encrusted with silica, with some cellular penetration involving much finer grained silica. The silica, after treatment at $500 \mathrm{~atm}$, became concentrated within the cell forming a nucleus-like structure within a hollow silica crust. By contrast, Toporski et al. (2002) using hydrous sodium silicate solution as opposed to all previous experiments using tetramethylorthosilane (TEOS), an organosilicon solvent, found no cellular encrustation but nanometre sized crystallites were precipitated within cells in which some cellular details were still preserved after six months. Martin et al. (2003) in attempts to mineralize European lobster eggs in calcium carbonate and apatite, observed bacteria embedded in the encrusting mineralized layer in which $\mathrm{Ca}$ was present, but not $\mathrm{P}$, suggesting that the bacteria, presumably involved in the decay of the eggs, had themselves become impregnated with calcium carbonate.

In a different approach to mineralization, Thomas-Kerpta et al. (1998) used bacterial communities from a reducing subsurface basalt aquifer and cultured them in a medium of crushed basalt. Bacterial fossilization potential was observed by the rapid (circa eight weeks) development of mineral coatings rich in $\mathrm{Fe}, \mathrm{Si}, \mathrm{O}$ and sometimes $\mathrm{Mn}$. Quite remarkably, filaments (20-200 $\mathrm{nm}$ in diameter) interpreted as bacterial appendages were coated or replaced with a ferrihydrate mineral, and these were comparable to structures present in a Martian meteorite.

In the course of our own diversity studies on Silurian and Lower Devonian mesofossils from the Welsh Borderland (summary in Edwards \& Richardson (2004)) we have noted a number of bacteria-like objects adhering to spores, cuticles, sporangial walls and coprolites. We define these structures as microbioids: microparticles which in form, size, shape and association have microbial-like characteristics. Shapes include rods, spheres and chains or clusters of spheres, all of prokaryotic dimensions, and occasionally occurring above depressions or channels reminiscent of bacterial dissolution pits. This combination of characters appears strongly supportive of the bacterial nature of the fossils, but bearing in mind controversies surrounding body fossil evidence for the earliest life on Earth or indeed Mars (McKay et al. 1996; Toporski et al. 2003), it must be re-iterated that unequivocal biogenic validation of such structures, here termed microbioids, requires more than evidence based on size and morphology (Westall 1999). Moreover, even if biogenicity can be established on our Silurian-Devonian fossils, their syngenicity and indigenousness must also be demonstrated. Were they indeed involved in decomposition of the organisms subsequently fossilized, or have they been introduced more recently either in percolating groundwater via cracks and microfissures (Westall \& Folk 2003), or by contamination during the extraction or preparation processes? In considering spherical objects associated with sporangial contents there is a further complication. Residues produced during or following sporopollenin deposition are spheroidal (e.g. Ubisch bodies and pteridophyte analogues), and these have bacterial dimensions (Edwards et al. 1995, 2001a).

Screening procedures, carried out over the last 20 years, involved sorting of mesofossils from a particular locality into different categories; for example, sporangia, spore masses, stems, cuticles, etc. In subsequent SEM examinations, in addition to anatomical observations, we noted any adhering tubes and a wide range of structures that we initially characterized as bacteria. As part of this current project, initial search of our database of over 3000 specimens, revealed 50 promising examples, which could also be dated in terms of sample preparation. We therefore employed a number of imaging (e.g. high-resolution field emission scanning electron microscopy (FE-SEM)) and analytical (X-ray microanalysis) techniques, not previously available to us, in a systematic attempt to demonstrate the biogenicity, syngenicity and chemical composition of a variety of structures including many with somewhat simple, even monotonous morphology - approaches which may have relevance to the detection of biological entities in much older Earth and extra-terrestrial rocks.

\section{Material and methods}

\section{Specimens}

In total more than 70 fossil specimens were examined in detail, 50 had been previously imaged in a SEM for biodiversity and anatomical studies and over 20 new specimens were examined for this study. In this study 48 specimens are detailed (see Appendix A). Most of the specimens were extracted in Cardiff, apart from some of the Silurian material that was processed in Manchester University as part of a joint project with Drs Paul Selden, Andrew Jeram and Phil Manning to search for early terrestrial arthropods. The 
locations from which the specimens were obtained from were as follows.

(1) Ludford Lane Corner, near Ludlow, Shropshire: grey siltstone circa $1.6 \mathrm{~m}$ above the Ludlow Bone Bed, tripapillatus-spicula Spore Zone, Platyschisma Shale Member, basal Př́dolí: mesofossils including axes and sporangia (Hollandophyton and Salopella sp.); tube and spore masses; arthropod cuticles - stub number prefix LL (22 specimens from more than five chemical extraction batches)

(2) Targrove quarry, Downton Hall Estate, north of Ludlow, south of Brown Clee Hill, Shropshire: buff coarse micaceous siltstone, lower part of micrornatus-newportensis Spore Zone, Ditton Formation, Lochkovian: coalified spore masses; coprolites - stub number prefix $\mathrm{T}$ (two specimens from the same chemical extraction batch).

(3) Stream section, north of Brown Clee Hill, Shropshire: grey siltstone circa $200 \mathrm{~m}$ above the main Psammosteus limestone, middle part of micrornatus-newportensis Spore Zone, Ditton Formation, Lochkovian: mesofossils including sterile axes, sporangia of various Cooksonia species, Resillitheca sp., Salopella sp; cuticles, spore masses, coprolites - stub number prefix HD (24 specimens from six chemical extraction batches).

\section{Extraction techniques}

Standard procedures for maceration (roman) and departures (italics).

(1) Following excavation from, as far as possible, unweathered rock exposures in the field, specimens were wrapped in newspaper.

(2) Samples were then dry stored until ready for maceration.

(3) Rock samples were subsequently split/washed/scrubbed/crushed. Relatively poorly lithified siltstones were sometimes disaggregated by shaking in water and organic residues concentrated by filtering through $250 \mu \mathrm{m}$ polyester mesh. Adhering sediment was subsequently removed by immersing the organic fragments in HF for 24 hours and the $\mathrm{HCl}$ treatment omitted.

(4) Crushed specimens were then treated with concentrated technical reagent grade $\mathrm{HCl}$ for 24 hours.

(5) This was poured away and the beaker filled with water.

(6) Following a further decant, concentrated (40\%) technical reagent grade $\mathrm{HF}$ was added.

(7) The sample was stirred daily, adding more HF if any undigested pieces of rock were still present.

(8) Once samples were sufficiently broken down, usually after two days, the HF was decanted and the beaker filled with water.

(9) The residues were repeatedly washed with water until the $\mathrm{pH}$ reached 4 (on $\mathrm{pH}$ test strip), usually within five to six changes.

(10) Larger fragments were concentrated by washing through a $250 \mu \mathrm{m}$ or larger polyester mesh and checked with a stereomicroscope and then subjected to a second HF treatment ( 24 hours) to remove any adhering sediment still present.

(11) If the smaller size fraction was required $(<100 \mu m)$, a heavy mineral separation was employed using sodium polytungstate solution with a specific gravity of 2.0 .

(12) Specimens were finally washed with water and transferred to a petri dish for air-drying or into vials of $5-10 \% \mathrm{HCl}$ for storage.

\section{Analytical techniques}

Scanning electron microscopy. Macerates were examined using a stereomicroscope and suitable specimens were selected, picked up using a fine paintbrush and mounted on sticky $\mathrm{C}$ tabs attached to stubs and then coated with gold/palladium (some older stubs were re-examined and they had originally been coated with plain gold). They were examined using a FEI (Philips) XL30 (Environmental Scanning Electron Microscope with Field Emission Gun (ESEM FEG)) at an accelerating voltage of $20 \mathrm{kV}$. Imaging used a secondary electron detector (SE) and a backscatter electron detector (BSE). Elemental analyses were performed using an Oxford Instruments INCA ENERGY X-ray microanalysis system (EDX). Elements above atomic number 6 (C) were analysed, the results normalized and expressed as weight percentage (wt. \%). However, these chemical analyses can be regarded only as qualitative. The approach was to use the energy-dispersive approach on the FE-SEM and to analyse both the microbioid and background (substrate). Although the FESEM has a very fine analytical beam, well within the size of the microbioids, the beam samples a volume of sample which is greater than that of the microbioid and includes the background material. The depth of penetration and dispersal cannot be predicted or controlled, but is certainly greater than $1 \mu \mathrm{m}$ (see also Douglas \& Douglas 2000). The surfaces of the microbioids and background are not planar or perpendicular to the beam. Thus the counts collected are some fraction of the total counts for any element. Because of the irregularities of the surface, the analysed counts cannot be compared with standards and thus the conversion of counts to wt. $\%$ analyses is made by an internal generic algorithm.

The algorithm also normalizes the analyses to $100 \%$. In this normalization process various assumptions are made about the nature of the analyte including, for example, the nature of the $\mathrm{C}$-containing material (carbonate, oxide, silicate, etc.). Only analyses with a high $(\geqslant 30 \%)$ deadtime $\equiv 4$ kcps were collected in order to minimize the uncertainty. This means that the method probably collected at least $80 \%$ of the totals. Even so, the analyses of the microbioids can only be used to indicate the presence of elements and comparisons with background (essentially recognition of elements restricted to microbioids) and as some gauge of their abundance. A noteworthy feature is that traces of $\mathrm{Cl}$ characterize all spectra from Silurian specimens processed in Manchester. This probably relates to prolonged storage in $\mathrm{HCl}$ such that chloride ions remain even after prolonged 
washing. $\mathrm{Cl}$ is thus ignored in Manchester Silurian spectra. The sporadic occurrence of $\mathrm{Al}$ and $\mathrm{Cu}$, throughout the specimens, usually in trace amounts, has also been discounted as such elements probably derived from the residual sediment and use of tap water for washing. Unfortunately, our notes do not specify the purity of water used to extract material for biodiversity studies. Five workers were involved in the extraction processes over the years and precise extraction methodologies are not available and were not considered relevant as we were studying gross morphology rather than chemical composition. The 48 specimens from more than 12 macerations and three localities re-examined in this study (Appendix C) represent less than $2 \%$ of all mesofossil specimens examined by SEM in Cardiff, so what we noted at the time as bacterial contamination was not significant enough to warrant modifying our gross extraction techniques. For our biodiversity studies we mainly used lower magnifications (routinely up to $2000 \times$, maximum $10000 \times$ ) due to the resolution of the SEM available at the time. In this study with the increased resolution of the FE-SEM, magnifications of up to $50000 \times$ were routinely utilized. Some of the stubs are more than 20 years old and had been coated with a thick layer of gold (following several phases of splitting and re-examination in the SEM). This increases the size of the microbioids making them start to approach the size of bacteria. It also reduces the response from the other elements detected during analysis. In many cases, the gold coating had deteriorated with time, often showing cracking, causing problems with resolution at high magnifications. Over 20 new specimens were examined for this project and they were given much thinner gold/palladium coats ( 30 seconds) to enable more accurate analyses and higher resolution imaging. These specimens have (BP) as part of the stub number. Ideally, the new specimens should have been coated with $\mathrm{C}$ for analysis but, as we were interested in the amount of $\mathrm{C}$ present and we were comparing them with old specimens that had previously been coated with gold, we used a gold/ palladium coating. If gold and palladium counts are included in the analyses these sometimes account for as much as $66 \%$ of the totals.

Transmission electron microscopy. Pieces of selected specimens were removed from stubs, treated with fuming $\mathrm{HNO}_{3}$ (if an abundance of pyrite was present), rinsed with water and then embedded in molten $1 \%$ agar. This was used for support as the pieces were very small and could easily be lost during the TEM processing procedure. Once the agar had set, suitable sized blocks surrounding the specimen were cut out and were then dehydrated in acetone and infiltrated with Spurr resin by means of a graded acetone/Spurr resin series $(3: 1 ; 1: 1 ; 1: 3 ; 100 \%$ Spurr resin) (Spurr 1969) and transferred to $100 \%$ Spurr resin in moulds and polymerized. Embedded material was sectioned at approximately $70 \mathrm{~nm}$ by means of glass knives using an ultramicrotome. Sections were 'stretched' by exposure to chloroform vapour, collected on uncoated copper grids, stained with uranyl acetate and lead citrate (Reynolds 1963) and then examined in a JEOL 1210 TEM at an accelerating voltage of $80 \mathrm{kV}$.

$\mathrm{X}$-ray microanalysis at TEM level, although conducted, was not productive as the instrument was less sensitive than the SEM.

\section{Extant bacteria}

To explore the possibility that some of the microbioids we were investigating were modern bacterial contaminants, we applied the following procedures.

(1) Exposed coalified macerates to:

(a) unsterilized water;

(b) bacterial cultures.

(2) Conducted a comparative FE-SEM study on eu- and cyanobacterial cultures.

(1a) Samples from a Lochkovian macerate (locality 3, see Specimens section), which had been stored dry, were placed in a glass petri dish to which tap water was added. The lid was replaced and the dish was left for six weeks on a window sill during which time the lid was occasionally lifted to allow some contact with the atmosphere. The dish contents had almost dried out after six weeks and the lid was then left off until dried fully. Some of the samples were then removed, mounted on stubs, coated with gold/palladium and examined by FE-SEM, and the dried surface of the petri dish was also coated with gold/palladium and scanned. This was later re-scanned after a further two weeks and then another seven weeks. The remainder of the macerate was stored dry as a control and at the end of the experiment some specimens were selected at random and also mounted on stubs, coated with gold/palladium and examined by FE-SEM to see if any bacteria were present on the original macerate.

(1b) Several samples from a Př́ídolí macerate (locality 1) which had been stored dry, were split into two pieces. One piece from each sample was placed in a cocktail of soil bacteria (see 2a) in microtiterplates, sealed with parafilm and placed in a damp box in semi-darkness for six months. They were then removed from the culture and placed in $10 \%$ formalin for 48 hours, thoroughly rinsed with water, airdried, mounted on stubs, coated with gold/palladium and examined by FE-SEM. The other piece of each specimen was kept dry as a control and stored in an individual vial. After six months these pieces were also mounted on stubs, coated with gold/palladium and examined by FE-SEM.

(2a) Coccoid bacteria were cultured by Dr Henrik Sass (Cardiff University) from a soil sample taken from a fresh molehill (free of vegetation and roots, representing a relatively undisturbed soil community). About a gram of soil was added to $150 \mathrm{ml}$ of medium in a $500 \mathrm{ml}$ Erlenmeyer flask sealed with a foam stopper and aluminium foil. The medium formulated to enrich cellulose-degrading bacteria is shown in Table 1.

The $\mathrm{pH}$ of the trace element solution, made up after Tschech \& Pfennig (1984) was adjusted to 6.0 by the addition of $1 \mathrm{M} \mathrm{NaOH}$. After two weeks of incubation on a shaker at $25^{\circ} \mathrm{C}$ in the dark, the culture became turbid but was found to contain high numbers of Protozoa. To remove these, a 
Table 1. Composition of the culture medium for enrichment of cellulose-degrading bacteria

\begin{tabular}{lcc}
\hline $\begin{array}{l}\text { Component (all analytical } \\
\text { grade except cellulose) }\end{array}$ & pro 1 Medium & Concentration \\
\hline Distilled water & $950 \mathrm{ml}$ & $55.5 \mathrm{M}$ \\
K-phosphate buffer, pH 7.0, 1.0 M & $50 \mathrm{ml}$ & $50 \mathrm{mM}$ \\
$\left(\mathrm{NH}_{4}\right)_{2} \mathrm{SO}_{4}$ & $1.06 \mathrm{~g}$ & $8 \mathrm{mM}$ \\
$\mathrm{MgSO}_{4}$ & $0.10 \mathrm{~g}$ & $0.4 \mathrm{mM}$ \\
$\mathrm{CaCl}_{2} \times 2 \mathrm{H}_{2} \mathrm{O}$ & $0.03 \mathrm{~g}$ & $0.2 \mathrm{mM}$ \\
$\mathrm{Na}$ lactate $(50 \%)$ & $0.1 \mathrm{ml}$ & $0.6 \mathrm{mM}$ \\
Trace element solution SL9 & $1 \mathrm{ml}$ & \\
Cellulose powder & $2 \mathrm{~g}$ & \\
\hline
\end{tabular}

series of successive dilutions were prepared and incubated for a further two weeks. The resulting culture was used in experiment $1 \mathrm{~b}$ and some was also centrifuged to concentrate the bacteria, thoroughly washed, air-dried onto stubs, coated with gold/palladium and examined by FE-SEM. The stubs were subsequently re-examined by FE-SEM after four months. All handling of media and bacterial cultures was done in a microbiological cabinet to avoid contamination.

(2b) Samples from cultures of the nostocalian cyanobacteria, Pseudoanabaena catenata and Plectonema boryanum (obtained from SAMS Research Services Ltd., Dunstaffnage Marine Laboratory, Dunbeg, Oban, PA37 1QA) were washed and then air-dried onto thermanox coverslips on stubs, coated with gold/palladium and examined by FE-SEM with EDX. The same stubs were then stored for three weeks and scanned again.

\section{Results}

For convenience of description, the microbioids are grouped first on shape (e.g. spheres, rods, filaments) and then within each category, where subdivision is based on size, surface features and on chemical characterization.

\section{CATEGORY 1 - Spheres}

Category 1a. clumped spheres $<0.1 \mu \mathrm{m}$ diameter; $\mathrm{Si}$ signature (Fig. 1(a)-(f))

Preparation. Standard HF extraction techniques in Manchester, all from the same batch, $\mathrm{HCl}$ stored (see Appendix A).

Substrates. Př́idolí, Ludford Lane (LL). Disintegrating flattened discoidal sporangium with fragments of border and in situ spores (LL26/3), oval spore mass of Laevolancis divellomedia with typical 'holes' (LL29/6), fragment of curved apex of sporangium with discrete margin and Laevolancis divellomedia (LL30/1).

Microbioids. Very abundant spheres, sometimes clustered and in mounds, completely covering spore and sporangium surfaces (Figs 1(b) and (c)) sometimes more dispersed (Fig. 1(a)). Many are not perfect spheres because their surfaces are irregular. The average diameter was $0.07 \mu \mathrm{m}$, the minimum $0.03 \mu \mathrm{m}$ and the maximum $0.1 \mu \mathrm{m}$ (detailed dimensions are presented in Appendix B Categories 1(a)-(g), bacteria (i)). They were amongst the smallest structures analysed.

TEM. Sections show spores and sporangium wall (Figs 1(d)-(f)). Spheres are not restricted to exposed surface. They occur on voids within the spore mass (Fig. 1(f)), but not on the adpressed surfaces of the compressed spores, i.e. they are not part of the exospore or perispore. They are homogeneous in composition (Fig. 1(d)).

Chemistry. (See Appendix C.) The maximum amount of silica recorded in any analysis was 15wt. \% (LL29/6). LL30/1 is unique in that increased levels of $\mathrm{Cl}$ are accompanied by similar increases in $\mathrm{Na}$.

Interpretation. The small size of the microbioids $<0.1 \mu \mathrm{m}$ diameter (towards the lower limits of nanobacteria) augurs against a bacterial origin. The most significant chemical differences between the spore/sporangium background and microbioid relate to increased concentration of $\mathrm{Si}$ in the latter with inference that these are silica-rich $\left(\mathrm{SiO}_{2}\right)$ spheres. Their smooth surfaces indicate chemical synthesis/precipitation rather than incomplete digestion. It is suggested that $\mathrm{Si}$ was dissolved in the HF treatment and locally reprecipitated on washing and drying. Indeed the particles resemble those synthesized for nanotechnology, and the extraction process is reminiscent of the (far more controlled) methods used to produce monodispersed silica spheres. All examples came from the same batch and although one specimen shows silica only on one surface, it is assumed that the precipitate was produced during extraction. While it is possible that the coalified surfaces acted as nucleation sites, the possibility that the spheres are organosilicates cannot be discounted. In Fig. 1, a Si-rich precipitate covers a Ti-rich rod.

Category 1b. 'Perfect' smooth spheres $<0.5 \mu \mathrm{m}$ diameter; Si signature (Figs 1(g)-(l), 4(k))

Preparation. Standard HF extraction techniques in Manchester, all from the same batch, $\mathrm{HCl}$ stored (see Appendix A).

Substrate. Six specimens from the Prídolí at Ludford Lane. These comprise three axes (two with stomata (LL49/2, LL51/4), one twisted (cf. Hollandophyton, LL50/5)), two unidentifiable sporangia with certain areas revealing spores (one type smooth walled (LL38/1), the other with a marked granular ornament on all surfaces except contact areas (LL38/2) Fig. 1(k)). Mass of degraded, fine tubes (LL38/3).

Microbioid morphology. Spheres show a narrow size range. The average diameter was $0.4 \mu \mathrm{m}$, the minimum $0.1 \mu \mathrm{m}$ and the maximum $0.5 \mu \mathrm{m}$ (detailed dimensions are presented in Appendix B Categories 1(a)-(g), bacteria (i)). They are larger 

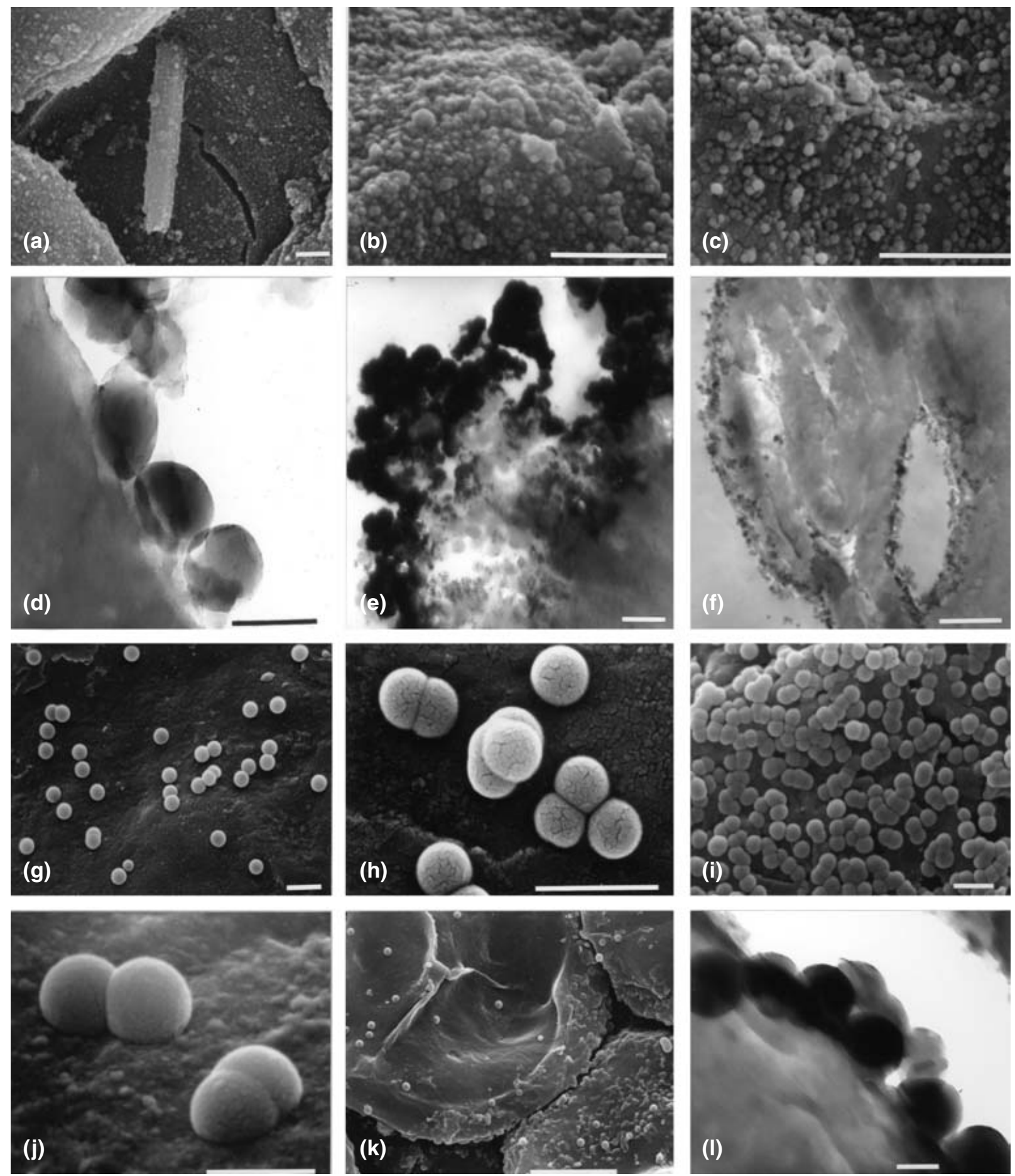

Fig. 1. Silica spheres on Př́idolí mesofossils from Ludford Lane (LL). (a)-(f) Category 1a. (a)-(c) SEMs, scale bars =1 $\mu \mathrm{m}$ : (a) LL29/6, note rod rich in Ti (Category 2a) coated with Si precipitate; (b) LL30/1; (c) LL26/3. (d)-(f) TEMs, LL26/3: (d), (e) scale bars=0.1 $\mu \mathrm{m}$; (f) scale bar $=0.5 \mu \mathrm{m}$. Black areas in (e) are the gold coating. Note precipitate in void in (f). (g)-(l) Category $1 \mathrm{~b}$, smooth surfaces, all SEMs except (1). (g) LL50/5, scale bar=1 $\mu \mathrm{m}$; (h) LL49/2, scale bar=1 $\mu \mathrm{m}$; (i) LL38/3, scale bar =1 $\mu \mathrm{m}$; (j) LL49/2, scale bar=0.5 $\mu \mathrm{m}$; (k) surfaces of spores, distal faces with ornament, LL38/2, scale bar $=5 \mu \mathrm{m}$; (1) TEM, LL38/2, scale bar $=0.1 \mu \mathrm{m}$.

than in category la and may be scattered over the surface of the substrate in varying densities (cf. Figs $1(\mathrm{~g})$ and (i)) in one case producing a 'polygonal' sheet. Occasionally they occur in pairs or threes (Figs 1(h) and (j)), with flat contact faces or in small clusters that may sometimes be (perhaps fortuitously) aligned in chains of four. The area of contact with the substrate also varies such that some appear almost hemispherical.

TEM. Sections were made of the sporangium with ornamented spores (Fig. 1(k)), resulting in some confusion between the granular ornament and the spheres. The latter 
are recognized by their smooth outline, discreteness and homogeneous appearance (Fig. 1(1)). Ornament has similar size but is continuous with the exospore, slightly more granular in appearance and with a less well-defined outline.

Chemistry. (See Appendix C.) Some variation is recorded between the spectra but, with one exception, $\mathrm{Si}$ is recorded only on microbioids and not on spores or the sporangium wall. The maximum amount recorded in any analysis was 12 wt. $\%$ (LL38/2).

Interpretation. Dimensions are almost an order of magnitude greater than in category $1 \mathrm{a}$, and hence in size at least, these microbioids are comparable with bacteria. However, they are probably mainly composed of silica and are postulated to have a similar origin to category 1a types. Their increased size probably results from slightly different conditions in the extraction process. Indeed, all six specimens came from the same batch. They also differ from category $1 \mathrm{a}$ in that (with one exception) $\mathrm{Si}$ was not recorded in the substrate.

Category 1c. Spheres with minutely granular surfaces; less than $2.0 \mu \mathrm{m}$; Ca and F signature (Figs 2(a)-(1))

Preparation. Standard HF extraction techniques in Cardiff, all from the same batch (see Appendix A).

Substrate. Lochkovian, North Brown Clee Hill. Eight samples comprising cf. Salopella sp. (HD1/5), Resilitheca sp. (HD2/2), Cooksonia banksii (HD1/4), four fragments of indeterminate sporangia (HD2/3, HD2/4, HD3/1, HD5/2) and a superficial piece of Pachytheca (HD7/1).

Microbioids. Spheres occur on all exposed surfaces and may be isolated, in pairs, clusters or in chains forming filamentlike structures (Figs 2(c), (d) and (f)). All surfaces are granular (Fig. 2(e)). Those in pairs show straight contact lines, and may or may not be the same size. The 'filaments' have a more uniform diameter, and may be straight or curved (Figs 2(d) and (f)). They do not branch, but surfaces may bear individual or clusters of spheres (Figs 2(c) and (d)). Mean diameters of the spheres/sample are similar, but individual samples show a wide size range. The average diameter was $0.7 \mu \mathrm{m}$, the minimum $0.2 \mu \mathrm{m}$ and the maximum $2.0 \mu \mathrm{m}$ (detailed dimensions are presented in Appendix B Categories 1(a)-(g), bacteria (i)).

TEM. Recoating of the specimens has produced an abnormally thick 'black' layer of gold. Below or within this are roughly circular areas filled with resin (Fig. 2(1)), or a 'grainy' material (Figs 2(j) and (k)). The latter may fill the area or line a void. Figure 2(k) shows two uncoated examples with similar organizations. This raises the possibility, especially for those with resin infill, that the spherical structures were sometimes hollow, although in some of the latter the grainy material may have become displaced during sectioning.
In one specimen only, a rod-shaped translucent structure is surrounded by the grainy material (Fig. 2(i)).

Chemistry. (See Appendix C.) All EDX spectra of the microbioids show $\mathrm{Ca}$ and $\mathrm{F}$ in addition to $\mathrm{C}$. Background spores and sporangia show predominantly $\mathrm{C}$ and $\mathrm{O}$. Where microbioids contain $\mathrm{Fe}$, this is also seen on the substrate. Analysis of TEM sections revealed $\mathrm{Ca}$, but only trace amounts of $\mathrm{F}$.

Interpretation. All these specimens, although initially examined at different times, came from the same preparation batch. It is therefore concluded that the spheres are a $\mathrm{CaF}_{2}$ precipitate, although the presence of $\mathrm{C}$ in the microbioids raises the possibility that organic material formed a surface for nucleation of $\mathrm{CaF}_{2}$. However, treatment by boiling in $\mathrm{HCl}$ (that removed $\mathrm{CaF}_{2}$ ) and subsequent washing, left no coalified residues. Hence, the detection of $\mathrm{C}$ in the microbioid probably resulted from the inclusion of substrate $\mathrm{C}$ in the analysis.

Category 1d. Spheres with irregular pitted surfaces; Ca and F signature (Figs 3(a)-(d))

Preparation. Standard HF extraction techniques in Cardiff, all from the same batch (see Appendix A).

Substrate. Targrove Quarry, Lochkovian. Two small spore masses, with apiculate (T76/1); smooth (T76/8) sculpture. Contact features (e.g. triradiate marks) not seen.

Microbioids. Isolated (Fig. 3(a)) or small clusters of spheres (Fig. 3(d)) with pitted surfaces are distributed over all exposed surfaces, sometimes in depressions. Clustered examples on T76/1 are associated with fragmentary smooth sheets. Examples that appear to merge into the spore surface may result from deterioration during stub storage. Rare examples of smooth spheres show a central depression, perhaps indicating a hollow structure. This raises the possibility that the ornament is not surface pitting but formed from very regular close-set granules with flattened outer surfaces. There is some variation in 'granule' size between spheres. The average diameter was $0.7 \mu \mathrm{m}$, the minimum $0.3 \mu \mathrm{m}$ and the maximum $1.2 \mu \mathrm{m}$ (detailed dimensions are presented in Appendix B Categories 1(a)-(g), bacteria (i)).

TEM. Only a few sections were obtained from T76/8 and are similar to those illustrated for category 1e (Figs 3(j) and $(\mathrm{k}))$.

Chemistry. (See Appendix C.) When compared with the microbioids with granular surfaces and showing predominantly $\mathrm{Ca}$ and $\mathrm{F}$ (category $1 \mathrm{c}$ ), these spectra contain a wider range of elements $(\mathrm{Na}, \mathrm{Al}, \mathrm{Si}, \mathrm{Cl})$, and there is considerable variation between the microbioids and background.

Interpretation. Probable precipitate of $\mathrm{CaF}_{2}$, but additional elements may point to one or more complex minerals. 

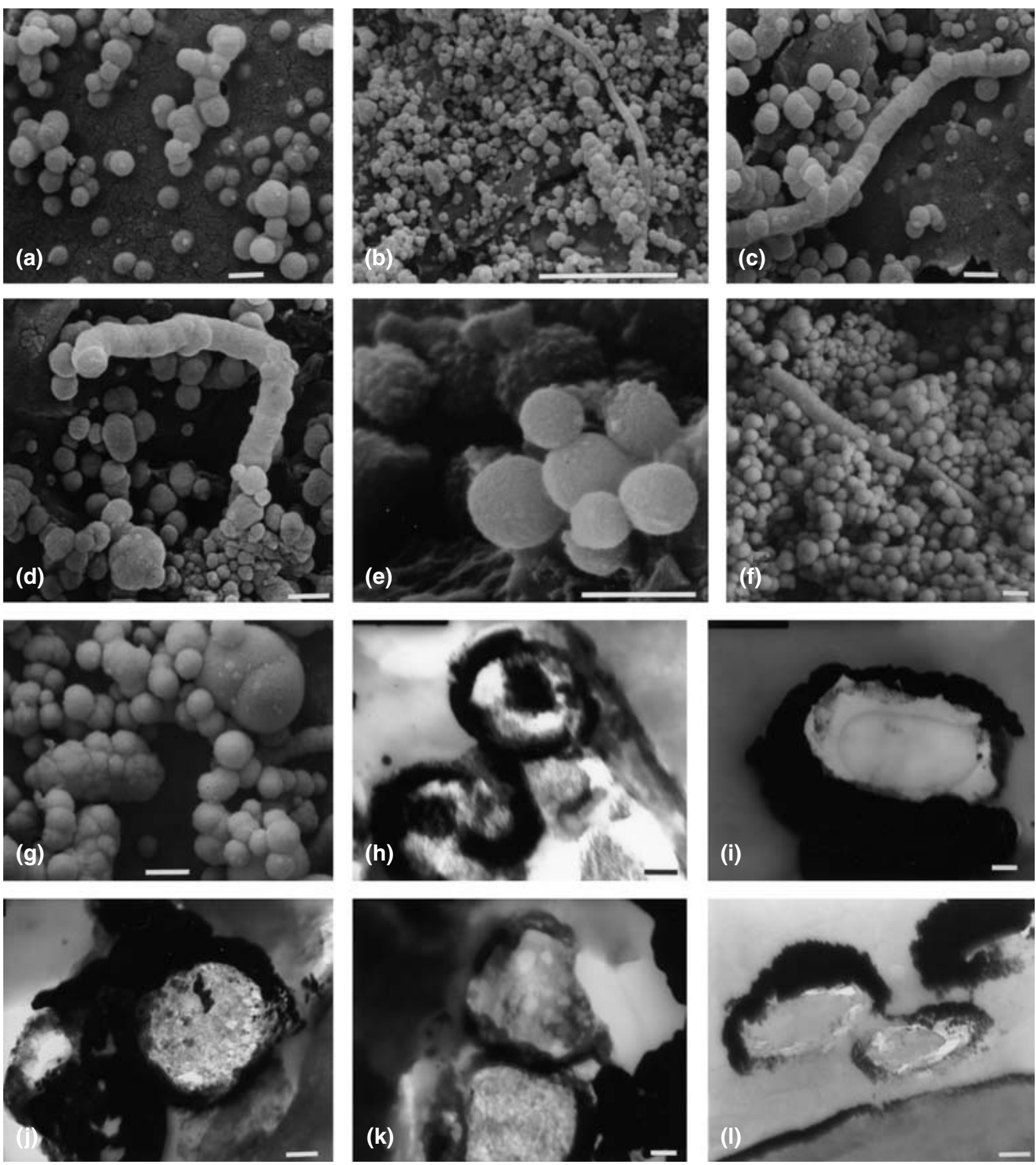

Fig. 2. $\mathrm{CaF}_{2}$ spheres on Lochkovian mesofossils from North Brown Clee Hill (HD). Category 1c, minutely granular surfaces. (a)-(g) SEMs. Scale bars $=1 \mu \mathrm{m}$, except (b) where scale bar $=10 \mu \mathrm{m}$. (h) $-(\mathrm{l})$ TEMs. Scale bars $=0.1 \mu \mathrm{m}$. The dark areas are the gold coating.

(a)-(c) HD1/5; (d) HD1/4; (e) note distinctive surface with framboidal sphere type (Category 1f) in background, HD5/2; (f), (g) HD2/2;

(h)-(k) HD1/5. Note rod-shaped structure in (i), more coarsely granular periphery in (k). (l) HD2/2, centres filled with resin.

Category 1e. Isolated spheres or clusters with pronounced irregular surfaces ('cauliflower type'); $\mathrm{Ca}$ and $\mathrm{F}$ signature (Figs 3(e)-(k))

Preparation. Standard HF extraction techniques in Cardiff, but from two batches. HD6/1 was in the same batch as category 1c (see Appendix A).
Substrate. Lochkovian, North Brown Clee Hill. Fragment of sporangium of Sporothylacium salopense (HD6/1), longitudinally fractured Cooksonia pertoni ssp. aneurospora with stalk (HD(UF)103/5).

Microbioids. Some are isolated spheres (Fig. 3(h)), but majority form irregular clusters (e.g. Fig. 3(g)), with surface 
ornament ranging from uniform to very irregular (Figs 3(e)(i)) as is seen on clusters on the outside of the Sporathylacium sporangium wall (Fig. 3(g)). They are linked in some cases to form multiseriate chains (Fig. 3(h)) or by amorphous strands (Fig. 3(i)). By contrast, when the sporangium was split open the spheres are more isolated with granular surfaces (Fig. 3(f)). Measurements were concentrated on the discrete elements. The average diameter was $0.7 \mu \mathrm{m}$, the minimum $0.4 \mu \mathrm{m}$ and the maximum $1.0 \mu \mathrm{m}$ (detailed dimensions are presented in Appendix B Categories 1(a)-(g), bacteria (i)).

TEM. More or less circular (Fig. 3(j)) to lobed with a grainy appearance, that is further resolved into small discs (Figs 3(j) and $(\mathrm{k})$ ). The latter may account for the irregular topography of the clusters. Dispersed examples occur in the resin outside the sporangium wall.

Chemistry. (See Appendix C.) Spectra of the clusters are very simple with $\mathrm{C}, \mathrm{Ca}$ and $\mathrm{F}$. The lowest values of $\mathrm{C}$ were recorded in this broad category, but this may reflect the relatively high relief of the clusters. $\mathrm{C}$ and $\mathrm{Ca}$ dominate the spore. Surprisingly, some of the clusters lack F (HD(UF)103/5), possibly due to a thick gold coat.

Interpretation. Again precipitation of $\mathrm{CaF}_{2}$ during preparation, but minor differences in micromorphology may result from variations in the depositional environments inside and outside the sporangium, as the size and nature of the crystals could be affected by diffusion gradients (hence supply of ions) between the exterior and the interior of the sporangium.

Category 1f. Spheres with pronounced framboidal surfaces; no significant chemical signature (Figs 2(e), 3(1)-(p))

Preparation. Standard HF extraction techniques in Cardiff (two batches of Lochkovian specimens from North Brown Clee Hill) and Manchester (several pooled batches of Př́dolí specimens from Ludford Lane, $\mathrm{HCl}$ stored) (see Appendix A).

Substrate. Within sporangia of Lochkovian Resilitheca (HD2/2; HD5/2; HD65/1) and Př́dolí indeterminate, incomplete, cup-shaped sporangium (LL(BP)5/4).

Microbioids. Occur in clusters between spores (Figs 3(1) and (n)), isolated or adhering in sheets (Fig. 3(m)) over spore surfaces. Devonian examples have a well-defined framboidal appearance with ornament almost biform (using spore terminology: Fig. 3(1)). Smaller spheres with irregular surfaces represent features of the exospore (left-hand side of Fig. 3(1)). Brighter spheres in Fig. 3(m) are composed of $\mathrm{CaF}_{2}$. Silurian examples are smaller, less frequent and with a less welldefined ornament which may be similar to that on the surface of a spore. The average diameter was $0.83 \mu \mathrm{m}$, the maximum $1.4 \mu \mathrm{m}$ and the minimum $0.3 \mu \mathrm{m}$ (detailed dimensions are presented in Appendix B Categories 1(a)-(g), bacteria (i)).
TEM. Ultrastructure demonstrating composite nature of the framboids, illustrated by Edwards et al. (1995) in Resilitheca, is confirmed here (Fig. 3(o)), but the Silurian examples are homogeneous in section with only slightly irregular topography (Fig. 3(p)).

Chemistry. (See Appendix C.) The 'framboids' usually show remarkable similarities with spectra of the sporangia and spore walls, even in the presence of certain minor elements (e.g. Fe and $\mathrm{Cu}$ in $\mathrm{HD} 2 / 2$ ) and are therefore assumed to be of organic origin.

Interpretation. Similarities in chemistry suggest an organic origin for the 'framboids'. Earlier researches investigating spore ultrastructure and development in Resilitheca had led to the hypothesis that these framboidal structures were related to exospore development, perhaps illustrating the remnants of a secretory tapetum at the end of sporopollenin deposition. Similar structures were reported in Sawdonia acanthotheca (Gensel 1980) and Sporothylacium (Edwards et al. 1995) and were thought to have the same origin. Their predominantly organic nature and similarities with the exospore surface further support their biological nature, especially as other globules and rods on the same spores/ sporangia demonstrate a partial mineral composition. Previously documented examples have very sculptured surfaces that are rather different to specimens in Fig. 3. Ornamented surfaces do not exclude spheres being bacterial, as gram-negative bacteria have an extra outer layer (LPS) with an ornamented/textured surface. However their constant presence in named plant megafossils favours their intrasporangial developmental origin.

Category 1g. Smooth irregularly shaped but predominantly globular structures (Fig. 6(1))

Preparation. Standard HF extraction techniques in Manchester, all from the same batch, $\mathrm{HCl}$ stored (see Appendix A).

Substrate. Přídolí (Ludford Lane) irregularly shaped spore mass with laevigate indeterminate spores (LL12E) and a Laevolancis divellomedia spore mass (LL6/6).

Microbioids. Microbioids with predominantly smooth surfaces: some with outgrowths (double arrow in Fig. 6(1)). A relatively wide size range: the average diameter was $0.7 \mu \mathrm{m}$, the maximum $1.5 \mu \mathrm{m}$ and the minimum $0.2 \mu \mathrm{m}$ (detailed dimensions are presented in Appendix B Categories 1(a)-(g), bacteria (i)). Many merge into the substrate and each other. They are associated with granular material and very narrow elongate rods or strap-shaped structures, the latter closely adhering to the spore wall (small arrow in Fig. 6(1)).

\section{TEM. None}

Chemistry. (See Appendix C.) Limited evidence indicates that the microbioids have a similar composition to the 

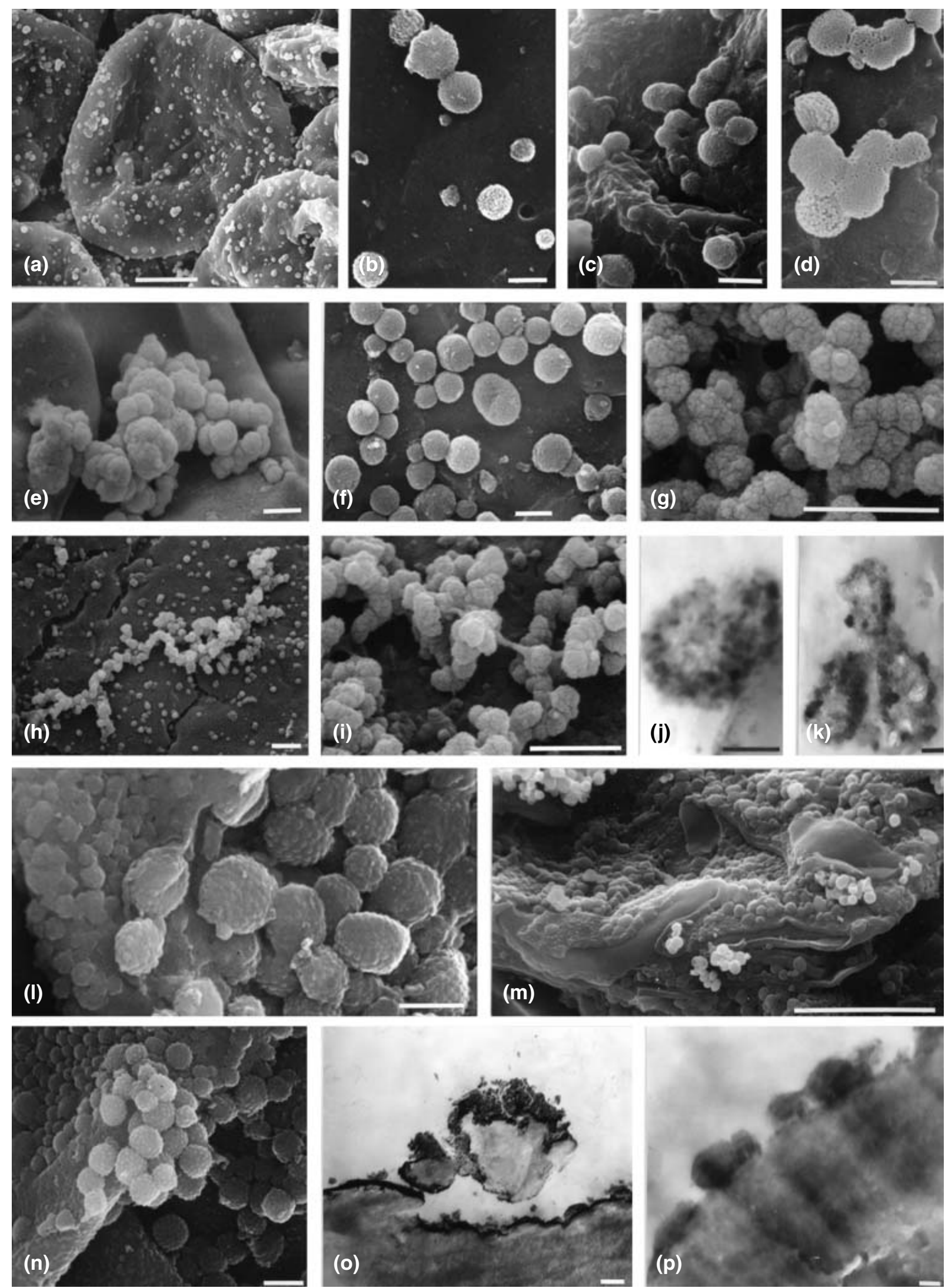

Fig. 3. (a)-(p) Spheres on Lochkovian mesofossils from (a)-(d) Targrove (T); (e)-(o) North Brown Clee Hill (HD). (p) on Přídolí mesofossils from Ludford Lane (LL). (a)-(d) Category 1d, irregular 'pitted'surfaces, all SEMs. (a), (b) T76/8: (a) isolated spheres on spore surfaces, scale bar $=10 \mu \mathrm{m}$; (b) scale bar $=1 \mu \mathrm{m}$. (c), (d) T76/1: scale bars $=1 \mu \mathrm{m}$; (d) clusters of spheres with 'ornament' of variable size. (e)-(k) Category 1e ('cauliflower' type), all HD6/1 except (e) HD(UF)103/5: (e)-(i) SEMs, scale bars = $1 \mu \mathrm{m}$, note variation in arrangement of 
underlying spore wall, although apart from $\mathrm{C}, \mathrm{O}$ and $\mathrm{Na}$, most elements are present in trace amounts. The narrow elongate rod (* in Fig. 6(1)) is titanium-rich (category 2a).

Interpretation. These 'spheres' show greater variability in form and size than the mineralized structures described so far. The lack of Si detection in these analyses is significant, since it suggests that silicon-based materials (e.g. $\mathrm{SiO}_{2}$, silicates) are absent, and that $\mathrm{Na}, \mathrm{K}, \mathrm{Ca}$ and $\mathrm{O}$ are not contained in silicate minerals. There is a lack of any anions in the analysis except $\mathrm{O}$, which might suggest oxides. Carbonate is improbable because of the low $\mathrm{Ca}$ counts and prior acid treatment. $\mathrm{Cl}$ is low, and therefore, $\mathrm{Na}$ and $\mathrm{K}$ do not result from salt being formed as an artefact of the treatment. These negative observations suggest that these forms are organic and, together with their chemical compositions, suggests a biological origin, with a possibility that they were fossilized at the same time as the spores. The narrow strap-shaped structures are similar to filamentous bacteria including possible actinomycetes, but are very small.

\section{CATEGORY 2-Rod shaped structures}

Category 2a. Greater than four times as long as wide; titanium signature (Figs 1(a), 4(a)-(k), 6 (h) and (l) and 7(b))

Preparation. Standard HF extraction techniques in Manchester (three individual batches plus one pooled batch of Prrídolí specimens, $\mathrm{HCl}$ stored) and Cardiff (one batch of Prrídolí specimens and three batches of Lochkovian specimens) (see Appendix A).

Substrates. Present on macerals from both Prídolí, Ludford Lane and Lochkovian, North Brown Clee Hill localities. Přídolí examples include discoidal and elliptical spore masses with Laevolancis divellomedia (LL(A)2/3, LL11D, LL29/6), Hollandophyton (LL(BP)2) and indeterminate sporangia (LL6/6, LL12E, LL38/1, LL38/2, LL(BP)5/4), with rods on surfaces of spores and sporangial wall; collections of nematophyte tubes (LL38/3). Lochkovian examples include reniform sporangia of Resilitheca salopensis (HD(UF)216B/3, HD2/2), Sporathylacium salopense (HD6/1) and unidentified sporangia (HD2/4, HD3/1, HD5/2) containing apiculate and shagrinate spores, a fragment of Pachytheca (HD7/1), smooth (HD450/1) and papillate (HD450/2) cuticle of nematophyte type.

Morphology. Single, rare, rod-shaped structures show a range in morphology, but are never collapsed, and are always at least four times longer than wide. There is variation in length to width ratio, the latter falling into a comparatively small size range, such that some appear almost acicular (Figs 4(b) and (g)). Length 0.63-8.6 $\mu \mathrm{m}$ (average $=2.82 \mu \mathrm{m})$, width $0.06-1.23 \mu \mathrm{m}$ (average $=0.43 \mu \mathrm{m})$ (detailed dimensions are presented in Appendix B Categories 2(a)-(c)). Rods are parallel-sided, and present either a smooth, 'clean' or slightly granular appearance. Ends may be rounded (Figs 4(b) and (h)) or abruptly truncated (Fig. 4(d)): the fractured surfaces of the latter show a homogeneous composition (Fig. 4(e)). Rare examples show a depression of similar size or shape on spores below the rod (Fig. 4(h)) or remaining after the rod has presumably been displaced (Fig. 4(c)). Figure 4(k) shows an example of a rod projecting from the fossil surface. Some Lower Devonian specimens are covered in numerous, small spherical structures (Fig. 4(f)).

TEM. Rarity prevented location of microbioids on sectioning.

Chemistry. (See Appendix C.) In all examples, titanium is confined to the rods and signatures are usually dominated by $\mathrm{C}$ and $\mathrm{O}$. The maximum amount of titanium measured in any analysis was $47 \mathrm{wt}$. \% (HD5/2). Other elements in common are calcium, sodium and chlorine.

Interpretation. It seems likely that the rod-shaped structures are rutile $\left(\mathrm{TiO}_{2}\right)$. In contrast, the spheres on the same Lochkovian specimens are dominated by calcium and fluorine (Figs 4(a)-(d) and (f)) and the Přídolí examples by silica (Fig. 4(k)). While the $\mathrm{C}$ signature probably reflects depth of the beam extending into the substrate, it is of course possible that the rod-shaped structures were originally bacteria that acted as a template for mineral deposition which then replaced the organic material. This seems unlikely as rutile is a detrital mineral not uncommon in sedimentary rocks (Deer et al. 1966).

Category 2b. Less than four times as long as wide (Figs 4(1)-(n))

Preparation. Standard HF extraction techniques in Manchester (one pooled batch of Př́dolí specimens from Ludford Lane, $\mathrm{HCl}$ stored) and Cardiff (one batch of Lochkovian specimens from North Brown Clee Hill) (see Appendix A).

Substrate. Př́dolí smooth probably arthropod cuticle (LL(BP)6/2); Lochkovian smooth walled spore mass (HD(UF)216A/10, ? Laevolancis (NMW96.30G.5, Wellman et al. 1998a)) associated with irregular sheets; coprolitecontaining spores and degraded 'stringy' tissue (HD(UF)216A/3).

spheres ((h) with isolated spheres and chains); (j), (k) TEMs, scale bars $=0.05 \mu \mathrm{m}$, sections indicating clusters of extremely small particles. (1)-(p) Category 1f, spheres with framboidal surfaces. (1)-(n) SEMs: (1) note contrast between presumed tapetal residues and ornament on spore wall (to left), HD65/1, scale bar $=1 \mu \mathrm{m} ;(\mathrm{m})$ fractured spores with tapetal residues attached to outer layer of exine and $\mathrm{CaF}_{2}$ spheres (white clusters), HD2/2, scale bar $=10 \mu \mathrm{m}$; (n) note variation in size of adhering spheres in contrast to the more uniform appearance of the spore ornament, HD5/2, scale bar $=1 \mu \mathrm{m}$. (o), (p) TEMs: (o) section, HD5/2, scale bar $=0.1 \mu \mathrm{m}$; (p) LL(BP) 5/4, scale bar $=0.1 \mu \mathrm{m}$. 

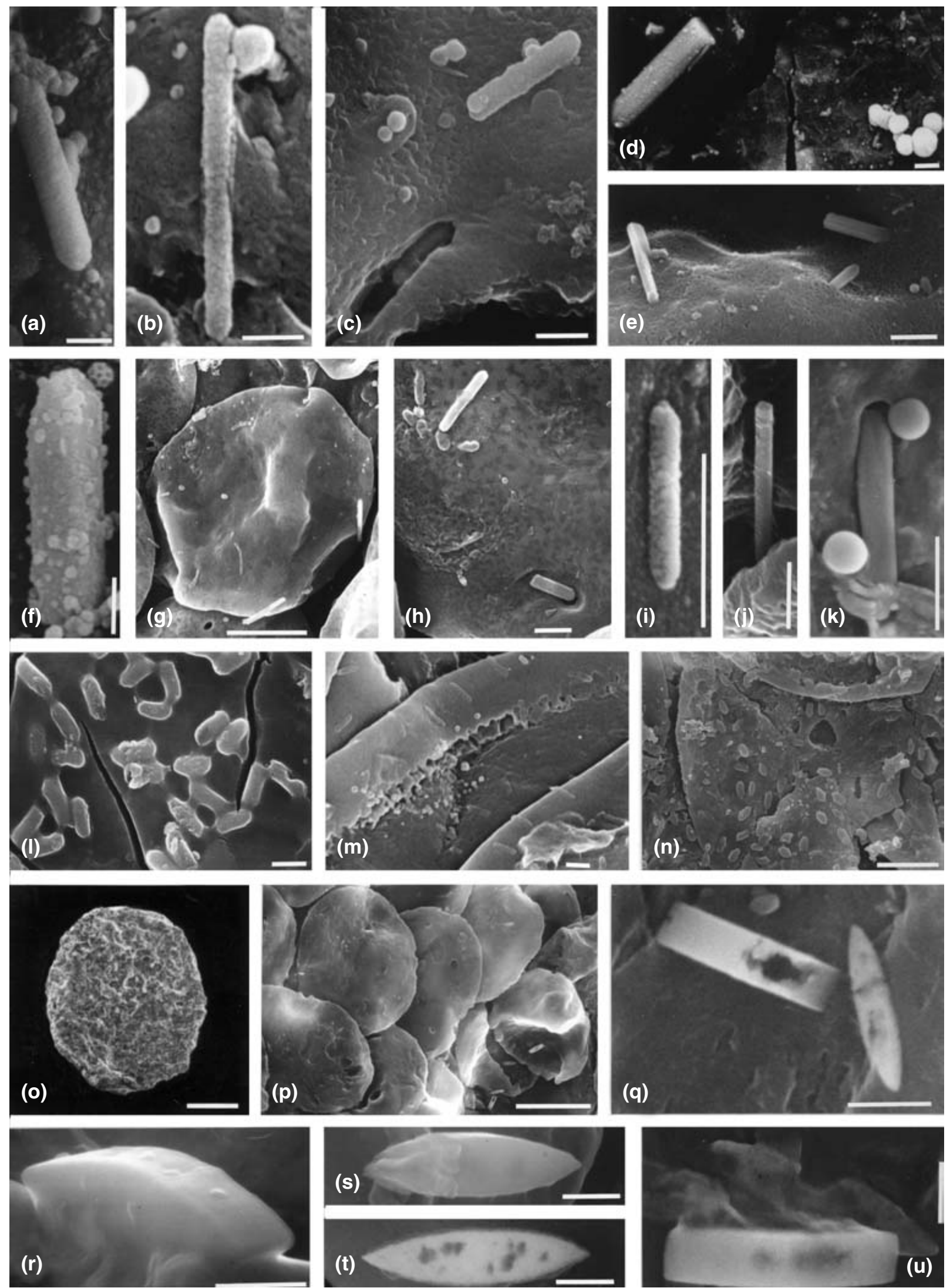

(q)

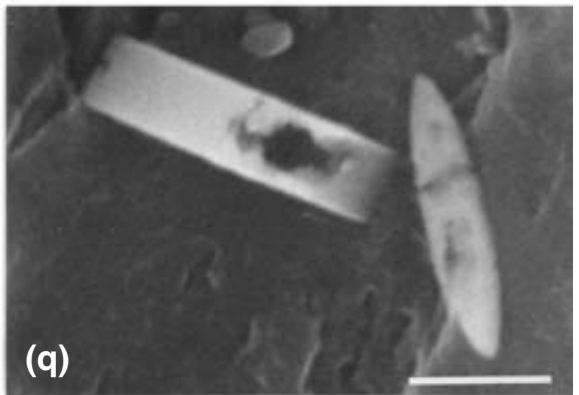

Fig. 4. Elongate microbioids on (a)-(f), (m) and (n) Lochkovian mesofossils from North Brown Clee Hill (HD), and (g)-(l) and (o)-(u) Př́idolí mesofossils from Ludford Lane (LL). (a)-(k) Category 2a, rods with titanium signatures, all SEMs, scale bars $=1 \mu \mathrm{m}$, except (g) where $=5 \mu \mathrm{m}$ : (a) HD2/2; (b), (c) HD3/1, note granular texture of surface in (a), and groove from which rod has been displaced in (c); 
Microbioids. Lochkovian specimens on surface of spores (HD(UF)216A/10) are rod-shaped (Fig. 4(m)). Length $1.0-2.0 \mu \mathrm{m}$ (average $=1.5 \mu \mathrm{m})$, width $0.3-0.4 \mu \mathrm{m}$ (average $=$ $0.3 \mu \mathrm{m})$. Other Lochkovian specimens also on spores (HD(UF)216A/3) are short and isolated (Fig. 4(n)) and of variable and sometimes irregular shape. Length 2.2-3.1 $\mu \mathrm{m}$ (average $=2.6 \mu \mathrm{m}$ ), width $1.1-1.4 \mu \mathrm{m} \quad$ (average $=1.2 \mu \mathrm{m}$ ). Př́idolí examples are of more uniform shape, varying mostly in length (Fig. 4(1)). Length $1.0-1.5 \mu \mathrm{m}$ (average $=1.2 \mu \mathrm{m}$ ), width $0.4-0.7 \mu \mathrm{m}$ (average $=0.5 \mu \mathrm{m})$ (detailed dimensions are presented in Appendix B Categories 2(a)-(c)). Many are isolated; some occur in pairs, usually associated end to end (Fig. 4(1)) with a continuum between adjacent elements. Some possess discrete outlines (Fig. 4(n)), but others merge into the substrate (Fig. 4(1)). Surfaces are usually smooth, but occasionally granular. The Prídolí arthropod cuticle was also characterized by rare silica-rich spheres.

TEM. For HD(UF)216A/10 only, but sections did not pass through any bacteria.

Chemistry. (See Appendix C.) Available only for the Př́dolí arthropod examples. The rods have the same chemical composition as the cuticles with $\mathrm{Cl}$ and $\mathrm{Ca}$ in addition to $\mathrm{O}$, with $\mathrm{C}$ consistently lower than $\mathrm{O}$, the latter unusual when compared with plant-derived mesofossils.

Interpretation. These rod-shaped structures in their size range and distribution resemble true bacteria. That they are probably extant contaminants is evidenced by their resemblance to the rod-shaped bacteria colonizing mesofossils and petri dish surface in our experimental work (Figs 9(a)-(f)). Those on the arthropod cuticle (Fig. 4(1)) appear to have a covering similar to a biofilm. However, evidence against recent contamination, particularly for the arthropod examples, are the chemical similarities (particularly proportions of $\mathrm{C}$ and $\mathrm{O}$ ) between substrate and microbioids.

Category 2c. Naviculate/rectangular forms (cf. diatoms) (Figs 4(o)-(u))

Preparation. Standard HF extraction techniques in Manchester (one pooled batch of Prrídolí specimens, $\mathrm{HCl}$ stored (see Appendix A).

Substrate. All Přídolí (Ludford Lane). Microbioids occur on three specimens, with most on a compressed almost circular spore mass $(735 \times 632 \mu \mathrm{m})$ practically completely enclosed by a thick layer lacking well-defined cells (Fig. 4(o), LL(BP)2/1). Its surface is irregular with voids and a 'flaky' appearance. Spores (Fig. 4(p)) are separated dyads assigned to Laeveolancis divellomedia Type A on the basis of their bilayered exospore revealed by TEM (Wellman et al. 1998a). Single examples were found on a mass of tubes (LL(BP)29/2) and an unidentified fragment (LL(BP)GT1, Fig. 4(t)).

Morphology. All specimens show either an elongaterectangular (Figs 4(q) and (u)) or naviculate outline (Figs 4(q)-(t)) being different aspects of the same threedimensional (3D) structures (Fig. 4(r)) (where rectangular means depth and naviculate is width). The latter specimen appears to be covered by an amorphous film continuous with the surface of the spore. The nine examples on $\operatorname{LL}(\mathrm{BP}) 2 / 1$ ) occur in clusters in different areas. Some were found on the outside of the sporangium, others on exposed spores. Length 1.7-2.2 $\mu \mathrm{m} \quad$ (average $=2.0 \mu \mathrm{m}$ ), width $0.4-0.6 \mu \mathrm{m}$ $($ average $=0.5 \mu \mathrm{m}), \quad$ depth $\quad 0.4-0.6 \mu \mathrm{m} \quad($ average $=0.5 \mu \mathrm{m})$ (detailed dimensions are presented in Appendix B Categories 2(a)-(c)).

TEM. Not possible as too rare and small.

Chemistry. (See Appendix C.) Elements confined to the microbioids are diverse and include $\mathrm{F}, \mathrm{Cu}, \mathrm{Ba}$, Th and, with one exception, $\mathrm{K}$. Si is found in only one example. Unique to this category of microbioids is Th (thorium), which occurs in significant amounts. The maximum amount of $\mathrm{Th}$ measured in any analysis was $38 \mathrm{wt} . \%$ (LL(BP)2/1).

Interpretation. There are several possible explanations for the presence of $\mathrm{Th}$, but none are definitive. Thorium usually occurs in sediments as the phosphate, monazite or in zircon. Absence of $\mathrm{P}$ and $\mathrm{Zr}$ indicates that these forms are absent. Most Th minerals contain $U$ and rare-earth elements, but these again are not detected. Therefore, the mineral is likely to be artefactural and possibly/probably a thorium oxide (in the form of the hydroxide $\left.\mathrm{Th}(\mathrm{OH})_{4}\right)$ produced by the chemical breakdown, probably of monazite which is a common clastic mineral. The 3D shape simulates that of naviculate diatoms, indeed, these (but much larger in size $\sim 40 \mu \mathrm{m} \times 8 \mu \mathrm{m})$ were seen on fractured surfaces of the rock matrix in the FE-SEM, but there is no surface ornamentation, no raphe nor traces of two valves. A lack of ornament could perhaps be explained by the partial

(d) 5/2, rod with rounded and truncated ends on same surface as $\mathrm{CaF}_{2}$ spheres; (e) HD450/2; (f) HD6/1, short rod covered with granules; (g), (h) LL11D, Laevolancis spores, note groove below rod in (h); (i) LL(BP)2, example with granular surface; (j) LL(BP)5/4, acicular form; (k) LL38/3, rod penetrating fossil surface, note adhering silica spheres. (1)-(n) Category 2b, short rods, all SEMs: (1) LL(BP)6/2, surface of arthropod cuticle, scale bar $=1 \mu \mathrm{m}$; (m) HD(UF)216A/10 (NMW96.30G.5), scale bar =1 $\mu \mathrm{m}$; (n) HD(UF)216A/3, Lower Devonian coprolite containing spores with rods, scale bar $=10 \mu \mathrm{m}$. (o)-(u) Category 2c, all LL(BP)2/1 except (t) LL(BP)GT1, all SEMs: (o) intact mass of the dyad Laevolancis sp, scale bar $=200 \mu \mathrm{m}$; (p) cluster of spores with smooth distal surfaces, microbioids are bottom right, scale $\operatorname{bar}=10 \mu \mathrm{m}$; (q) the two orientations of the microbioid, scale bar $=1 \mu \mathrm{m}$; (r) 3D view of microbioid with superficial discs, scale bar $=0.5 \mu \mathrm{m}$; (s)-(u) scale bars $=0.5 \mu \mathrm{m}$. 

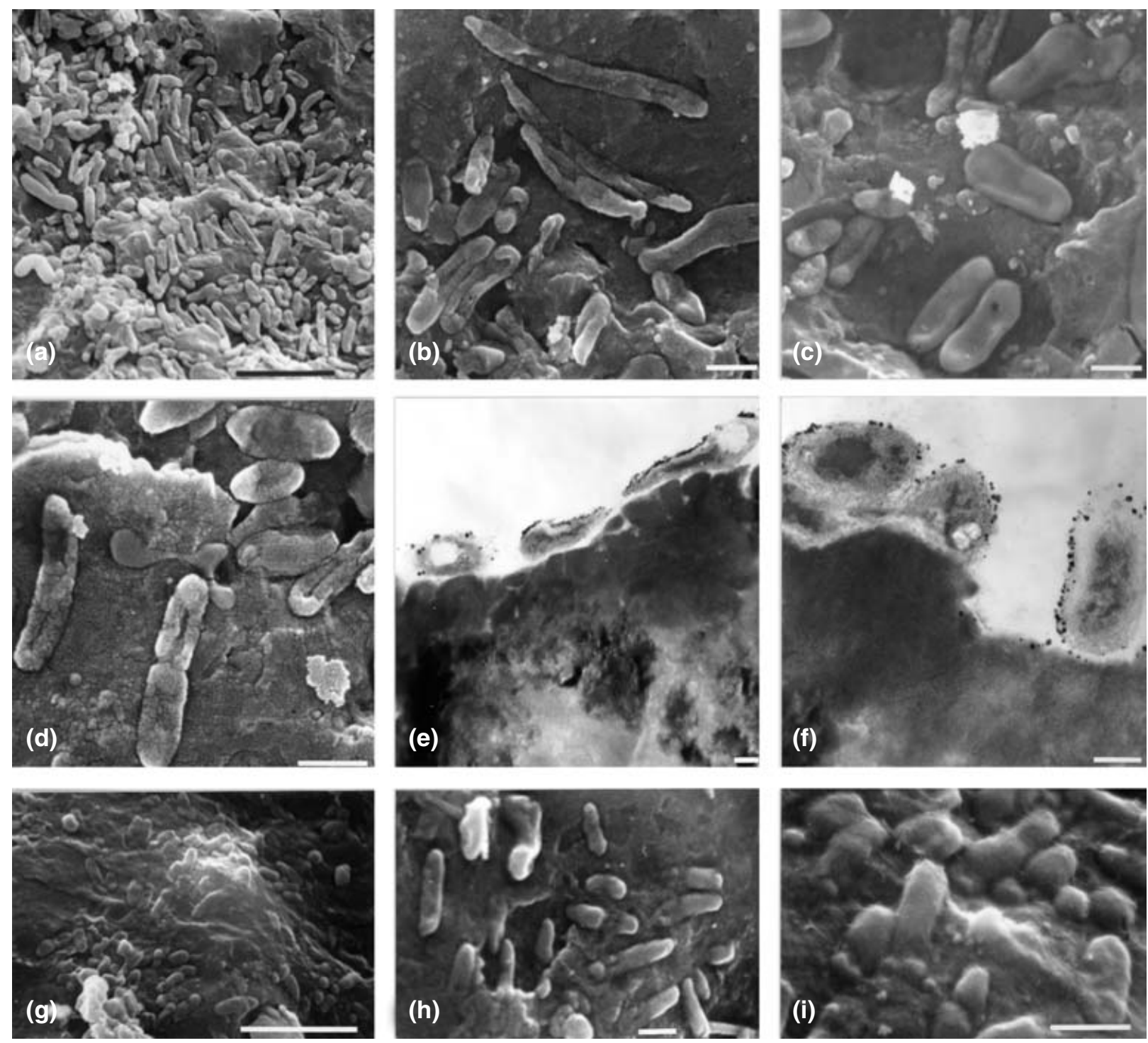

Fig. 5. Category 2d, 'rods' of varying length, with initial W signature on Lochkovian mesofossils from North Brown Clee Hill (HD), all $\mathrm{HD}(\mathrm{KH}) 9 / 14$ except (g) HD(KH)9/14A. (a)-(d) and (g)-(i) SEMs, scale bars $=1 \mathrm{~m}$, except (a) and (g) $=5 \mu \mathrm{m}$. (e), (f) TEMs, microbioids in TS and oblique LS, note homogeneous dark areas or voids at centre, surrounded by a lighter sometimes granular layer, scale bars $=0.1 \mu \mathrm{m}$.

dissolution of a siliceous wall, indeed uneven topography in one example might seem to indicate this (Fig. 4(s)), but diatoms treated with $\mathrm{HF}$ show enhanced relief of the ornamentation (Pike 2004). A further possibility would be complete dissolution of the walls during extraction leaving cell contents that had already been permineralized. Partial degradation, before mineralization could also account for the small size, which is at the very lowest limits for diatoms. Thus permineralized diatoms cannot be entirely eliminated. However, since the surface ornamentation extends to the inner surface of the valves, an internal mould should reflect this.

Category 2d. Variable length: weak tungsten (W) signature (Figs 5(a)-(i))

Preparation. Prepared by Dr Kate Habgood in Cardiff. HF maceration possibly incorporating heavy mineral separation procedures. Both specimens from the same batch (see Appendix A).

Substrates. Lochkovian (from North Brown Clee Hill): \pm circular intact bivalved sporangium of Resilitheca salopense (HD $(\mathrm{KH}) 9 / 14$, lacking subtending axis, with microbioids on sporangium wall originally viewed by SEM. Absent on 'lower' surface. Bifurcating axis with slight swellings with irregular outline at distal ends: microbioids in patches over surface $(\mathrm{HD}(\mathrm{KH}) 9 / 14 \mathrm{~A})$.

Microbioids. The microbioids are most abundant on Resilitheca and show greatest variability in length and shape (Figs 5(a)-(d)). They are consistently longer than wide, some considerably so. Surfaces are usually smooth, but may be collapsed, and sometimes traversed by deep grooves (Figs 5(b) and (c)). Length 1.0-4.1 $\mu \mathrm{m}$ (average $=2.1 \mu \mathrm{m}$ ), 
width $0.4-1.0 \mu \mathrm{m}$ (average $=0.6 \mu \mathrm{m})$. Those on the bifurcating axis (Figs 5(g)-(i)) are somewhat shorter and less distinct in some areas. Length $1.0-2.1 \mu \mathrm{m}$ (average $=1.6 \mu \mathrm{m})$, width $0.5-0.6 \mu \mathrm{m} \quad$ (average $=0.5 \mu \mathrm{m}) \quad$ (detailed dimensions are presented in Appendix B Categories 2(d), 3(a), 4(i)-(iii), bacteria (ii) and (iii)).

TEM. ( $\mathrm{HD}(\mathrm{KH}) 9 / 14)$. Figure 5(e) and (f) show variety in shapes, but each microbioid has a dark core surrounded by a lighter more diffuse zone. Voids may occur in both central and outer regions.

Chemistry. (See Appendix C.) Analyses showed a wide range of elements, all except $\mathrm{C}$ and $\mathrm{O}$ in trace amounts. Particularly notable are $\mathrm{Br}$ and $\mathrm{W}$ in $\mathrm{HD}(\mathrm{KH}) 9 / 14 \mathrm{~A}$ and large amounts of $\mathrm{W}$ in $\mathrm{HD}(\mathrm{KH}) 9 / 14$. $\mathrm{HD}(\mathrm{KH}) 9 / 14 \mathrm{~A}$ showed $\mathrm{S}$. The maximum amount of $\mathrm{W}$ recorded in any analysis was $4.97 \mathrm{wt} \%$ $(\mathrm{HD}(\mathrm{KH}) 9 / 14)$.

Interpretation. As these two specimens had undergone separation using sodium polytungstate, it was assumed that part of the signals resulted from incomplete washing. They were therefore washed and re-analysed. Similar results were obtained for $\mathrm{HD}(\mathrm{KH}) 9 / 14 \mathrm{~A}$, but $\mathrm{HD}(\mathrm{KH}) 9 / 14$ no longer showed $\mathrm{Na}, \mathrm{Cl}, \mathrm{K}$ or $\mathrm{W}$. Such variation may reflect ineffective washing, possibly due to the gold coating, or differences in composition over the specimen (exactly the same area could not be re-examined in $\operatorname{HD}(\mathrm{KH}) 9 / 14)$. It seems likely that these are bacteria, but probably recent bacteria and had 'accumulated' mineral elements during extraction procedures, although $\mathrm{W}$ and sometimes $\mathrm{Br}$ is also recorded in similar-looking recent bacteria grown on mesofossils and a glass petri dish surface during the course of experiment 1a (see observations on extant bacteria, p. 21 et seq. (ii) Rods). The mesofossils used in experiment 1a had been extracted without the use of sodium polytungstate. The grooves illustrated in Figs 5(a)-(d) may result from collapse of living bacteria on drying.

\section{CATEGORY 3 - Filaments/tubes}

Category 3a. Chains of cylindrical units (Figs 6(a)-(g))

Procedures. Standard HF extraction techniques in Manchester, $\mathrm{HCl}$ stored (one pooled batch of Př́ídolí specimens from Ludford Lane, see Appendix A).

Substrate. Single valve of Hollandophyton colliculum (LL(BP)2, Figs 6(a), (b), (d) and (e)), with intact outer wall and part of a dehiscence area plus subtending axis; apex of sporangium with walls and bevelled margin intact, some in situ spores (LL(BP)2/4, Figs 6(c), (f), (g)).

Microbioids. The example on Hollandophyton is $190 \mu \mathrm{m}$ long and traverses the flat surface of the depressed interconnecting band between valves (Figs 6(a) and (b)) where the surface is partially covered by minute granules. Two other examples occur on the other sporangium and are smaller and adhere less intimately to the sporangium surface that is covered by small spheres (Figs 6(f) and (g)). In all specimens, the surfaces of the individual units of the microbioid are irregularly undulating (Figs 6(e) and (g)). Detailed dimensions are presented in Appendix B Categories 2(d), 3(a), 4(i)-(iii), bacteria (ii) and (iii). In the Hollandophyton example, the units are compressed with a rectangular outline with a more or less uniform width and more variable length (Fig. 6(d)). Length $3.5-4.3 \mu \mathrm{m} \quad($ average $=3.8 \mu \mathrm{m})$, width $2.5-2.7 \mu \mathrm{m}$ (average $=2.6 \mu \mathrm{m}$ ). The whole chain appears draped by a thin continuous film with the surface of the sporangium, which sometimes has a distinct edge (arrows in Fig. 6(e)). Adjacent units are united by narrow strands $(<0.8 \mu \mathrm{m}$ wide) and of varying distances apart. The better-preserved example on the second sporangium comprises a crescent of less compressed units separated by diverse constrictions (Figs 6(f) and (g)). Again, units are of more or less of uniform width, but vary in length. Length $3.3-4.4 \mu \mathrm{m}$ (average $=3.9 \mu \mathrm{m})$, width $1.9-2.1 \mu \mathrm{m}$ (average $=2.0 \mu \mathrm{m})$. The second example (not illustrated), $120 \mu \mathrm{m}$ long, shows less segmentation, except in one area, and is covered by a thin film.

TEM. None.

Chemistry. (See Appendix C.) The spectra of the two bestpreserved examples are more or less the same as those of the backgrounds within analytical uncertainty. They differ in that $\mathrm{LL}(\mathrm{BP}) 2 / 4$ spectra contain traces of $\mathrm{Si}$ and $\mathrm{S}$ in addition to $\mathrm{C}, \mathrm{O}, \mathrm{Cl}$ and $\mathrm{Ca}$.

Inferences. From general morphology, these microbioids resemble filamentous cyanobacteria (see also observations on extant bacteria (iii) Cyanobacteria, p. 22.) and they are tentatively identified as such. The very close association of at least one of the specimens with the substrate and similarities in general chemical composition might indicate their antiquity. However, our observations on cultures of living nostocalian cyanobacteria, particularly on the surface textures of the cells of Pseudoanabaena catenata (Fig. 9(1)), together with their presence in two specimens prepared at the same time strongly suggest that they are recent contaminants. Our reservations on unequivocal assignation to the cyanobacteria relate to the small diameters of the cells which are at the lower limit for that group, and fall into the range of Prochlorophyta or filamentous bacteria. However, some shrinkage may have occurred during air-drying.

Category $3 b$. Unsegmented elongate structures (Figs 6(h)-(m))

Preparation. Standard HF extraction techniques on Př́dolí specimens from Ludford Lane prepared in Manchester (one individual batch plus one pooled batch, $\mathrm{HCl}$ stored) and Cardiff (one batch) (see Appendix A).

Substrates. All Prrídolí: include incomplete sporangium of Hollandophyton (LL(BP)2, Fig. 6(m)) three spore masses (LL(A)2/3 (Figs 6(j) and (k)), LL6/6 and LL12E (Fig. 6(1)) and nematophyte tubes (LL12C, Figs 6(h) and (i)). 

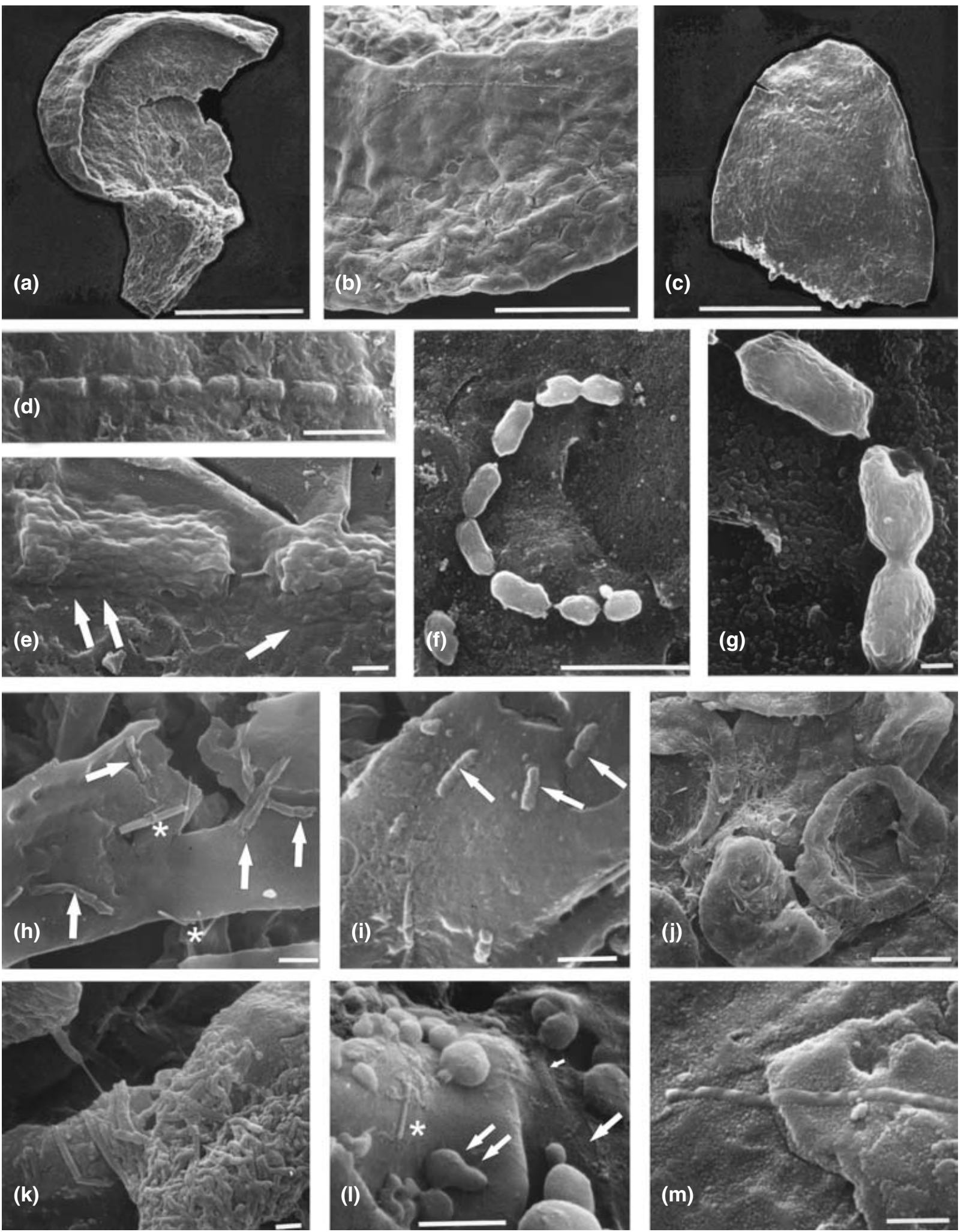

Fig. 6. Filaments/tubes on Př́dolí mesofossils from Ludford Lane (LL), all SEMs. (a)-(g) Category 3a, chains of cylindrical units. (a), (b), (d), (e) Př́idolí Hollandophyton colliculum LL(BP)2: (a) entire specimen with subtending axis and partial valve (viewed from inside) and border, scale bar $=500 \mu \mathrm{m}$; (b) part of (a) magnified, note filament on smooth band connecting valves, scale bar $=100 \mu \mathrm{m}$; (d) chain of separated cells, scale bar $=10 \mu \mathrm{m}$; (e) two adjacent cells partially connected by strand, arrows indicate limit of a smooth margin, scale bar $=1 \mu \mathrm{m}$. (c), (f), (g) Přídolí unidentified sporangium LL(BP)2/4; (c) proximal part of sporangium, scale bar $=500 \mu \mathrm{m}$; (f) chain of cells from (c), scale bar $=10 \mu \mathrm{m}$; (g) chain of cells magnified from (f), scale bar $=1 \mu \mathrm{m}$. (h) $-(\mathrm{m})$ Category $3 \mathrm{~b}$, unsegmented elongate structures. (h), (i) LL12C scale bars $=1 \mu \mathrm{m}$, fragments of tubes of a nematophytalian complex showing flattened, often curved ribbon-like (h) and 
Microbioids. Abundant and aggregated strap-shaped unbranched structures $(0.2-0.5 \mu \mathrm{m}$ wide; average $=0.3 \mu \mathrm{m}$, $n=10$ and at least $5 \mu \mathrm{m}$ long) appear draped over individual hilate smooth spores (Fig. 6(k)) and continue over adjacent examples (Fig. 6(j)). The small number of terminations visible are rounded. Smaller and rarer examples circa $0.2 \mu \mathrm{m}$ wide (small arrow in Fig. 6(1)), are associated with smooth indeterminate spores and a titanium-rich rod (* in Fig. 6(1)), and intermingle with possible tapetal residues (double arrow in Fig. 6(1)). Also present are similarly sized and shaped grooves that resemble dissolution tracks (single arrow in Fig. 6(1)). The single example on the surface of the Hollandophyton sporangium (Fig. $6(\mathrm{~m})$ ) is smooth, unbranched, $0.2 \mu \mathrm{m}$ wide and greater than $12 \mu \mathrm{m}$ long, and has a rounded intact tip. It passes below the filament interpreted as a cyanobacterium (Fig. 6(b)) but above the rounded particles on the sporangium surface. Specimens associated with nematophyte tubes are far more fragmentary and of more variable diameter (circa $0.3 \mu \mathrm{m}$ ) (arrows in Fig. 6(h)). Also present are more elongate rod-shaped structures (arrows in Fig. 6(i)).

\section{TEM. Too small and rare.}

Chemistry. (See Appendix C.) In all examples, the spectra are virtually identical to the substrates and at least demonstrate the absence of any microbioid permineralization. The exceptions have straight, parallel sides and are rich in titanium (* in Figs 6(h) and (1)).

Interpretation. Neither cells nor branching have been recorded in the strap-shaped structures. The overall dimensions fall into the lower part of the size range of filamentous bacteria including actinomycetes. The latter have been recorded, if rarely, in the fossil record (e.g. Wilkinson 2003). The age of the structures remains debatable; the isolated example passes below the presumed filamentous cyanobacterium, but above a sheet of featureless material closely associated and apparently continuous with the latter. The aggregations of probably unbranched hyphae associated with the spores in Figs 6(j) and (k) may be ancient. Another possible pointer to antiquity relates to the elongated grooves that are less well defined than those recorded under the rutile rods on the spore wall and might indicate dissolution pits resulting from enzymic activity (Fig. 6(1)).

\section{CATEGORY 4 - Associations of microbioids and non-cellular material}

These comprise rods, spheres, filaments, disorganized sheets and strands (Figs 7 and 8).
Preparation. Prepared by Dr Una Fanning in Cardiff over 20 years ago. The exact techniques used are unknown but all specimens were from the same batch (see Appendix A).

Substrates. Lochkovian mesofossils from North Brown Clee Hill.

(i) $\mathrm{HD}(\mathrm{UF}) 216 \mathrm{~B} / 3$ (Fig. 7) Resilitheca sporangium with almost complete reniform outline (Fig. 7(a)): comprising two valves and typical retusoid spores. The associations concentrated on the outer surface were originally interpreted as a resilient 'cuticular' spore sac (Edwards et al. 1995), with occasional spheres and filaments on spore surface (Fig. 7(b)).

(ii) $\mathrm{HD}$ (UF)216A/6. Spore mass with permanent unfused dyads (Fig. 8A) (Wellman et al., 1998b).

(iii) $\mathrm{HD}(\mathrm{UF}) 216 \mathrm{~B} / 4$. Fragment of sporangium with remnants of narrow border and smooth trilete spores (Fig. 8(b)-(d)).

(iv) $\mathrm{HD}(\mathrm{UF}) 216 \mathrm{~B} / 1$. Fragment of sporangium with spores sandwiched between two walls (Fig. 8 (f) and (g)).

(v) $\mathrm{HD}(\mathrm{UF}) 216 \mathrm{~B} / 2$. As for (iv) but with traces of a narrow border (Fig. 8 (e), (h) and (i)).

Microbioids. All examples show predominantly rods, with a variation in proportions of microbioids and their association with non-cellular material. They will therefore be initially described separately.

\section{(i) $\mathrm{HD}(\mathrm{UF}) 216 \mathrm{~B} / 3$}

$S E M$. Rods on the sporangial wall are of more or less uniform width $(0.4-0.7 \mu \mathrm{m})$, but with variable length $(1.2-3.0 \mu \mathrm{m})$ and sometimes aligned end-to-end (arrow in Fig. 7(c)) (detailed dimensions are presented in Appendix B Categories 2(d), 3(a), 4(i)-(iii), bacteria (ii) and (iii)). The spheres are more diverse, with diameters of $0.3-1.0 \mu \mathrm{m}$ and ranging from 'perfect' examples to smaller spheres with irregular surfaces that may form a layer of some thickness (Figs 7(c)-(e)). Numerous spheres also occur on and between spores and on the inner surface of the sporangium wall. Figure 7(b) shows an area of a proximal surface close to the gaping trilete, bearing rods, short filaments and small spheres. Non-cellular material ranges from small sheets with irregular margins (Fig. 7(c)) to isolated or fretworks of strands (Figs 7(f) and (g)).

TEM. Areas outside the spore mass present a highly disorganized appearance, but with prominent circular and more elongate dark structures interpreted as sections mainly

\footnotetext{
shorter rod-like structures (arrowed (i)), Straight-sided rods on (h) $(*)$ are Ti minerals; (j), (k) part of mass of hilate spores with abundant interwoven non-septate structures $\operatorname{LL}(\mathrm{A}) 2 / 3$, scale bars $=10 \mu \mathrm{m}$ and $1 \mu \mathrm{m}$, respectively; (1) part of smooth surface of spore with spheres (Category $1 \mathrm{~g}$ ) (double arrow = outgrowth), narrow tubes (small arrow) and a groove (single arrow). Straight-sided rod is Ti mineral $(*)$, spherical structures of unknown affinity, possibly tapetal. LL12E, scale bar $=1 \mu \mathrm{m}$; (m) part of surface magnified from Fig. 6(b) with unsegmented narrow tube. Scale bar $=1 \mu \mathrm{m}$.
} 

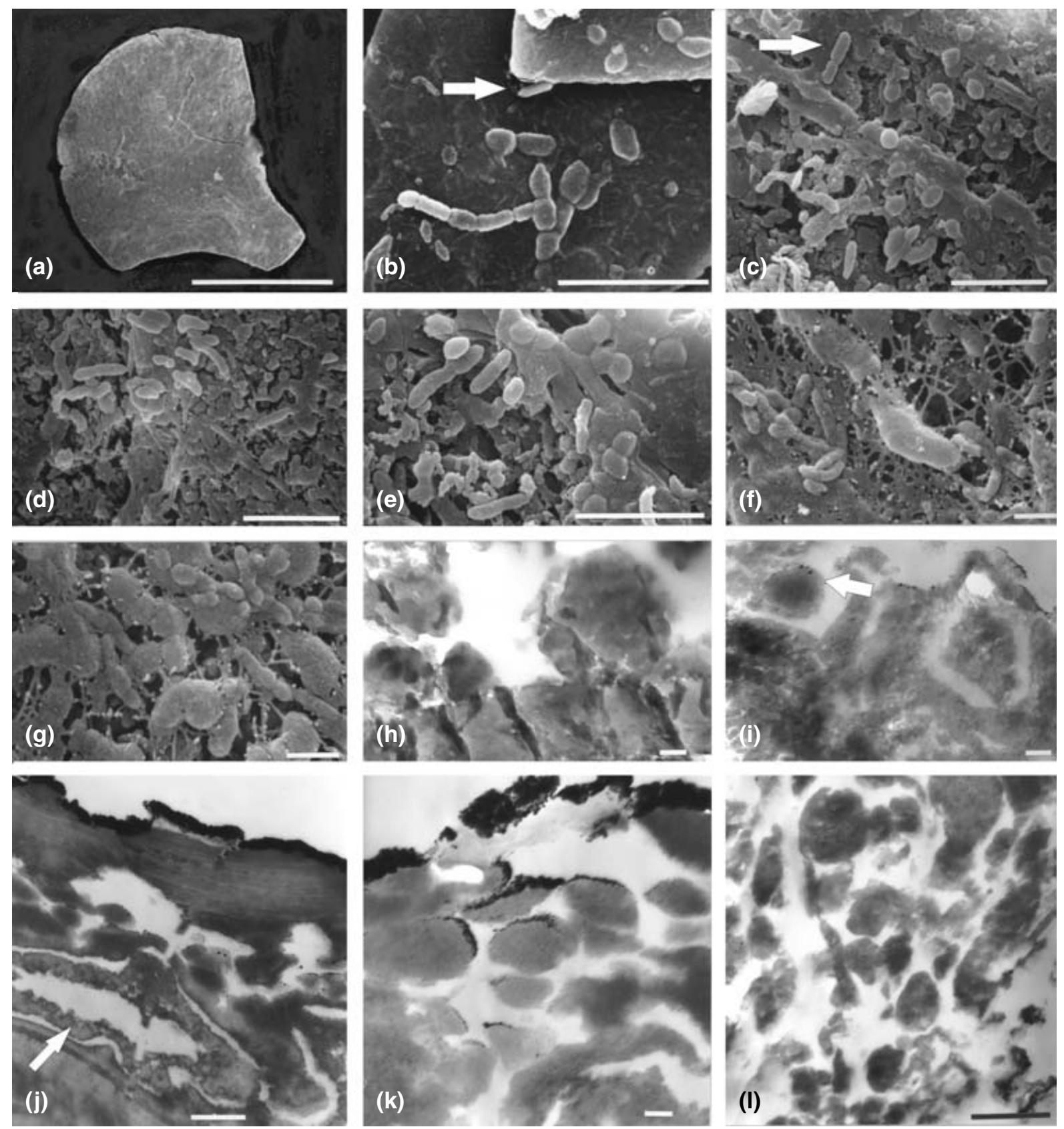

Fig. 7. Category 4(i), associations of microbioids and non-cellular material on a Lochkovian mesofossil (Resilitheca salopensis) from North Brown Clee Hill. HD(UF)216B/3. (a)-(g) SEMs. (a) Surface of cuticle on inside of sporangial valve, scale bar $=500 \mu \mathrm{m}$. (b) Filaments and rod-shaped structures on surface of spore (arrow indicates Ti rod), scale bar $=5 \mu \mathrm{m}$. (c)-(g) Areas of outer surface of cuticle demonstrating variation in appearance of microbioid associations: (c)-(e) scale bars $=5 \mu \mathrm{m}$; (f), (g) scale bars $=1 \mu \mathrm{m}$. (h) -(l) TEMs. (h) Section through tapetal residue on spore comprising numerous spheres, cf. with Fig. 7(j) where spore wall (arrowed) is composed of similar structures, scale bar $=0.1 \mu \mathrm{m}$. (i)-(1) Sections through rods and spheres: (i) arrowed microbioid has central darker area, scale bar $=0.1 \mu \mathrm{m}$; (j) cuticularized wall of sporangium with white lamellae, covering sections through microbioids ( \pm homogeneous) and spores (arrow), scale bar $=0.5 \mu \mathrm{m}$; (k) microbioids with \pm homogeneous construction but some areas less electron-dense than others, scale bar $=0.1 \mu \mathrm{m}$; (l) covering with more granular appearance of microbioids. Scale bar $=0.5 \mu \mathrm{m}$.

through rods. Some have a darker core (Fig. 7(i)). The surrounding matrix is more granular occasionally surrounding circular voids or less densely aggregated areas (Fig. 7(1)). A layer, $0.7 \mu \mathrm{m}$ thick with white lamellae, is interpreted as that enclosing the spores and confirms its cuticular nature (Fig. 7(j)). It is notable that microbioids (homogeneous and often bilayered) occur under this layer and surrounding the spores where they intermingle with spherical aggregates of numerous much smaller spheres. The latter structures also occur on the surfaces and between spores. Thus the structures sectioned in Fig. 7(h), which are made up of the very small spheres, occur on spore surfaces, while the spheres 

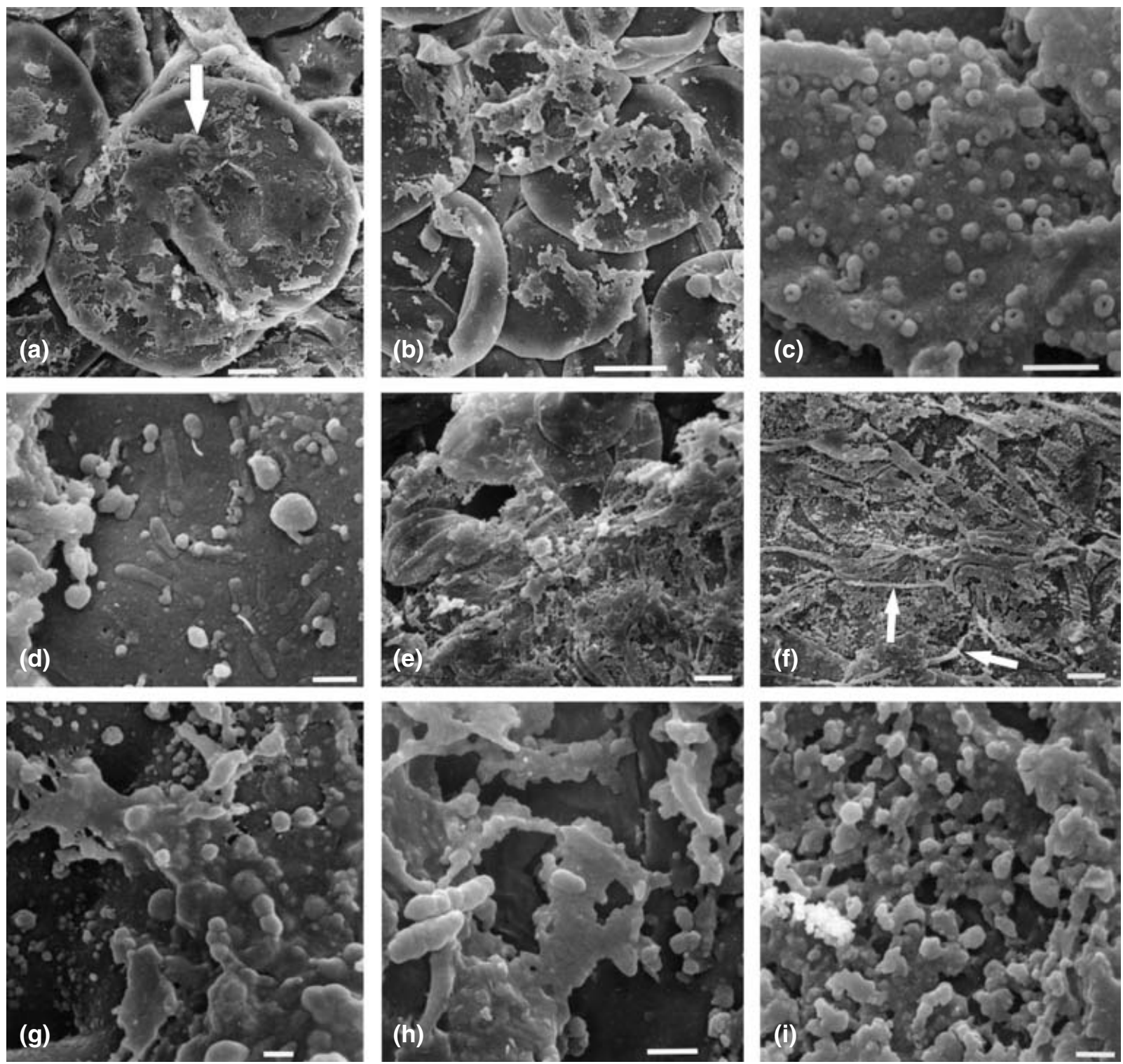

Fig. 8. Category 4(ii)-(v), associations of microbioids and non-cellular material on Lochkovian mesofossils from North Brown Clee Hill, all SEMs. (a) Category 4(ii), Dyad with incomplete sheets and rods (arrow), HD(UF)216A/6 (NMW97.42G.2), scale bar $=10 \mu \mathrm{m}$. (b)-(d) Category 4(iii), Ambitisporites sp. with sheets and rods, $\operatorname{HD}(\mathrm{UF}) 216 \mathrm{~B} / 4$ : (b) scale bar $=1 \mu \mathrm{m}$; (c) spheres with central depressions, scale bar $=1 \mu \mathrm{m}$; (d) rods and spheres, scale bar $=1 \mu \mathrm{m}$. (e), (h), (i) Category 4(v), Mass of spores with remains of sporangium wall, $\mathrm{HD}(\mathrm{UF}) 216 \mathrm{~B} / 2$ : (e) scale bar $=10 \mu \mathrm{m}$; (h) short filaments, spheres and irregular sheets, scale bar $=1 \mu \mathrm{m}$; (i) spheroids of granular remains of cell wall, scale bar $=1 \mu \mathrm{m}$. (f), (g) Category 4(iv), $\mathrm{HD}(\mathrm{UF}) 216 \mathrm{~B} / 1$ : (f) disintegrating sporangium wall with traces of cell walls (arrow), scale bar $=10 \mu \mathrm{m} ;(\mathrm{g})$ spheres and short filaments covered by a film, scale bar $=1 \mu \mathrm{m}$.

themselves comprise the wall of the intact spore (arrowed in Fig. $7(\mathrm{j}))$.

Chemistry. (See Appendix C.) All spectra of filaments, small spheres and spores show $\mathrm{C}, \mathrm{O}$ and traces of $\mathrm{Ca}$ except for one rod with an additional $\mathrm{Cl}$ and $\mathrm{Ti}$ signature.

Interpretation. This specimen is of some importance in that it shows ultrastructural diversity in the microbioids. The composite spheres are similar to the extrasporal particles described in the original description of Resilitheca (Edwards et al. 1995) and comparable to developmental structures such as Ubisch bodies and perispore. The non-mineralized homogeneous structures (rods, with the one exception of the mineral rutile (arrow in Fig. 7(b)) and spheres) embedded in disorganized material resemble bacteria in the extrapolysaccharide matrix of a biofilm. The sheets and strands ('fibres') in the latter show similarities with many of the samples dehydrated using a variety of techniques by Fratesi et al. (2004); for example, their Figs 1(c), 5(a), 6(a) and 8(f)). 


\section{(ii) $\mathrm{HD}(\mathrm{UF}) 216 \mathrm{~A} / 6$ (NMW97.42G.2)}

$S E M$. The smooth surfaces of the spore pairs (dyads) are partially covered by flat, sometimes minutely perforated, sheets with irregular outlines and occasional strands with which rod-shaped structures are associated (Fig. 8(a)) (length 2.2-2.8 $\mu \mathrm{m}$, width $0.6-1.1 \mu \mathrm{m})$. Detailed dimensions are presented in Appendix B Categories 2(d), 3(a), 4(i)-(iii), bacteria (ii) and (iii). The sheets sometimes extend between adjacent spores.

TEM. A homogeneous layer overlies a number of large irregularly shaped voids to the outside of the spore mass. Sections did not pass through any bacteria.

Chemistry. (See Appendix C.) No analyses available because spore mass was sacrificed previously for TEM.

Interpretation. Sheet-like structures are probably remnants of the cuticle to the outside of the sporangium wall (Wellman et al. 1998b). Any bacteria are probably recent contaminants rather than those involved in the decay process.

\section{(iii) $\mathrm{HD}(\mathrm{UF}) 216 \mathrm{~B} / 4$}

SEM. Very fragmentary sheets sometimes with minutely granular surfaces extend over and between spores (Fig. 8(b)), the surfaces of which show partially embedded rods and spheres of irregular size (Fig. 8(d)). An unusual feature is the pit/depression in the centre of the largest granules (Fig. 8(c)). The rods are of variable length $(0.9-1.5 \mu \mathrm{m})$, but more constant width $(0.3-0.4 \mu \mathrm{m})$. Detailed dimensions are presented in Appendix B Categories 2(d), 3(a), 4(i)-(iii), bacteria (ii) and (iii).

\section{TEM. None.}

Chemistry. (See Appendix C.) The spectra show that the rods are composed of only $\mathrm{C}$ and $\mathrm{O}$ but the less well organized material, irregular spheres and sheets also contain $\mathrm{Ca}$ and, together with the spore, $\mathrm{Cu}$.

Interpretation. The tattered sheets may represent the remains of the sporangial wall or tapetal residues or alternatively a disintegrating biofilm (cf. Fratesi et al. 2004). The microbioids appear more closely associated with spore surfaces and have a similar chemistry (rods). The timing of such colonization remains inconclusive, but is probably recent because the microbioids are not permineralized.

\section{(iv) $\mathrm{HD}(\mathrm{UF}) 216 \mathrm{~B} / 1$ and (v) $\mathrm{HD}(\mathrm{UF}) 216 \mathrm{~B} / 2$}

SEM. The superficial encrustrations are similar in that small areas of smooth sheets intermingle with short filaments and clusters or single small spheres $(0.2-0.5 \mu \mathrm{m}$ diameter) with irregular surfaces (Figs $8(\mathrm{~g})$ and (i)). Spheres are also aggregated into short chains (Fig. 8(h)). In both specimens, smooth strands possibly mark the outlines of cells (Fig. 8(f)). There are no well-defined rods.
TEM. None.

Chemistry. (See Appendix C.) The spectra show similar composition of the spores although with $\mathrm{Cl}$ in $\mathrm{HD}(\mathrm{UF}) 216 \mathrm{~B} /$ 2, where the covering also contains $\mathrm{Cu}$.

Interpretation. The reticulum of strands covering the spores probably represents the remains of cells of the sporangium wall, also represented by the irregular sheets and granular material. Whether or not the more organized/discrete structures, for example the chains in Fig. 8(h), are the remains of bacteria involved in degradation or later contaminants remains conjectural, especially in those where the individual 'cells' of the chain are of different size/shape. The possibility of a dried biofilm is suggested by similarities of these images and those produced on dehydration of biofilms by Fratesi et al. (2004, Fig. 6(A)).

\section{Observations on extant bacteria}

(i) Coccoid forms (Figs 9(g)-(i))

Preparation. See Extant bacteria (2a) in Material and methods section, p. 4. Two types of bacteria, narrow rods (10-20\%) and cocci were present in the isolate (Fig. 9(g)) prepared from soil from a molehill. The latter are analysed here by FE-SEM and EDX. It proved impossible to impose HF extraction procedures on the cultures, as the bacteria would pass through our normal filters.

Substrate. Cocci colonized irregular strands of cellulose (from cellulose powder).

Cocci morphology. Uniformly spherical with few indications of cell division. The average diameter was $1.2 \mu \mathrm{m}$, the minimum $1.0 \mu \mathrm{m}$ and the maximum $1.6 \mu \mathrm{m}$ (detailed dimensions are presented in Appendix B Categories 1(a)-(g), bacteria (i)). Spheres merge into the substrate as if attached by a narrow film. The samples dried out for four months experienced greater collapse with irregularly furrowed surfaces (Figs 9(h) and (i)) and may be in short chains.

\section{TEM. None.}

Chemistry. (See Appendix C.) The spectra of the bacteria are dominated by aluminium from the stub. (In most of our other analyses, a coalified fossil normally lies between the specimen and the stub). Apart from $\mathrm{C}$ and $\mathrm{O}$ the absence of many elements, apart from $\mathrm{K}$ and $\mathrm{Si}$, undoubtedly present in the living cells, probably relates to their presence in quantities below detection limits.

Comparisons. These specimens show far more indications of collapse than in the vast majority of spherical microbioids on the fossils. Exceptions are illustrated on a postulated biofilm covering a fossil spore (cf. Figs 8(c) and 9(h)). Comparable 

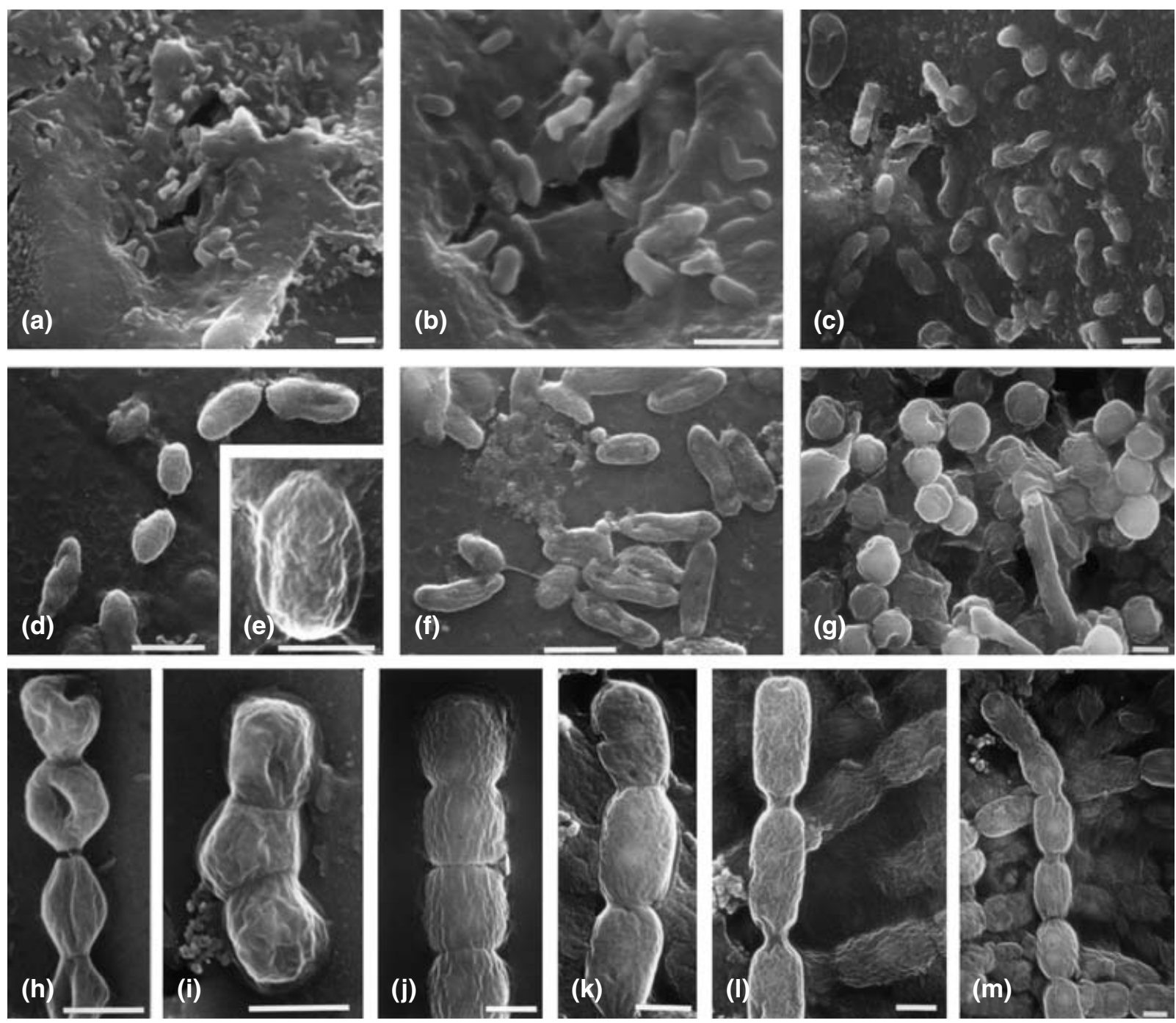

Fig. 9. Extant bacteria ((a)-(i)) and cyanobacteria ((j)-(m)). (a)-(c) Lochkovian mesofossils from North Brown Clee Hill from experiment 1a, air-dried after six weeks in tap water, surfaces are colonized by extant rod-shaped bacteria, scale bars $=1 \mu \mathrm{m}$ : (a), (b) HD447/2; (c) HD447/1. (d), (f) Rod-shaped bacteria colonizing petri dish used in experiment 1a, air-dried after six weeks in tap water, scale bars $=1 \mu \mathrm{m}$. (e) Extant bacterium colonizing surface of a Př́idolí mesofossil from Ludford Lane from experiment 1b, washed then air-dried after six months in soil bacterial culture, $\mathrm{LL}(\mathrm{BP}) 26 \mathrm{~A}$, scale bar $=0.5 \mu \mathrm{m}$. (g) Extant coccoid bacteria from soil bacterial culture used in experiment $1 \mathrm{~b}$, air-dried then left on stub for four months, BP20, scale bar $=1 \mu \mathrm{m}$. (h), (i) Extant coccoid bacteria from soil bacterial culture used in experiment $1 \mathrm{~b}$, washed and centrifuged then air-dried then left on stub for four months, BP24, scale bar $=1 \mu \mathrm{m} .(\mathrm{j})-(\mathrm{m})$ Filaments of Pseudoanabaena catenata, air-dried then left on stubs for four months, scale bars $=1 \mu \mathrm{m}$ : (j) BP14; (k)-(m) BP11.

aggregations into short chains have been noted in a heterogeneous assortment of microbioids present on a decaying sporangium wall (cf. Fig. 8(h) and 9(i)). Such observations would appear to support the biogenicity of the microbioids in these associations interpreted as biofilms, while the lack of mineralization indicates a recent origin.

(ii) Rods (Figs 9(a)-(d) and (f))

(a) Preparation. See Extant bacteria (1a) in Material and methods section, p. 4 and Appendix A.
Substrate. Lochkovian mesofossils (HD447/1 and HD447/ $2)$; surface of petri dish. The mesofossils were selected randomly from the petri dish at the end of the experiment but bacteria were more apparent on smooth-surfaced cuticles, two of which are illustrated here (Fig. 9(a-c)).

Bacteria. Figure 9(c) (HD447/1) shows a variety of shapes, but mainly rods (length $1.5-2.4 \mu \mathrm{m}$, width $0.7-0.9 \mu \mathrm{m}$ ), with smooth, sometimes collapsed wrinkled, surfaces that were presumably produced by dehydration. The majority have discrete outlines, are linked by strands of material 
or merge with the substrate. One area has more circular to oval disc-like structures with and without granular surfaces. A second specimen (HD447/2) has areas with more uniform rods, but of variable lengths (Figs 9(a) and (b)) (length $0.3-0.6 \mu \mathrm{m}$, width $0.2-0.3 \mu \mathrm{m}$ ), and are much smaller than the first with less evidence of shrinkage or collapse. Those on the petri dish are dominated by rod-shaped forms of variable length (length $0.6-1.3 \mu \mathrm{m}$, width $0.3-0.6 \mu \mathrm{m})$, sometimes curved, occasionally joined by strands and even sheets (Figs 9(d) and (f)). The detailed dimensions are presented in Appendix B Categories 2(d), 3(a), 4(i)-(iii), bacteria (ii) and (iii). The elongated grooves and wrinkles were presumably produced by dehydration. The petri dish was re-examined after a further two weeks and then another seven weeks. The morphology of the bacteria was unchanged. Mesofossils from the same macerate that were kept dry as controls did not have any bacteria growing on them.

Chemistry. (See Appendix C.) A wide range of elements was recorded, some specimens show a remarkable similarity between the fossil substrate and the extant bacteria, with variability between the four analyses. In addition to $\mathrm{C}$ and $\mathrm{O}$, $\mathrm{Cl}, \mathrm{Ca}$ and $\mathrm{Fe}$ are detected and, surprisingly $\mathrm{W}$, but this is not ubiquitous. Tungsten occurs in bacteria growing both on mesofossils and on the surface of the petri dish but rarely in the mesofossils themselves and never in the petri dish analyses.

Comparisons. The rod-shaped bacteria exhibiting surface collapse and grooves (Fig. 9(c) mesofossil; Fig. 9(f) on petri dish) are reminiscent of those on a Lochkovian mesofossil, which also had $\mathrm{W}$ present (Figs 5(a)-(d)). Those illustrated in Figs 9(a) and (b), are smaller and might indicate that smaller rods are less likely to show signs of collapse.

(b) Preparation. A few fragments of mesofossils were inoculated with the soil bacterial culture for six months and then air-dried (see Extant bacteria (1b) in Material and methods section, p. 4 and Appendix A).

Substrate. Unidentified Př́dolí mesofossil from Ludford Lane (LL(BP)26A).

Bacteria. The short rod-shaped bacterium in Fig. 9(e) was one of the very few that colonized the mesofossils and shows a typical irregularly patterned surface and shallow grooves. It has not been analysed chemically. The pieces of the mesofossils that were kept dry as controls for six months did not have any bacteria growing on them.

Comparisons. In its small size and surface morphology it resembles the extant bacteria which colonized the petri dish surface in preparation (ii) a (Fig. 9(d)) . (iii) Cyanobacteria (Figs 9(j)-(m))

Preparation. Cultures of Pseudoanabaena catenata (see Extant bacteria (2b) in Material and methods section, p. 5) were rinsed in water and air-dried on thermanox cover slips. FE-SEM observations on the same specimens were repeated after three weeks.

Cyanobacteria. Figures 9(j)-(m) show individual cells and traces of the sheath. Irregular undulations of the surface became more pronounced over the drying time. Cells are of uniform width $(1.21-1.64 \mu \mathrm{m})$, but vary slightly in length $(1.66-2.99 \mu \mathrm{m})$. The detailed dimensions are presented in Appendix B Categories 2(d), 3(a), 4(i)-(iii), bacteria (ii) and (iii).

\section{TEM. None.}

Chemistry. (See Appendix C.) Wider range of elements present compared with the cocci. $\mathrm{Na}, \mathrm{Mg}$ and $\mathrm{Ca}$ are ubiquitous. Notable is the presence of $\mathrm{P}$ and $\mathrm{S}$ in Pseudoanabaena.

Comparisons. Remarkable similarities are noted between, for example, Figs 9(l) and 6(g) in terms of surface features, general shape and size, confirming that the mesofossil-bearing example is a recent contaminant with indications of dehydration. The microbioid illustrated in Figs 6(a), (b), (d) and (e) has cells of a different shape and may represent a different microbial type. It was possibly originally a filament of cylindrical cells lacking marked constrictions between them, and showing much more pronounced dehydration.

\section{Discussion}

In drawing conclusions as to whether the microbioids that we have described that are attached to Silurian and Lower Devonian fossils are indeed Silurian and Lower Devonian bacteria, we have been greatly influenced by criteria set down during similar interrogations of possible Precambrian prokaryote records (e.g. Schopf \& Walter 1983; Westall \& Folk 2003). Schopf \& Walter, in particular, emphasized that problems of demonstration of indigenousness (not modern contaminants) and syngenicity (present when sediment deposited) are exacerbated by the use of maceration techniques, although more recently even bacteria-like forms in sections have proved controversial (Schopf et al. 2002; Brasier et al. 2002, 2005). In establishing biogenicity, Schopf \& Walter (1983) drew attention to the wide-variety of abiotic substances that mimic microorganisms. This is particularly true for spheroids produced not only by minerals but also by organic carbonaceous entities such as proteinoid or lipid microspheres (Fox et al. 1983). For the establishment of biogenicity, Schopf \& Walter listed the combinations of characteristics, including size, size range, abundance, shape, surface features, chemical composition, biological association and evolutionary and geological context as factors that should be taken into account. These guidelines, although 
developed for analysis of Archaean fossils, are adopted here, with most sceptism directed at spheres known to have a variety of abiotic origins.

\section{Spheres}

Almost all those detailed here fall consistently into the lower part of the size range of those described as typical of bacteria (0.5-2.0 $\mu \mathrm{m}$ : Westall 1999). Some occur in pairs reminiscent of dividing cells, while others form chains. Their surfaces may be smooth to slightly granular. All show $\mathrm{C}$ and $\mathrm{O}$ in their elemental spectra but this is probably more a reflection of the composition of the substrate. However, the vast majority exhibit elements more or less confined to the spheres.

Spheres with an Si signature (Fig. 1) show the greatest size range, some falling into that of nanobacteria (category 1a, Figs 1(a)-(f)). They are interpreted as being silica of nonbiological origin and synthesized during extraction processes. This origin has some relevance to the authenticity of spheres released by delicate maceration of cherts in other investigations (e.g. Westall et al. 2001). Spheres composed of $\mathrm{CaF}_{2}$ present in one or two batches are also considered nonbiogenic, being an occasional by-product of HF maceration. Routine boiling in $\mathrm{HCl}$ (a procedure required for its removal) is not routinely performed when macerating to extract delicate mesofossils. However, before dismissing their presence as an unpredictable by-product of the extraction technique, it should be noted that they are hollow (Figs 2(h)-(1)), with some evidence of traces of carbonaceous material. This leads to a possibility that they are coatings of $\mathrm{CaF}_{2}$ on cocci or even chains of such cells, the latter very closely resembling silicified chains of bona fide cells illustrated by Westall (1994, pl. 1e,f). Our batch may have been contaminated by bacteria following extraction, with $\mathrm{CaF}_{2}$ precipitation perhaps facilitated in some way by charges on the surfaces of the bacteria. Some long chains may result from precipitation on hairs or paper fibres. Confusion of calcium fluoride spheres with bacteria is not new. Recognition that spheroids could be produced during extraction processes occurred almost 40 years ago (Bradley 1968). Bradley (1963) had earlier described isolated, clumped or chains (less than 15 'cells') of spheres, circa $0.2 \mu \mathrm{m}$ diameter, and named Micrococcus and Streptococcus sp. from a Lower Cretaceous black lacustrine limestone. These had been isolated by first dissolving the rock in dilute $\mathrm{HCl}$, and then, to promote disagregation of organic matter, with $\mathrm{HF}$. Failure to repeat these extraction products led Bradley to conclude that $\mathrm{CaF}_{2}$ had been produced because all $\mathrm{Ca}$ ions had not been washed out in the original preparations, and that the dark colouration resulted from occluded organic material. He was able to synthesize similar spherical structures following addition of $\mathrm{HF}$ to dilute $\mathrm{Ca}\left(\mathrm{NO}_{3}\right)_{2}$ only in the presence of organic material. In the absence of the latter, crystals were poorly formed and colourless. Indeed he failed to reproduce the dark-brown colour of the fluorite crystals even when he had added 'humic leachates' to the experimental solutions. It is of some relevance here that the $\mathrm{CaF}_{2}$ on our specimens were also probably dark-coloured, as we would have noticed a crystalline deposit on our specimens in screening processes. However, boiling of selected specimens in $\mathrm{HCl}$ removed the $\mathrm{CaF}_{2}$ but did not reveal any evidence of bacteria when reexamined by FE-SEM.

We therefore conclude that, with one exception, none of the spheres we investigated had a biological origin. The exception comprises the spheres of larger size, with framboidal surface characteristics and spectra dominated by $\mathrm{C}$ and O. These, however, we are convinced, are also not bacteria but are organic tapetal residues (Figs 3(1)-(p)). Their restriction to spore surfaces and sporangial cavities in these and other investigations confirms this conclusion, although the processes involved in spore wall development remain poorly understood.

\section{Rods}

Elongate structures resembling bacteria in size and shape have more diverse morphology and probably origins. Some have a predominantly coalified signature (Figs 4(1) and 5), others are more exotic (Figs 4(a)-(k) and (q)-(u)). Those dominated by $\mathrm{Ti}$ exemplify the latter, and we concluded that they were rutile crystals. In morphology, the majority far more closely mimicked bacilli with their rounded ends (Figs 4(a)-(c)) than, say, the much larger tourmaline crystals with truncated fractured ends that Westall (1999, Fig. 2(e)) illustrated embedded in a silicified biofilm. However, rare examples showing truncation were observed (Figs 4(d) and (e)). On Westall's biogenicity criteria, the rutile microbioids present 'too rigid' an appearance to be bacterial replicates, although a number of bacteria have straight parallel sides. However, what is unusual is their intimate association with the substrate surface, to the extent that some crystals lie in grooves, of similar size and shape, on the surface (Fig. 4(h)), the latter being very similar to the dissolution pits sometimes produced by bacteria (e.g. Edwards et al. 2001b) on mineral surfaces. Alternatively, the depressions may have resulted from the pressing of a comparatively hard crystal onto a 'softer' spore surface on compression during diagenesis. This interpretation implies that the rods were present during lithification - an indication of sygenicity - and rutile crystals are a common detrital mineral in clastic rocks. Similar Ti-rich rods are also visible in the rock matrix when viewed in the FE-SEM. Indeed it is also possible that the rutile rods were merely trapped in surface irregularities on the spore walls. Whatever their origin, these rods are interpreted as detrital minerals rather than a mineral replacing bacterial cells.

The very distinctive naviculate-shaped forms, reminiscent of diatoms, would seem compelling evidence for biogenicity (Figs 4(q)-(u). An absence of silica would be anticipated following the extraction procedure involving HF. Similarlyshaped but considerably larger diatoms were present in one area on a piece of host rock viewed in the FE-SEM. In this scenario, the mineralization of the contents of the diatom by a Fl-based compound with traces of other elements including Thorium (Th) would have occurred in the final phases of extraction by an as yet unexplained process although the much smaller size of the microbioids, compared with known 
diatoms, and the lack of surface pattern, cannot be explained by this. The alternative, that the mineral, with a crystal shape we have not been able to trace in the literature, was abiotically formed, seems the most prudent interpretation until other evidence for biogenicity is found.

The rod-shaped microbioids illustrated in Fig. 5 are considered to represent bacteria, particularly when compared with cultured bacteria (Fig. 9(e)). The mineral signature, here supplementing an organic signature, has an explanation again in incomplete washing, this time following sodium polytungstate treatment. However, in this case, not only do the microbioids have variable and curved shapes (a character used by Westall (1999) to demonstrate biogenicity in rodshaped structures), but they were persistent after washing. It seems likely that the charges on the bacterial walls caused chelation/adhesion of a variety of ions, indeed traces of $\mathrm{W}$ were also recorded in extant rod-shaped bacteria growing on the surface of a petri dish (Figs 9(d) and (f)). As regards indigenousness, the collapsed nature of the bacteria and their morphological similarity to the extant bacteria growing on the surface of a petri dish (Figs 9(d) and (f)) suggests that they were recent contaminants, although no ultrastructure was visible in TEMs (Figs 5(e) and (f)). However, expectations of the latter, even in extant examples, are probably unrealistic due to lack of appropriate fixation leading to dehydration and rapid lysis as the samples had been air-dried. Although work in progress on 'recently dead' cultures shows homogenization of cell content (see also Westall 1999), Toporski et al. (2002) illustrated cellular detail six weeks into an experiment involving experimental silicification.

The short rod-shaped structures recorded in Figs 4(1)-(n) are also so similar to the 'induced' contaminants in our experiments that they are again considered recent bacteria, and presumably colonized the macerals some time after extraction. We cannot unequivocally eliminate an ancient origin because the chemical signatures are similar to those of the fossil substrates, raising the possibility that they were fossilized together. However, is it reasonable to expect bacteria to be preserved in organic/coalified forms? As Westall (1999) has pointed out, organic cell contents in bacteria very quickly undergo autolysis such that only cell walls might be anticipated to possess fossilization potential. In addition, the amounts of $\mathrm{C}$ preserved in this way by isolated individual bacteria would be below the resolution of our microscope and also masked by a far stronger $\mathrm{C}$ signal from the coalified substrate. Indeed, in this study it is the absence of minerals that provides evidence for a C-based composition. A possible explanation relates to the excellent preservation of these substrate fossils as charcoal (Glasspool et al. in press). It is known from previous work, particularly on Lower Devonian mesofossils, that the surface (possibly biofilms) including equivocal fungal components (Edwards \& Axe 2004: Fig. 2(k)), are preserved as a consequence of the smouldering fire that resulted in incomplete combustion. Edwards \& Axe (2004: Fig. 2(j)) also illustrated a charcoalified stem of Vaccinium myrtilus in which a cyanobacterium is embedded on a melted surface film (waxes in cuticle?), some fungal hyphae on a Psilotum shoot (2004: Fig. 2(s)) and possibly bacteria on a moss gametophyte (2004: Fig. 2(r)). However, for the specimens described here, the most parsimonious explanation is for a recent origin of these rod-shaped unequivocal bacteria.

\section{Associations of microbioids and amorphous films and strands}

Questions of biogenicity are more readily answered in relation to such associations that show strong similarities to both fossil and recent biofilms. In the case of the latter, our material more closely resembles dried films with bacteria protruding from glycocalyx (extra-polymeric substances) reduced to drapes and strands (Figs 7 and 8), rather than its smooth surface in living examples (Costerton et al. 1986) (Figs 9(a)-(c)). However, it should be emphasized that bacteria are rarely preserved even in lithified microbial mats (Gerdes \& Krumbein 1987; Westall \& Rincé 1994; Briggs 2003). Thus their syngenicity and indigenousness are more problematic and similar arguments can be rehearsed here as presented for the rods. The biofilms lack any permineralization, and ultrastructurally some of the components (rods?) are homogeneous but with an less intensely staining outer area (Fig. 7(i), arrowed). A similar layering can be seen in tiny silicified? filaments/fibrils forming part of a biofilm described from Upper Oligocene to Middle Miocene diatomaceous sediments (Westall 1994), although their biogenicity was again questioned. However, silicified clusters and filaments, similar in size (less than $1-10 \mu \mathrm{m}$ long and $0.1-0.7 \mu \mathrm{m}$ wide) and form to our $\mathrm{CaF}_{2}$ microbioids (cf. Westall Plate 1, Figs (e) and (f) with our Fig. 2) were considered as possible filamentous bacteria - an interpretation further supported by Westall's comparisons with modern diatomaceous sediments and by experimental silicification of microorganisms (Westall et al. 1995). It seems unlikely in the absence of mineralization that the biofilms are ancient, but more likely colonized the surfaces of the mesofossils during aqueous storage in combination with subsequent drying then producing many of the structures noted by Fratesi et al. (2004) when investigating dehydration of biofilms on a sandstone. However, even mineralization does not equate to ancient origin as bacterial films similar to many soft-bodied organisms can be rapidly mineralized in laboratory experiments (e.g. Martin et al. 2003). Finally all the specimens examined under category 4 came from the same batch. The presence of the cyanobacteria (category 3a) can be explained by a very short exposure to tap water and with the filaments adhering to the Hollandophyton on air drying, a salutary experience emphasising the requirement for 'clean' extraction for detection of ancient microbial cells. However, the variation in appearance of the filaments on the two specimens which we have assumed to relate to degree of dehydration (cf. Figs 6(f), (g), 6(d) and (e)) has implications for deliberations on their conspecifity and, in the case of the example where the filament is so intimately associated with the fossil surface (Figs 6(a), (b), (d) and (e)), raises doubts as to whether the specimen is indeed a modern contaminant. 


\section{Summary}

Our studies have reinforced the warnings of many earlier workers on the dangers of drawing conclusions from merely matching gross morphological structures, often showing somewhat complex organization, to those of microbial cells in attempts to demonstrate the biogenicity of structures resembling bacteria in the rock record. Our particular contribution has been to emphasise the importance of awareness of context, the possibility of contamination with modern microbes during preparation and a thorough understanding of the by-products of extraction procedures including acid etching. The majority of such structures we have investigated are either modern contaminants (e.g. rods, cocci, cyanobacteria, biofilms, etc.), minerals that survived acid treatments (e.g. $\mathrm{TiO}_{2}$ ), by-products of spore development or procedural artefacts (e.g. $\mathrm{Si}, \mathrm{CaF}_{2}$ and $\mathrm{Th}$ minerals). The latter are characterized by their unpredictable and very sporadic occurrence and by the diversity of morphological analogues (from isolated spheres to clusters to chains) features that can be related to variation in often very localized chemical environments. Perhaps we were naïve in assuming that Palaeozoic bacteria could be preserved as coalified fossils. Most studies on exceptionally preserved examples are based on lithified examples (e.g. Martill \& Wilby 1994) in which cell contents comprise homogeneous material or crystals of the permineralizing agent (e.g. Liebig et al. 1996). Our optimism was based on the possibility that in wild-fire induced Lagerstätten, bacterial cells might have been preserved together with their Silurian and Devonian substrates - mesofossils that have inordinate botanical and evolutionary importance in their possession of tissues that escaped bacterial and fungal decay (Glasspool et al. in press). However, our results clearly demonstrate that great caution should be exercised in interpreting the presence of microbial cell-shaped objects in any study of microbes in ancient deposits.

\section{Acknowledgements}

We would like to thank Henrik Sass, for advice and cultures, Kevin Davies for TEM and Peter Fisher for analytical technical support. The project was financed by NERC grant $\mathrm{NER} / \mathrm{B} / \mathrm{S} / 2003 / 00228$ which is gratefully acknowledged.

\section{References}

Bradley, W.H. (1963). Unmineralized fossil bacteria. Science 141, 919-921. Bradley, W.H. (1968). Unmineralized fossil bacteria: a retraction. Science 160, 437.

Brasier, M.D., Green, O.R., Jephcoat, A.P., Kleppe, A.K., van Kranendonk, M.J., Lindsay, J.F., Steele, A. \& Grassineau, N.V. (2002). Questioning the evidence for the Earth's oldest fossils. Nature 416, 76-81.

Brasier, M.D., Green, O.R., Lindsay, J.F., McLoughlin, N., Steele, A. \& Stoakes, C. (2005). Critical testing of Earth's oldest putative fossil assemblage from the $\sim 3.5 \mathrm{Ga}$ Apex chert, Chinaman Creek, Western Australia. Precambrian Research 140, 55-102.

Briggs, D.E.G. (2003). The role of biofilms in the fossilization of nonbiomineralized tissues. In Fossil and Recent Biofilms. A Natural History of Life on Earth, eds Krumbein, W.E., Paterston, D.M. \& Zavarzin, G.A. ch. 18, pp. 281-290. Kluwer Academic Publishers, Dordrecht/Boston/ London.

Costerton, J.W., Nickel, J.C. \& Ladd, T.I. (1986). Suitable methods for the comparative study of free-living and surface-associated bacterial populations. In Bacteria in Nature. Volume 2. Methods \& Special Applications in Bacterial Ecology, eds Poindexter, J.S. \& Leadbetter, E.R., ch 2, pp. 49-84. Plenum Press, New York and London.

Deer, W.A., Howie, R.A. \& Zussman, J. (1966). An Introduction to the Rock-Forming Minerals, pp. 415-417. Longman, London.

Douglas, S. \& Douglas, D.D. (2000). Environmental scanning electron microscopy studies of colloidal sulfur deposition in a natural microbial community from a cold sulfide spring near Ancaster, Ontario, Canada Geomicrobiol. J. 17, 275-289.

Edwards, D. \& Axe, L. (2004). Anatomical evidence in the detection of the earliest wildfires. Palaios 19, 113-128.

Edwards, D. \& Richardson, J.B. (2004). Silurian and Lower Devonian plant assemblages from the Anglo-Welsh Basin: a palaeobotanical and palynological synthesis, eds Williams, B.P.J., Hillier, R.D. \& Marriott, S.B Geol. J. (Special issue on The Lower Old Red Sandstone of the AngloWelsh Basin) 39, 375-402.

Edwards, D., Fanning, U., Davies, K.L., Axe, L. \& Richardson, J.B. (1995). Exceptional preservation in Lower Devonian coalified fossils from the Welsh Borderland: a new genus based on reniform sporangia lacking thickened borders. Bot. J. Linn. Soc. 117, 233-254.

Edwards, D., Axe, L. \& Mendez, E. (2001a). A new genus for isolated bivalved sporangia with thickened margins from the Lower Devonian of the Welsh Borderland. Bot. J. Linn. Soc. 137, 297-310.

Edwards, K.J., Hu, B., Hamers, R.J. \& Banfield, J.F. (2001b). A new look at microbial leaching patterns on sulfide minerals. FEMS Microbiology Ecology 34, 197-206.

Ferris, F.G., Fyfe, W.S. \& Beveridge, T.J. (1988). Metallic ion binding by Bacillus subtilis: Implications for the fossilization of microorganisms. Geology 16, 149-152.

Folk, R.L. (1992). Bacteria and nannobacteria revealed in hardgrounds, calcite cements, native sulfur, sulfide minerals, and travertines. Geological Society of America, Abstracts with Programs 24, 104.

Folk, R.L. (1993). SEM imaging of bacteria and nannobacteria in carbonate sediments and rocks. J. Sediment. Petrol. 63, 990-999.

Folk, R.L. \& Lynch, F.L. (1997). The possible role of nannobacteria (dwarf bacteria) in clay-mineral diagenesis and the importance of careful sample preparation in high-magnification SEM study. J. Sediment. Petrol. 67, 583-589.

Fox, S.W., Syren, R.M., Ingram, M., Price, B.J. \& Costello, J. (1983). Ancient microspheres: abiogenic, protobiogenic, or biogenic? Precambrian Research 23, 1-8.

Fratesi, S.E., Lynch, F.L., Kirkland, B.L. \& Brown, L.R. (2004). Effects of SEM preparation techniques on the appearance of bacteria and biofilms in the Carter Sandstone. J. Sediment. Res. 74, 858-867.

Gensel, P.G. (1980). Devonian in situ spores: a survey and discussion. Review of Palaeobotany and Palynology 30 101-132.

Gerdes, G. \& Krumbein, W.E. (1987). Biolaminated deposits, eds Bhattacharji, S., Friedman, G.M., Neugebauer, H.J. \& Seilacher, A. Lecture Notes In Earth Sciences 9, 183. Springer, Berlin.

Glasspool, I.J., Edwards, D. \& Axe, L. (in press). Charcoal in the Early Devonian: a wildfire derived Konservat-Lagerstätte. Review of Palaeobotany and Palynology.

Grimes, S.T., Brock, F., Rickard, D., Davies, K.L., Edwards, D., Briggs, D.E.G. \& Parkes, R.J. (2001). Understanding fossilization: experimental pyritization of plants. Geology 29, 123-126.

Grimes, S.T., Davies, K.L., Butler, I.B., Brock, F., Edwards, D., Rickard, D., Briggs, D.E.G. \& Parkes, R.J. (2002). Fossil plants from the Eocene London Clay: the use of pyrite textures to determine the mechanism of pyritization. J. Geological Soc. 159 493-501.

Kirkland, B.L., Lynch, F.L., Rahnis, M.A., Folk, R.L., Molineux, I.J. \& McLean, R.J.C. (1999). Alternative origins for nannobacteria-like objects in calcite. Geology 27, 347-350. 
Liebig, K., Westall, F. \& Schmitz, M. (1996). A study of fossil microstructures from the Eocene Messel Formation using transmission electron microscopy. Neues Jahrbuch für Geologie und Paläontologie Monatshefte 4, 218-231.

Martill, D.M. (1987). Prokaryote mats replacing soft tissues in Mesozoic marine reptiles. Modern Geology 11, 265-269.

Martill, D.M. \& Wilby, P.R. (1994). Lithified prokaryotes associated with fossil soft tissues from the Santana Formation (Cretaceous) of Brazil. Kaupia 4, 71-77.

Martin, D., Briggs, D.E.G. \& Parkes, R.J. (2003). Experimental mineralization of invertebrate eggs and the preservation of Neoproterozoic embryos. Geology 31, 39-42.

McKay, D.S., Gibson Jr., E.K. Thomas-Keprta, K.L., Vali, H., Romanek, C.S., Clemett, S.J., Chillier, X.D.F., Maechling, C.R. \& Zare, R.N (1996). Search for past life on Mars: possible relic biogenic activity in Martian meteorite ALH 84001. Science 273, 924-930.

Nealson, K.H. (1997). Sediment bacteria: who's there, what are they doing, and what's new? Ann. Rev. of Earth and Planetary Sci. Lett. 25, 403-434

Oehler, J.H. \& Schopf, J.W. (1971). Artificial microfossils: experimental studies of permineralization of blue-green algae in silica. Science 174, $1229-1231$.

Pike, J. (2004). Personal communication.

Reynolds, E.S. (1963). The use of lead citrate at high $\mathrm{pH}$ as an electronopaque stain in electron microscopy. J. Cell Biology 17, 208-212.

Richter, G. (1994). Bacteria and bacteria-like structures from the oil-shale of Messel. Kaupia 4, 21-28.

Schopf, J.W. \& Walter, M.R. (1983). Archean microfossils: new evidence of ancient microbes. In Earth's Earliest Biosphere, Its Origin and Evolution, ed. Schopf, J.W., pp. 214-239. Princeton University Press, Princeton

Schopf, J.W., Kudryavtsev, A.B., Agresti, D.G., Wdowiak, T.J. \& Czaja, A.D. (2002). Laser-Raman imagery of Earth's earliest fossils. Nature 416, 73-76.

Sillitoe, R.H., Folk, R.L. \& Saric, N. (1996). Bacteria as mediators of copper sulfide enrichment during weathering. Science 272, 1153-1155.

Spurr, A.R. (1969). Low viscosity epoxy resin embedding medium for electron microscopy. J. Ultra. Res. 26, 31-43.

Thomas-Keprta, K.L., McKay, D.S., Wentworth, S.J., Stevens, T.O., Taunton, A.E., Allen, C.C., Coleman, A., Gibson, Jr., E.K. \& Romanek, C.S. (1998). Bacterial mineralization patterns in basaltic aquifers: implications for possible life in martian meteorite ALH84001. Geology 26, 1031-1034.
Tschech, A. \& Pfennig, N. (1984). Growth yield increase linked to caffeate reduction in Acetobacterium woodii. Arch. Microbiol. 137, 163-167.

Toporski, J.K.W., Steele, A., Westall, F., Thomas-Keprta, K.L. \& McKay, D.S. (2002). The simulated silicification of bacteria - new clues to the modes and timing of bacterial preservation and implications for the search of extraterrestrial microfossils. Astrobiol. 2, 1-26.

Toporski, J., Steele, A., McKay, D.S. \& Westall, F. (2003). Bacterial films in Astrobiology: the importance of life detection. In Fossil and Recent Biofilms. A Natural History of Life on Earth, eds Krumbein, W.E., Paterston, D.M. \& Zavarzin, G.A., ch. 31, pp. 429-445. Kluwer Academic Publishers, Dordrecht/Boston/London.

Walters, C.C., Margulis, L. \& Barghoorn, E.S. (1977) On the experimental silicification of microorganisms. I. Microbial growth on organosilicon compounds. Precambrian Research 5, 241-248.

Wellman, C.H., Edwards, D. \& Axe, L. (1998a). Ultrastructure of laevigate hilate cryptospores in sporangia and spore masses from the Upper Silurian and Lower Devonian of the Welsh Borderland. Philos. Trans. Roy. Soc. London B353, 1983-2004.

Wellman, C.H., Edwards, D. \& Axe, L. (1998b). Permanent dyads in sporangia and spore masses from the Lower Devonian of the Welsh Borderland. Bot. J. Linn. Soc. 127, 117-147.

Westall, F. (1994). Silicified bacteria and associated biofilm from the deep-sea sedimentary environment. Kaupia 4, 29-43.

Westall, F. (1999). The nature of fossil bacteria: a guide to the search for extraterrestrial life. J. Geophys. Res. 104, 16 437-16451.

Westall, F. \& Folk, R.L. (2003). Exogenous carbonaceous microstructures in Early Archaean cherts and BIFs from the Isua Greenstone Belt: implications for the search for life in ancient rocks. Precambrian Research 126, 313-330.

Westall, F. \& Rincé, Y. (1994). Biofilms, microbial mats and microbeparticle interactions: electron microscope observations from diatomaceous sediments. Sedimentology 41, 147-162.

Westall, F., Boni, L. \& Guerzoni, E. (1995). The experimental silicification of microorganisms. Palaeontology 38, 495-528.

Westall, F., de Wit, M.J., Dann, J., van der Gaast, S., de Ronde, C.E.J. \& Gerneke, D. (2001). Early Archean fossil bacteria and biofilms in hydrothermally-influenced sediments from the Barberton greenstone belt, South Africa. Precambrian Research 106, 93-116.

Whitman, W.B., Coleman, D.C. \& Wiebe, W.J. (1998). Prokaryotes: the unseen majority. Proc. Nat. Acad. Sci. USA 95, 6578-6583.

Wilkinson, H.P. (2003). Fossil actinomycete filaments and fungal hyphae in dicotyledonous wood from the Eocene London Clay, Isleof-Sheppey, Kent, England. Bot. J. Linn. Soc. 142, 383-394. 


\section{Appendix A. Mesofossil preparation details}

\begin{tabular}{|c|c|c|c|c|c|}
\hline $\begin{array}{l}\text { Batch with } \\
\text { stub numbers }\end{array}$ & Locality & $\begin{array}{l}\text { Collection } \\
\text { date }\end{array}$ & $\begin{array}{l}\text { Preparation } \\
\text { date }\end{array}$ & $\begin{array}{l}\text { SEM } \\
\text { date }\end{array}$ & Preparation details \\
\hline $\mathrm{T} 76 / 1, \mathrm{~T} 76 / 8$ & Targrove & ? & ? & LA 1992 & Macerate prepared in Cardiff by Lindsey Axe using standard HF acid maceration techniques. \\
\hline $\mathrm{HD}(\mathrm{UF}) 103 / 5$ & $\begin{array}{l}\text { North Brown } \\
\text { Clee Hill }\end{array}$ & ? & ? & UF 1988 & Macerate prepared in Cardiff, details unknown, by Una Fanning. \\
\hline $\begin{array}{l}\mathrm{HD}(\mathrm{UF}) 216 \mathrm{~A} / 3,6,10 \\
\mathrm{HD}(\mathrm{UF}) 216 \mathrm{~B} / 1-4\end{array}$ & $\begin{array}{l}\text { North Brown } \\
\text { Clee Hill }\end{array}$ & ? & ? & UF 1989 & Macerate prepared in Cardiff, details unknown, by Una Fanning. \\
\hline $\begin{array}{l}\mathrm{HD} 1 / 4,1 / 5,2 / 2,2 / 3 \\
2 / 4,3 / 1,5 / 2,6 / 1,7 / 1\end{array}$ & $\begin{array}{l}\text { North Brown } \\
\text { Clee Hill }\end{array}$ & December 1990 & ? & LA 1991 & Macerate prepared in Cardiff by Lindsey Axe using standard HF acid maceration techniques. \\
\hline HD65/1 & $\begin{array}{l}\text { North Brown } \\
\text { Clee Hill }\end{array}$ & December 1990 & February 1994 & LA 1994 & $\begin{array}{l}\text { Macerate prepared in Cardiff by Lindsey Axe using standard HF acid maceration techniques } \\
\text { then washed through a tea-strainer to concentrate larger pieces and air-dried. }\end{array}$ \\
\hline HD447/1,447/2 & $\begin{array}{l}\text { North Brown } \\
\text { Clee Hill }\end{array}$ & December 1990 & October 2002 & LA 2005 & $\begin{array}{l}\text { Specimens from a macerate prepared in Cardiff in } 2002 \text { by Lindsey Axe and stored dry (sample } \\
\text { concentrated by washing rock with water before HF maceration, no heavy mineral used, } \\
>250 \mu \mathrm{m} \text { fraction, air-dried) were put in a clean petri dish on } 10.1 .2005 \text { and tap water was } \\
\text { added. This was then left in the laboratory near a window. The lid was lifted from time to time } \\
\text { and the water swirled. On } 28.2 .2005 \text { the contents had almost evaporated so the dish was air- } \\
\text { dried by removing the lid and placing it in a fume cupboard. Specimens were then chosen at } \\
\text { random and mounted on SEM stubs using sticky C discs and coated with a thin coat of gold/ } \\
\text { palladium and examined in the FE-SEM. The remaining specimens were removed from the } \\
\text { petri dish and the lower surface of the petri dish was also coated with a thin coat of gold/ } \\
\text { palladium and examined in the FE-SEM. }\end{array}$ \\
\hline HD450/1,450/2 & $\begin{array}{l}\text { North Brown } \\
\text { Clee Hill }\end{array}$ & December 1990 & October 2002 & LA 2005 & $\begin{array}{l}\text { Specimens from a macerate prepared in Cardiff in } 2002 \text { by Lindsey Axe and stored dry } \\
\text { (sample concentrated by washing rock with water before HF maceration, no heavy mineral } \\
\text { used, }>250 \mu \mathrm{m} \text { fraction air-dried) were chosen at random and mounted on SEM stubs using } \\
\text { sticky C discs and coated with a thin coat of gold/palladium and examined in the FE-SEM. }\end{array}$ \\
\hline $\mathrm{HD}(\mathrm{KH}) 914,914 \mathrm{~A}$ & $\begin{array}{l}\text { North Brown } \\
\text { Clee Hill }\end{array}$ & ? & ? & KH 1998 & Macerate prepared in Cardiff, details unknown, by Kate Habgood. \\
\hline $\mathrm{L}(\mathrm{A}) 2 / 3$ & Ludford Lane & $\begin{array}{r}\text { DE original } \\
\text { collection }\end{array}$ & November 1991 & LA 1992 & Macerate prepared in Cardiff by Lindsey Axe using standard HF acid maceration techniques. \\
\hline LL6/6,11D,12C,12E & Ludford Lane & $\begin{array}{l}\text { Manchester collection } \\
1992\end{array}$ & February 1994 & LA 1994 & $\begin{array}{l}\text { Material macerated and sorted by Andy Jeram in Manchester from } 1.6 \mathrm{~m} \text { horizon, stored in } \\
\text { diluted } \mathrm{HCl} \text {. }\end{array}$ \\
\hline LL26/3,29/6,30/1 & Ludford Lane & $\begin{array}{l}\text { Manchester collection } \\
1992\end{array}$ & ? & LA 1995 & $\begin{array}{l}\text { Macerate prepared in Manchester by Phil Manning using standard HF acid maceration } \\
\text { techniques and stored in diluted } \mathrm{HCl} \text {. From preparation labelled 1.6/good. }\end{array}$ \\
\hline $\begin{array}{l}\text { LL38/1,38/2,38/3 } \\
49 / 2,50 / 5,51 / 4\end{array}$ & Ludford Lane & $\begin{array}{l}\text { Manchester collection } \\
1992\end{array}$ & ? & LA 1995 & $\begin{array}{l}\text { Macerate prepared in Manchester by Phil Manning using standard HF acid maceration } \\
\text { techniques and stored in diluted HCl. From preparation labelled 1.6/7. }\end{array}$ \\
\hline $\begin{array}{l}\mathrm{LL}(\mathrm{BP}) 2,2 / 1,2 / 4, \\
5 / 4,6 / 2,26 \mathrm{~A}, \\
\text { 29/2,GT1 }\end{array}$ & Ludford Lane & $\begin{array}{l}\text { Manchester collection } \\
1992\end{array}$ & $?$ & LA 2003 & $\begin{array}{l}\text { Macerates prepared in Manchester by Phil Manning using standard HF acid maceration } \\
\text { techniques and stored in diluted } \mathrm{HCl} \text {. Organic residues from various horizons at LL were } \\
\text { pooled and washed through a } 500 \mu \mathrm{m} \text { sieve in } 2003 \text {. Fraction larger than } 500 \mu \mathrm{m} \text { was put into a } \\
\text { petri dish, all cuticle was removed using a pipette and the remaining coalified residues were air- } \\
\text { dried. }\end{array}$ \\
\hline
\end{tabular}

dried. 
Appendix B. Dimensions (in $\mu \mathrm{m}$ )

Categories $1(a)-(g)$, bacteria $(i)$

\begin{tabular}{|c|c|c|c|c|c|}
\hline Category & Specimen number & $n$ & $\begin{array}{l}\text { Average } \\
\text { diameter }\end{array}$ & $\begin{array}{l}\text { Range in diameter } \\
\min -\max \end{array}$ & $\begin{array}{l}\text { Max/Min } \\
\text { diameter }\end{array}$ \\
\hline $1 \mathrm{a}-\mathrm{Si}$ & $\begin{array}{l}\text { LL26/3 } \\
\text { LL29/6 } \\
\text { LL30/1 } \\
\text { Overall dimensions }\end{array}$ & $\begin{array}{l}20 \\
10 \\
10 \\
10 \\
\mathbf{5 0}\end{array}$ & $\begin{array}{l}0.07 \\
0.06 \\
0.08 \\
0.05 \\
\mathbf{0 . 0 7}\end{array}$ & $\begin{array}{l}0.04-0.1 \\
0.04-0.1 \\
0.05-0.1 \\
0.03-0.08 \\
\mathbf{0 . 0 3}-\mathbf{0 . 1}\end{array}$ & $\begin{array}{l}2.3 \\
2.7 \\
2.2 \\
2.7\end{array}$ \\
\hline $1 \mathrm{~b}-\mathrm{Si}$ & $\begin{array}{l}\text { LL38/1 } \\
\text { LL38/2 } \\
\text { LL38/3 } \\
\text { LL49/2 } \\
\text { LL50/5 } \\
\text { LL51/4 } \\
\text { Overall dimensions }\end{array}$ & $\begin{array}{r}30 \\
30 \\
30 \\
50 \\
50 \\
35 \\
40 \\
265\end{array}$ & $\begin{array}{l}0.3 \\
0.4 \\
0.5 \\
0.4 \\
0.4 \\
0.4 \\
0.4 \\
\mathbf{0 . 4}\end{array}$ & $\begin{array}{l}0.1-0.5 \\
0.2-0.5 \\
0.5-0.5 \\
0.3-0.5 \\
0.2-0.5 \\
0.3-0.5 \\
0.3-0.5 \\
\mathbf{0 . 1}-\mathbf{0 . 5}\end{array}$ & $\begin{array}{l}3.6 \\
2.1 \\
1.0 \\
1.8 \\
2.2 \\
2.0 \\
1.7\end{array}$ \\
\hline $1 \mathrm{c}-\mathrm{CaF}_{2}$ & $\begin{array}{l}\mathrm{HD} 2 / 3 \\
\mathrm{HD} 2 / 4 \\
\mathrm{HD} 3 / 1 \\
\mathrm{HD} 5 / 2 \\
\mathrm{HD} 7 / 1 \\
\text { Overall dimensions }\end{array}$ & $\begin{array}{r}50 \\
50 \\
50 \\
50 \\
20 \\
50 \\
50 \\
40 \\
20 \\
50 \\
50 \\
50 \\
50 \\
7 \\
12 \\
50 \\
\mathbf{6 4 9}\end{array}$ & $\begin{array}{l}0.7 \\
0.6 \\
0.7 \\
0.7 \\
0.6 \\
0.9 \\
1.0 \\
0.6 \\
0.9 \\
0.6 \\
0.7 \\
0.6 \\
0.6 \\
0.6 \\
0.5 \\
0.5 \\
\mathbf{0 . 7}\end{array}$ & $\begin{array}{l}0.4-1.0 \\
0.3-0.9 \\
0.5-1.1 \\
0.3-1.4 \\
0.5-0.7 \\
0.3-1.8 \\
0.3-2.0 \\
0.3-1.4 \\
0.4-1.4 \\
0.3-1.1 \\
0.2-0.9 \\
0.3-0.9 \\
0.2-1.2 \\
0.5-0.9 \\
0.2-0.8 \\
0.3-0.8 \\
\mathbf{0 . 2}-\mathbf{2 . 0}\end{array}$ & $\begin{array}{l}2.5 \\
3 \\
2.2 \\
4.7 \\
1.4 \\
6 \\
6.7 \\
4.7 \\
3.5 \\
3.7 \\
4.5 \\
3 \\
6 \\
1.8 \\
4 \\
2.7\end{array}$ \\
\hline $1 \mathrm{~d}-\mathrm{CaF}_{2}$ & $\begin{array}{l}\text { T76/1 } \\
\text { T76/8 } \\
\text { Overall dimensions }\end{array}$ & $\begin{array}{l}20 \\
30 \\
20 \\
70\end{array}$ & $\begin{array}{l}0.7 \\
0.7 \\
0.6 \\
\mathbf{0 . 7}\end{array}$ & $\begin{array}{l}0.3-0.9 \\
0.3-1.2 \\
0.3-1.2 \\
\mathbf{0 . 3}-\mathbf{1 . 2}\end{array}$ & $\begin{array}{l}3 \\
4 \\
4\end{array}$ \\
\hline $1 \mathrm{e}-\mathrm{CaF}_{2}$ & $\begin{array}{l}\text { HD(UF) } 103 / 5 \\
\text { HD6/1 } \\
\text { Overall dimensions }\end{array}$ & $\begin{array}{l}10 \\
12 \\
41 \\
63\end{array}$ & $\begin{array}{l}0.8 \\
0.7 \\
0.7 \\
\mathbf{0 . 7}\end{array}$ & $\begin{array}{l}0.6-0.9 \\
0.5-0.9 \\
0.4-1.0 \\
\mathbf{0 . 4 - 1 . 0}\end{array}$ & $\begin{array}{l}1.5 \\
1.8 \\
2.5\end{array}$ \\
\hline 1f & $\begin{array}{l}\mathrm{HD} 2 / 2 \\
\mathrm{HD} 5 / 2 \\
\mathrm{HD} 65 / 1 \\
\mathrm{LL}(\mathrm{BP}) 5 / 4 \\
\text { Overall dimensions }\end{array}$ & $\begin{array}{r}20 \\
30 \\
20 \\
52 \\
40 \\
20 \\
30 \\
25 \\
10 \\
247\end{array}$ & $\begin{array}{l}0.9 \\
0.8 \\
0.8 \\
0.7 \\
0.9 \\
0.9 \\
1.0 \\
1.0 \\
0.4 \\
\mathbf{0 . 8}\end{array}$ & $\begin{array}{l}0.6-1.1 \\
0.5-1.1 \\
0.6-1.1 \\
0.3-1.0 \\
0.4-1.4 \\
0.6-1.1 \\
0.5-1.2 \\
0.7-1.3 \\
0.3-0.5 \\
\mathbf{0 . 3}-1.4\end{array}$ & $\begin{array}{l}1.8 \\
2.2 \\
1.8 \\
3.3 \\
3.5 \\
1.8 \\
2.4 \\
1.9 \\
1.7 \\
\mathbf{4 . 7}\end{array}$ \\
\hline $1 \mathrm{~g}$ & $\begin{array}{l}\text { LL12E } \\
\text { Overall dimensions }\end{array}$ & $\begin{array}{r}10 \\
20 \\
20 \\
20 \\
25 \\
20 \\
115\end{array}$ & $\begin{array}{l}0.6 \\
0.9 \\
0.9 \\
0.9 \\
0.5 \\
0.4 \\
\mathbf{0 . 7}\end{array}$ & $\begin{array}{l}0.4-0.8 \\
0.6-1.5 \\
0.6-1.3 \\
0.5-1.4 \\
0.3-0.7 \\
0.2-0.9 \\
\mathbf{0 . 2}-\mathbf{1 . 5}\end{array}$ & $\begin{array}{l}2 \\
2.5 \\
2.2 \\
2.8 \\
2.3 \\
4.5 \\
7.5\end{array}$ \\
\hline Bacteria (i) & $\begin{array}{l}\text { Coccoid bacteria cultured } \\
\text { from soil from a molehill }\end{array}$ & $\begin{array}{l}30 \\
12 \\
14 \\
17 \\
10 \\
83\end{array}$ & $\begin{array}{l}1.3 \\
1.2 \\
1.3 \\
1.2 \\
1.2 \\
1.2\end{array}$ & $\begin{array}{l}1.0-1.6 \\
1.0-1.3 \\
1.0-1.5 \\
1.1-1.4 \\
1.1-1.3 \\
\mathbf{1 . 0}-\mathbf{1 . 6}\end{array}$ & $\begin{array}{l}1.6 \\
1.3 \\
1.5 \\
1.3 \\
1.2\end{array}$ \\
\hline
\end{tabular}


Appendix B (cont.)

Categories 2(a)-(c)

\begin{tabular}{|c|c|c|c|c|}
\hline Category & Specimen number & $\begin{array}{l}\text { Length } \\
\text { of rod }\end{array}$ & $\begin{array}{l}\text { Width } \\
\text { of rod }\end{array}$ & $\mathrm{L} / \mathrm{W}$ ratio \\
\hline \multirow[t]{31}{*}{$2 \mathrm{a}$} & $\mathrm{HD}(\mathrm{UF}) 216 \mathrm{~B} / 3$ & 1.4 & 0.5 & 2.7 \\
\hline & \multirow[t]{2}{*}{$\mathrm{HD} 2 / 2$} & 4.5 & 0.8 & 5.6 \\
\hline & & 3.3 & 0.5 & 6.0 \\
\hline & \multirow[t]{2}{*}{$\mathrm{HD} 3 / 1$} & 5.0 & 0.4 & 12.8 \\
\hline & & 2.8 & 0.6 & 5.1 \\
\hline & HD5/2 & $>5.5$ & 1.2 & 4.5 \\
\hline & \multirow[t]{2}{*}{ HD6/1 } & 4.2 & 1.1 & 4 \\
\hline & & 8.6 & 0.8 & 10.4 \\
\hline & HD7/1 & $>2.4$ & 0.4 & 5.7 \\
\hline & HD450/1 & 0.7 & 0.1 & 5.9 \\
\hline & \multirow[t]{3}{*}{$\mathrm{HD} 450 / 2$} & $>2.0$ & 0.3 & 6.2 \\
\hline & & 1.6 & 0.3 & 5 \\
\hline & & 0.8 & 0.1 & 6.3 \\
\hline & \multirow[t]{2}{*}{$\operatorname{LL}(\mathrm{A}) 2 / 3$} & 3.3 & 0.5 & 7.1 \\
\hline & & 2.5 & 0.5 & 5.4 \\
\hline & \multirow[t]{3}{*}{ LL6/6 } & 2.7 & 0.2 & 9 \\
\hline & & $>7.2$ & 0.5 & 13.3 \\
\hline & & 2.5 & 0.3 & 7.4 \\
\hline & \multirow[t]{4}{*}{ LL11D } & 2.7 & 0.2 & 12.4 \\
\hline & & 2.9 & 0.3 & 8.9 \\
\hline & & 1.9 & 0.4 & 5.5 \\
\hline & & $>1.3$ & 0.4 & 3.7 \\
\hline & LL12C & 2.0 & 0.3 & 7.4 \\
\hline & LL12E & 0.6 & 0.06 & 10.5 \\
\hline & LL29/6 & 5.8 & 1.0 & 6.0 \\
\hline & LL38/1 & 0.7 & 0.1 & 6.7 \\
\hline & LL38/2 & 0.8 & 0.1 & 8.1 \\
\hline & LL38/3 & $>1.0$ & 0.4 & 2.6 \\
\hline & $\mathrm{LL}(\mathrm{BP}) 2$ & 1.0 & 0.2 & 5.7 \\
\hline & \multirow[t]{2}{*}{$\mathrm{LL}(\mathrm{BP}) 5 / 4$} & $>2.4$ & 0.3 & 9.2 \\
\hline & & $>3.2$ & 0.5 & 6.2 \\
\hline \multirow[t]{28}{*}{$2 b$} & \multirow[t]{10}{*}{$\mathrm{HD}(\mathrm{UF}) 216 \mathrm{~A} / 3$} & 3.1 & 1.1 & 2.7 \\
\hline & & 2.8 & 1.1 & 2.5 \\
\hline & & 2.3 & 1.3 & 1.7 \\
\hline & & 2.7 & 1.1 & 2.5 \\
\hline & & 2.5 & 1.1 & 2.3 \\
\hline & & 2.2 & 1.4 & 1.6 \\
\hline & & 2.4 & 1.2 & 2.0 \\
\hline & & 2.7 & 1.2 & 2.3 \\
\hline & & 2.7 & 1.2 & 2.3 \\
\hline & & 2.5 & 1.3 & 2.0 \\
\hline & \multirow[t]{8}{*}{$\mathrm{HD}(\mathrm{UF}) 216 \mathrm{~A} / 10$} & 1.4 & 0.4 & 3.5 \\
\hline & & 1.6 & 0.3 & 5.3 \\
\hline & & 1.5 & 0.3 & 5 \\
\hline & & 1.3 & 0.4 & 3.3 \\
\hline & & 1.4 & 0.3 & 4.7 \\
\hline & & 2.0 & 0.3 & 6.7 \\
\hline & & 1.0 & 0.4 & 2.5 \\
\hline & & 1.5 & 0.3 & 5 \\
\hline & \multirow[t]{10}{*}{$\mathrm{LL}(\mathrm{BP}) 6 / 2$} & 1.4 & 0.5 & 2.6 \\
\hline & & 1.0 & 0.4 & 2.4 \\
\hline & & 1.3 & 0.5 & 2.6 \\
\hline & & 1.1 & 0.4 & 2.5 \\
\hline & & 1.1 & 0.4 & 2.7 \\
\hline & & 1.3 & 0.7 & 1.9 \\
\hline & & 1.2 & 0.5 & 2.4 \\
\hline & & 1.1 & 0.5 & 2.1 \\
\hline & & 1.5 & 0.5 & 3 \\
\hline & & 1.4 & 0.6 & 2.4 \\
\hline
\end{tabular}


Categories 2(a)-(c) (cont.)

\begin{tabular}{|c|c|c|c|c|}
\hline Category & Specimen number & $\begin{array}{l}\text { Length } \\
\text { of rod }\end{array}$ & $\begin{array}{l}\text { Width } \\
\text { of rod }\end{array}$ & $\mathrm{L} / \mathrm{W}$ ratio \\
\hline \multirow[t]{11}{*}{$2 \mathrm{c}$} & $\operatorname{LL}(\mathrm{BP}) 2 / 1$ & 2.0 & $0.4 \mathrm{w}$ & 5 \\
\hline & & 2.2 & $0.5 \mathrm{w}$ & 4.2 \\
\hline & & 1.9 & $0.5 \mathrm{w}$ & 3.8 \\
\hline & & 1.8 & $0.5 \mathrm{w}$ & 3.6 \\
\hline & & 2.1 & $0.6 \mathrm{w}$ & 3.8 \\
\hline & & 1.7 & $0.5 \mathrm{w}$ & 3.4 \\
\hline & & 2.0 & $0.6 \mathrm{~d}$ & 3.3 \\
\hline & & 2.0 & $0.5 \mathrm{~d}$ & 4.0 \\
\hline & & 2.1 & $0.4 \mathrm{~d}$ & 4.9 \\
\hline & LL(BP)29/2 & 2.1 & $0.5 \mathrm{w}$ & 4.1 \\
\hline & LL(BP)GT1 & 2.1 & $0.5 \mathrm{w}$ & 4.1 \\
\hline
\end{tabular}

Categories 2(d), 3(a), 4(i)-(iii), bacteria(ii) and (iii)

\begin{tabular}{|c|c|c|c|c|c|c|c|c|}
\hline Category & Specimen number & $n$ & $\begin{array}{l}\text { Average } \\
\text { length }\end{array}$ & $\begin{array}{l}\text { Range in } \\
\text { length } \\
\text { min-max }\end{array}$ & $\begin{array}{l}\text { Max/Min } \\
\text { length }\end{array}$ & $\begin{array}{l}\text { Average } \\
\text { width }\end{array}$ & $\begin{array}{l}\text { Range in } \\
\text { width } \\
\text { min-max }\end{array}$ & $\begin{array}{l}\text { Max/Min } \\
\text { width }\end{array}$ \\
\hline \multirow[t]{2}{*}{$2 d$} & $\mathrm{HD}(\mathrm{KH}) 9 / 14$ & 107 & 2.1 & $1.0-4.1$ & 4.1 & 0.6 & $0.4-1.0$ & 2.5 \\
\hline & $\mathrm{HD}(\mathrm{KH}) 9 / 14 \mathrm{~A}$ & 107 & 1.6 & $1.0-2.1$ & 2.1 & 0.5 & $0.5-0.6$ & 1.2 \\
\hline \multirow[t]{2}{*}{$3 a$} & LL(BP)2 & 5 & 3.8 & $3.5-4.3$ & 1.2 & 2.6 & $2.5-2.7$ & 1.1 \\
\hline & $\mathrm{LL}(\mathrm{BP}) 2 / 4$ & 4 & 3.9 & $3.3-4.4$ & 1.3 & 2.0 & $1.9-2.1$ & 1.1 \\
\hline 4(i) & $\mathrm{HD}(\mathrm{UF}) 216 \mathrm{~B} / 3$ & 7 & 2.3 & $1.2-3.0$ & 2.5 & 0.5 & $0.4-0.7$ & 1.8 \\
\hline 4(ii) & $\mathrm{HD}(\mathrm{UF}) 216 \mathrm{~A} / 6$ & 2 & 2.5 & $2.2-2.8$ & 1.3 & 0.9 & $0.6-1.1$ & 1.8 \\
\hline 4(iii) & $\mathrm{HD}(\mathrm{UF}) 216 \mathrm{~B} / 4$ & 5 & 1.2 & $0.9-1.5$ & 1.7 & 0.3 & $0.3-0.4$ & 1.3 \\
\hline \multirow[t]{9}{*}{ Bacteria (ii) } & $\mathrm{HD} 447 / 1$ & 7 & 2.0 & $1.5-2.4$ & 1.6 & 0.8 & $0.7-0.9$ & 1.3 \\
\hline & HD447/2 & 8 & 0.4 & $0.3-0.6$ & 2 & 0.2 & $0.2-0.3$ & 1.5 \\
\hline & Petri dish & 3 & 0.8 & $0.6-1.0$ & 1.7 & 0.4 & $0.4-0.4$ & 1 \\
\hline & & 2 & 0.9 & $0.8-0.9$ & 1.1 & 0.4 & $0.4-0.5$ & 1.3 \\
\hline & & 3 & 1.0 & $0.8-1.2$ & 1.5 & 0.4 & $0.3-0.4$ & 1.3 \\
\hline & & 12 & 1.1 & $0.7-1.3$ & 1.9 & 0.4 & $0.3-0.5$ & 1.7 \\
\hline & Petri dish +2 weeks & 6 & 0.9 & $0.6-1.2$ & 2 & 0.4 & $0.3-0.6$ & 2 \\
\hline & & 2 & 0.9 & $0.9-0.9$ & 1 & 0.5 & $0.5-0.5$ & 1 \\
\hline & & 3 & 0.7 & $0.6-0.8$ & 1.3 & 0.4 & $0.3-0.4$ & 1.3 \\
\hline Bacteria (iii) & Pseudoanabaena catenata & 46 & 2.3 & $1.7-3.0$ & 1.8 & 1.5 & $1.2-1.6$ & 1.4 \\
\hline
\end{tabular}

\section{Appendix C. Chemical compositions in wt.\% (figure numbers included if same as area analysed)}

\begin{tabular}{|c|c|c|c|c|c|c|c|c|c|c|c|c|c|c|c|c|c|c|c|c|c|}
\hline Category & $\begin{array}{l}\text { Specimen } \\
\text { number }\end{array}$ & Area analysed & $\mathrm{C}$ & $\mathrm{O}$ & $\mathrm{F}$ & $\mathrm{Na}$ & $\mathrm{Mg}$ & $\mathrm{Al}$ & $\mathrm{Si}$ & $\mathrm{P}$ & $\mathrm{S}$ & $\mathrm{Cl}$ & $\mathrm{K}$ & $\mathrm{Ca}$ & $\mathrm{Ti}$ & $\mathrm{Fe}$ & Co & $\mathrm{Cu} \mathrm{Br}$ & $\mathrm{Ba}$ & W & Th \\
\hline \multirow[t]{6}{*}{ 1a } & LL26/3 & Microbioids & 65 & 33 & & & & $<1$ & $<1$ & & & 1 & & & & & & & & & \\
\hline & Fig. 1(c) & Sporangium & 66 & 31 & & & & $<1$ & & & & 3 & & & & & & & & & \\
\hline & LL29/6 & Microbioids & 72 & 20 & & & & & 3 & & & 2 & & & & & & 3 & & & \\
\hline & & Spore & 79 & 20 & & & & & $<1$ & & & 2 & & & & & & & & & \\
\hline & LL30/1 & Microbioids & 68 & 18 & & 4 & & 1 & 3 & & & 4 & & & & & & 3 & & & \\
\hline & & Sporangium & 70 & 17 & & 5 & & 1 & $<1$ & & & 5 & & & & & & 2 & & & \\
\hline \multirow[t]{14}{*}{$1 \mathrm{~b}$} & LL38/1 & Microbioid & 57 & 34 & & & & & 7 & & & & & & & & & 2 & & & \\
\hline & & Sporangium & 69 & 31 & & & & & & & & & & & & & & & & & \\
\hline & LL38/1 & Microbioid & 66 & 27 & & & & & 5 & & & & & & & & & 2 & & & \\
\hline & & Spore & 70 & 28 & & & & & & & & & & & & & & 2 & & & \\
\hline & LL38/1 & Microbioid & 60 & 29 & & $<1$ & & & 8 & & & & & & & & & 3 & & & \\
\hline & & Spore & 74 & 21 & & 1 & & & & & & & & & & & & 4 & & & \\
\hline & LL38/2 & Microbioid & 62 & 31 & & & & & 5 & & & 2 & & & & & & & & & \\
\hline & & Spore & 64 & 33 & & & & & & & & 3 & & & & & & & & & \\
\hline & LL38/2 & Microbioid & 60 & 28 & & & & & 7 & & & 2 & & & & & & 3 & & & \\
\hline & & Spore & 72 & 21 & & & & & & & & 4 & & & & & & 3 & & & \\
\hline & LL38/2 & Microbioid & 61 & 28 & & & & & 6 & & & 2 & & & & & & 2 & & & \\
\hline & & Spore & 76 & 20 & & & & & & & & 3 & & & & & & 2 & & & \\
\hline & LL38/3 & Microbioid & 58 & 31 & & & & & 8 & & & 2 & & & & & & 1 & & & \\
\hline & Fig. 1(i) & Nematophyte & 73 & 21 & & & & & 2 & & & 2 & & & & & & 2 & & & \\
\hline
\end{tabular}


Appendix C (cont.)

\begin{tabular}{|c|c|c|c|c|c|c|c|c|c|c|c|c|c|c|c|c|c|c|c|c|c|}
\hline Category & $\begin{array}{l}\text { Specimen } \\
\text { number }\end{array}$ & Area analysed & $\mathrm{C}$ & $\mathrm{O}$ & $\mathrm{F}$ & $\mathrm{Na}$ & $\mathrm{Mg}$ & $\mathrm{Al}$ & $\mathrm{Si}$ & $P$ & $\mathrm{~S}$ & $\mathrm{Cl}$ & $\mathrm{K}$ & $\mathrm{Ca}$ & $\mathrm{Ti}$ & $\mathrm{Fe}$ & Co & $\mathrm{Cu}$ & $\mathrm{Br}$ & $\mathrm{Ba}$ & $\mathrm{W} \quad \mathrm{Th}$ \\
\hline \multirow[t]{12}{*}{ 1b (cont.) } & LL38/3 & Microbioid & 65 & 29 & & & & & 4 & & & 1 & & & & & & 1 & & & \\
\hline & Fig. $4(\mathrm{k})$ & Nematophyte & 78 & 20 & & & & & & & & 2 & & & & & & 1 & & & \\
\hline & LL49/2 & Microbioid & 71 & 27 & & & & $<1$ & 1 & & & $<1$ & & $<1$ & & & & $<1$ & & & \\
\hline & Fig. 1(j) & Axis & 76 & 22 & & & & $<1$ & & & & $<1$ & & $<1$ & & & & $<1$ & & & \\
\hline & LL49/2 & Microbioid & 62 & 34 & & $<1$ & & & 3 & & & & & & & & & $<1$ & & & \\
\hline & & Axis & 76 & 23 & & $<1$ & & & & & & $<1$ & & $<1$ & & & & $<1$ & & & \\
\hline & LL50/5 & Microbioid & 58 & 36 & & & & & 5 & & & & & & & & & $<1$ & & & \\
\hline & & Axis & 76 & 23 & & & & $<1$ & & & & & & & & & & $<1$ & & & \\
\hline & LL50/5 & Microbioid & 67 & 27 & & & & & 4 & & & & & & & & & 1 & & & \\
\hline & & Axis & 79 & 19 & & $<1$ & & $<1$ & & & & $<1$ & & & & & & & & & \\
\hline & LL51/4 & Microbioid & 59 & 34 & & & & & 6 & & & $<1$ & & $<1$ & & & & $<1$ & & & \\
\hline & & Axis & 79 & 19 & & & & $<1$ & & & & $<1$ & & $<1$ & & & & 1 & & & \\
\hline \multirow[t]{14}{*}{ 1c } & $\mathrm{HD} 1 / 4$ & Microbioid & 27 & 26 & 33 & & & & & & & & & 15 & & & & & & & \\
\hline & & Sporangium & 92 & & & & & & & & & & & 8 & & & & & & & \\
\hline & $\mathrm{HD} 2 / 2$ & Microbioid & 37 & 14 & 24 & & & & & & & & & 18 & & 2 & & 5 & & & \\
\hline & & Sporangium & 58 & 19 & & & & & & & & & & 4 & & 6 & & 13 & & & \\
\hline & $\mathrm{HD} 2 / 4$ & Microbioid & 25 & 17 & 25 & & & & & & & & & 18 & & 15 & & & & & \\
\hline & & Sporangium? & 68 & & & & & & & & & & & 8 & & 24 & & & & & \\
\hline & $\mathrm{HD} 3 / 1$ & Microbioid & 29 & 13 & 42 & & & & & & & & & 16 & & & & & & & \\
\hline & Fig. 4(b) & Sporangium & 100 & & & & & & & & & & & & & & & & & & \\
\hline & $\mathrm{HD} 5 / 2$ & Microbioid & 51 & 12 & 24 & $<1$ & $<1$ & $<1$ & & & & $<1$ & & 11 & $<1$ & & & $<1$ & & & \\
\hline & & Sporangium & 71 & 22 & 3 & & & & & & $<1$ & $<1$ & & 1 & $<1$ & & & $<1$ & $<1$ & & \\
\hline & $\mathrm{HD} 5 / 2$ & Microbioid & 56 & 17 & 20 & $<1$ & $<1$ & $<1$ & & & & $<1$ & & 6 & $<1$ & & & $<1$ & & & \\
\hline & Fig. 2(e) & Sporangium & 68 & 30 & & $<1$ & & $<1$ & & & & $<1$ & & $<1$ & $<1$ & $<1$ & & $<1$ & & & \\
\hline & HD7/1 & Microbioid & 45 & 12 & 33 & & & & & & & & & 9 & & & & & & & \\
\hline & & Pachytheca & 75 & 23 & & & & & & & & & & 2 & & & & & & & \\
\hline \multirow[t]{4}{*}{$1 d$} & $\mathrm{~T} 76 / 1$ & Microbioids & 52 & 27 & 8 & 2 & & 3 & 1 & & & & & 6 & & & & & & & \\
\hline & Fig. 3D & Spore & 59 & 38 & & 3 & & & & & & & & $<1$ & & & & & & & \\
\hline & $\mathrm{T} 76 / 8$ & Microbioids & 33 & 35 & 13 & 8 & & 4 & 1 & & & 1 & $<1$ & 4 & & & & & & & \\
\hline & & Spore & 50 & 42 & & 6 & & $<1$ & & & & 2 & & & & & & & & & \\
\hline \multirow[t]{4}{*}{ 1e } & $\mathrm{HD}$ (UF) $103 / 5$ & Microbioids & 40 & & 30 & & & & & & & & & 30 & & & & & & & \\
\hline & Fig. 3(e) & Spore & 83 & & & & & & & & & & & 17 & & & & & & & \\
\hline & $\mathrm{HD}(\mathrm{UF}) 6 / 1$ & Microbioid & 51 & & 36 & & & & & & & & & 13 & & & & & & & \\
\hline & & Sporangium wall & 90 & & & & & & & & & & & 10 & & & & & & & \\
\hline \multirow[t]{15}{*}{ if } & $\mathrm{HD} 2 / 2$ & Framboid & 77 & 19 & & & & & & & & & & & & 1 & & 2 & & & \\
\hline & & Microbioid & 42 & 18 & 21 & & $<1$ & & & & & & & 6 & 12 & & & & & & \\
\hline & & Sporangium & 76 & 17 & & & & & & & & & & & & 5 & & 2 & & & \\
\hline & & Rod & 53 & 14 & 19 & & $<1$ & $<1$ & & & & & & 6 & 6 & & & 1 & & & \\
\hline & HD5/2 & Framboid & 75 & 24 & & & & & & & $<1$ & $<1$ & & $<1$ & $<1$ & & & $<1$ & & & \\
\hline & & Spore ornament & 80 & 18 & & & & $<1$ & & & $<1$ & $<1$ & & $<1$ & $<1$ & & & $<1$ & & & \\
\hline & HD5/2 & Framboid & 74 & 25 & & & & $<1$ & & & $<1$ & $<1$ & & $<1$ & $<1$ & & & $<1$ & & & \\
\hline & Fig. 2(e) & Microbioid & 56 & 17 & 20 & $<1$ & $<1$ & $<1$ & & & & $<1$ & & 6 & $<1$ & & & $<1$ & & & \\
\hline & & Sporangium & 68 & 30 & & $<1$ & & $<1$ & & & & $<1$ & & $<1$ & $<1$ & $<1$ & & $<1$ & & & \\
\hline & & Spore ornament & 70 & 27 & 1 & $<1$ & & $<1$ & & & & $<1$ & & $<1$ & $<1$ & & & $<1$ & & & \\
\hline & HD65/1 & Framboid & 77 & 20 & & 1 & & & $<1$ & & $<1$ & $<1$ & & & $<1$ & & & & & & \\
\hline & Fig. 3(1) & Spore ornament & 79 & 18 & & 1 & & $<1$ & $<1$ & & $<1$ & $<1$ & & & $<1$ & & & & & & \\
\hline & $\operatorname{LL}(\mathrm{BP}) 5 / 4$ & Framboid & 75 & 24 & & & & & & & & $<1$ & & & & & & & & & \\
\hline & & Spore & 75 & 25 & & & & & & & & $<1$ & & & & & & & & & \\
\hline & & Rod & 59 & 35 & & & & & & & & & & & 6 & & & & & & \\
\hline \multirow[t]{7}{*}{$1 \mathrm{~g}$} & LL6/6 & Sphere 1 & 61 & 31 & & 7 & & & & & & & $<1$ & $<1$ & $<1$ & & & $<1$ & & & \\
\hline & & Sphere 2 & 61 & 29 & & 9 & & & & & & $<1$ & $<1$ & & & & & $<1$ & & & \\
\hline & & Spore & 61 & 27 & & 8 & & & & & & $<1$ & $<1$ & $<1$ & & & & $<1$ & & & \\
\hline & & Rod & 49 & 32 & & 6 & & & & & & & $<1$ & $<1$ & 11 & & & $<1$ & & & \\
\hline & LL12E & Sphere & 59 & 38 & & 3 & & & & & & & $<1$ & & & & & & & & \\
\hline & Fig. 6L & Spore & 61 & 35 & & 3 & & & & & & & & & & & & $<1$ & & & \\
\hline & & Rod & 61 & 35 & & 2 & & & & & & & & & 1 & & & & & & \\
\hline \multirow[t]{6}{*}{$2 \mathrm{a}$} & $\mathrm{HD}(\mathrm{UF}) 216 \mathrm{~B} / 3$ & Rod & 68 & 19 & & & & & & & & 1 & & 1 & 11 & & & & & & \\
\hline & Fig. 7(b) & Spore & 73 & 26 & & & & & & & & & & 2 & & & & & & & \\
\hline & $\mathrm{HD} 2 / 2$ & Rod & 53 & 14 & 19 & & $<1$ & $<1$ & & & & & & 6 & 6 & & & 1 & & & \\
\hline & Fig. 4(a) & Sporangium? & 76 & 17 & & & & & & & & & & & & 5 & & 2 & & & \\
\hline & $\mathrm{HD} 2 / 4$ & Rod & 37 & & 16 & & & & & & & & & 16 & 23 & 8 & & & & & \\
\hline & & Fossil & 68 & & & & & & & & & & & 8 & & 24 & & & & & \\
\hline
\end{tabular}


Appendix C (cont.)

\begin{tabular}{|c|c|c|c|c|c|c|c|c|c|c|c|c|c|c|c|c|c|c|c|c|}
\hline Category & $\begin{array}{l}\text { Specimen } \\
\text { number }\end{array}$ & Area analysed & $\mathrm{C}$ & $\mathrm{O}$ & $\mathrm{F}$ & $\mathrm{Na}$ & $\mathrm{Mg}$ & $\mathrm{Al}$ & $\mathrm{Si}$ & $P$ & $\mathrm{~S}$ & $\mathrm{Cl}$ & $\mathrm{K}$ & $\mathrm{Ca}$ & $\mathrm{Ti}$ & $\mathrm{Fe} \mathrm{C}$ & Co $\mathrm{C}$ & $\mathrm{Cu} \mathrm{Br}$ & $\mathrm{Ba} \mathrm{W}$ & Th \\
\hline \multirow[t]{41}{*}{ 2a (cont. $)$} & $\mathrm{HD} 3 / 1$ & Rod & 45 & 41 & & & & & & & & & & 3 & 11 & & & & & \\
\hline & Fig. 4(b) & Sporangium & 100 & & & & & & & & & & & & & & & & & \\
\hline & HD3/1 & Rod & 66 & 17 & 12 & & & & & & & & & 3 & 2 & & & & & \\
\hline & Fig. 4(c) & Spore & 79 & 21 & & & & & & & & & & & & & & & & \\
\hline & HD5/2 & Rod & 39 & 11 & & & & & & & & & & $<1$ & 47 & & & 2 & & \\
\hline & Fig. 4(d) & & & & & & & & & & & & & & & & & & & \\
\hline & HD6/1 & Rod & 24 & 32 & & & & & & & & & & 3 & 41 & & & & & \\
\hline & Fig. 4(f) & Sporangium & 90 & & & & & & & & & & & 10 & & & & & & \\
\hline & HD6/1 & Rod & 34 & 32 & 8 & & & & & & & & & $<1$ & 23 & 2 & & & & \\
\hline & & Sporangium & 81 & 19 & & & & & & & & & & & & & & & & \\
\hline & HD7/1 & Rod & 62 & 12 & 19 & & & & & & & & & 7 & $<1$ & & & & & \\
\hline & & Pachytheca & 75 & 23 & & & & & & & & & & 2 & & & & & & \\
\hline & HD450/1 & Rod & 76 & 15 & & & & & & & 2 & 2 & & & 4 & $<1$ & & & & \\
\hline & & Cuticle? & 82 & 14 & & & & & & & 2 & 2 & & & & $<1$ & & $<1$ & & \\
\hline & HD450/2 & Rod & 75 & 19 & & & & & & & 3 & $<1$ & & & $<1$ & $2<$ & $<1$ & & & \\
\hline & & Cuticle? & 78 & 18 & & & & & & & 2 & $<1$ & & & & $1<$ & $<1$ & & & \\
\hline & LL(A) $2 / 3$ & Rod & 42 & 29 & & 7 & & & & & & & & 2 & 14 & & & 6 & & \\
\hline & & Spore & 59 & 21 & & 7 & & & & & & & & & & & & 13 & & \\
\hline & LL6/6 & Rod & 48 & 37 & & 8 & & & & & & & $<1$ & & 7 & & & & & \\
\hline & & Spore & 61 & 29 & & 8 & & & & & & & $<1$ & & & & & $<1$ & & \\
\hline & LL6/6 & Rod & 49 & 32 & & 6 & & & & & & & $<1$ & $<1$ & 11 & & & $<1$ & & \\
\hline & & Spore & 64 & 27 & & 8 & & & & & & $<1$ & $<1$ & $<1$ & & & & $<1$ & & \\
\hline & LL11D & Rod & 53 & 35 & & 3 & & & & & & $<1$ & & $<1$ & 7 & & & & & \\
\hline & Fig. 4(g) & Spore & 63 & 33 & & 4 & & & & & & & & $<1$ & & & & & & \\
\hline & LL11D & Rod & 35 & 43 & & 3 & & & & & & $<1$ & & $<1$ & 18 & & & & & \\
\hline & Fig. 4(h) & Spore & 59 & 36 & & 3 & & & & & & & & & & & & & & \\
\hline & LL12E & Rod & 61 & 35 & & 2 & & & & & & & & & 1 & & & & & \\
\hline & Fig. 6(1) & Spore & 61 & 35 & & 3 & & & & & & & & & & & & $<1$ & & \\
\hline & $\begin{array}{l}\text { LL29/6 } \\
\text { Fig. 1(a) }\end{array}$ & Rod & 24 & 40 & & & & & 3 & & & 1 & & & 32 & & & & & \\
\hline & LL38/1 & Rod & 61 & 36 & & & & & & & & & & & 3 & & & & & \\
\hline & & Sporangium & 69 & 31 & & & & & & & & & & & & & & & & \\
\hline & LL38/2 & Rod & 61 & 34 & & & & & & & & 3 & & & 3 & & & & & \\
\hline & & Spore & 64 & 33 & & & & & & & & 3 & & & & & & & & \\
\hline & LL38/3 & Rod & 70 & 22 & & & & & & & & 2 & & & 4 & & & 1 & & \\
\hline & Fig. 4(k) & Nematophyte & 78 & 20 & & & & & & & & 2 & & & & & & 1 & & \\
\hline & LL(BP)2 & Rod & 40 & 34 & & & & & & & & 4 & & 3 & 19 & & & & & \\
\hline & Fig. 4(1) & Sporangium & 56 & 30 & & & & & & & & 8 & & 7 & & & & & & \\
\hline & $\mathrm{LL}(\mathrm{BP}) 5 / 4$ & Rod & 59 & 35 & & & & & & & & & & & 6 & & & & & \\
\hline & Fig. 4(j) & Spore & 75 & 25 & & & & & & & & $<1$ & & & & & & & & \\
\hline & $\operatorname{LL}(\mathrm{BP}) 5 / 4$ & Rod & 58 & 35 & & $<1$ & & & & & & $<1$ & & $<1$ & 5 & & & & & \\
\hline & & Spore & 72 & 27 & & $<1$ & & & & & $<1$ & $<1$ & & $<1$ & & & & & & \\
\hline \multirow[t]{4}{*}{$2 \mathrm{~b}$} & LL(BP) $6 / 2$ & Rod & 34 & 55 & & & & & & & & 3 & & 8 & & & & & & \\
\hline & & $\begin{array}{l}\text { Arthropod } \\
\text { cuticle }\end{array}$ & 39 & 49 & & & & & & & & 4 & & 8 & & & & & & \\
\hline & $\mathrm{LL}(\mathrm{BP}) 6 / 2$ & Rod & 30 & 53 & & & & & & & & 5 & & 13 & & & & & & \\
\hline & & $\begin{array}{l}\text { Arthropod } \\
\text { cuticle }\end{array}$ & 33 & 46 & & & & & & & & 6 & & 15 & & & & & & \\
\hline \multirow[t]{14}{*}{$2 \mathrm{c}$} & $\mathrm{LL}(\mathrm{BP}) 2 / 1$ & Mineral & 41 & 16 & 16 & & & & & & & $<1$ & 1 & 3 & & & & & & 22 \\
\hline & Fig. 4(q) & Mineral & 59 & 19 & & & $<1$ & & $<1$ & & $<1$ & 1 & $<1$ & 9 & & & & & & 9 \\
\hline & & Spore & 65 & 32 & & & $<1$ & & & & $<1$ & $<1$ & & 2 & & & & & & \\
\hline & $\mathrm{LL}(\mathrm{BP}) 2 / 1$ & Mineral & 46 & 18 & 17 & $<1$ & $<1$ & & & & & $<1$ & 1 & 2 & & & & $<1$ & 1 & 13 \\
\hline & Fig. 4(u) & Mineral & 49 & 22 & 15 & $<1$ & $<1$ & & & & & $<1$ & $<1$ & 2 & & & & $<1$ & $<1$ & 8 \\
\hline & & Spore & 63 & 31 & & $<1$ & $<1$ & & & & & $<1$ & & 4 & & & & & & \\
\hline & LL(BP)2/1 & Mineral & 29 & 11 & & & & & & & & 1 & 4 & 14 & & & & & 4 & 38 \\
\hline & Fig. 4(s) & Sporangium & 39 & 22 & & & & & & & & 3 & 2 & 34 & & & & & & \\
\hline & LL(BP)2/1 & Mineral & 35 & 18 & 23 & $<1$ & & & & & & & 2 & 3 & & & & & & 19 \\
\hline & & Sporangium & 54 & 21 & & & & & & & 2 & 1 & & 17 & & & & 4 & & \\
\hline & LL(BP)GT1 & Mineral & 72 & 22 & & & & & & & & & & 3 & & & & & & 4 \\
\hline & Fig. 4(t) & Fossil & 76 & 21 & & & & & & & & & & 3 & & & & & & \\
\hline & LL(BP)GT1 & Mineral & 65 & 23 & & & & & & & & & & 5 & & & & & & 7 \\
\hline & no gold & Fossil & 71 & 24 & & & & & & & & & & 6 & & & & & & \\
\hline
\end{tabular}


Appendix C (cont.)

\begin{tabular}{|c|c|c|c|c|c|c|c|c|c|c|c|c|c|c|c|c|c|c|c|c|c|c|}
\hline Category & $\begin{array}{l}\text { Specimen } \\
\text { number }\end{array}$ & Area analysed & $\mathrm{C}$ & $\mathrm{O}$ & $\mathrm{F}$ & $\mathrm{Na}$ & $\mathrm{Mg}$ & $\mathrm{Al}$ & $\mathrm{Si}$ & $\mathrm{P}$ & $\mathrm{S}$ & $\mathrm{Cl}$ & $\mathrm{K}$ & $\mathrm{Ca}$ & $\mathrm{Ti}$ & $\mathrm{Fe}$ & Co & $\mathrm{Cu}$ & $\mathrm{Br}$ & $\mathrm{Ba}$ & W & Th \\
\hline \multirow[t]{15}{*}{$2 \mathrm{~d}$} & \multirow[t]{4}{*}{$\mathrm{HD}(\mathrm{KH}) 914$} & Microbioid 1 & 58 & 27 & & 2 & & $<1$ & & & & 2 & $<1$ & 3 & & $<1$ & & 1 & & & 5 & \\
\hline & & Microbioid 2 & 58 & 27 & & 2 & $<1$ & & & & & 3 & $<1$ & 3 & & $<1$ & & 1 & & & 4 & \\
\hline & & Microbioid 3 & 57 & 29 & & 2 & $<1$ & & & & & 2 & $<1$ & 3 & & $<1$ & & 1 & & & 4 & \\
\hline & & Sporangium & 61 & 22 & & 2 & $<1$ & & & & & 3 & 1 & 4 & & $<1$ & & 2 & & & 2 & \\
\hline & \multirow{8}{*}{$\begin{array}{l}\mathrm{HD}(\mathrm{KH}) 914 \\
\text { washed - } \\
\text { different area } \\
\mathrm{HD}(\mathrm{KH}) 914 \mathrm{a} \\
\text { Fig. } 5(\mathrm{i})\end{array}$} & Microbioid 1 & 70 & 21 & & & $<1$ & & & & & & & 6 & & $<1$ & & 2 & & & & \\
\hline & & Microbioid 2 & 69 & 24 & & & $<1$ & $<1$ & & & & & & 4 & & $<1$ & & 1 & & & & \\
\hline & & Sporangium & 70 & 23 & & & $<1$ & $<1$ & & & & & & 4 & & $<1$ & & 1 & & & $<1$ & \\
\hline & & Microbioid 1 & 64 & 29 & & 2 & & & & & 2 & $<1$ & $<1$ & $<1$ & & $<1$ & & $<1$ & & & $<1$ & \\
\hline & & Microbioid 2 & 67 & 23 & & 1 & & & & & 5 & & $<1$ & $<1$ & & 3 & & $<1$ & & & $<1$ & \\
\hline & & Microbioid 3 & 66 & 26 & & 2 & & & & & 4 & $<1$ & $<1$ & $<1$ & & 2 & & $<1$ & & & $<1$ & \\
\hline & & Microbioid 4 & 64 & 29 & & 2 & & & & & 2 & $<1$ & $<1$ & $<1$ & & $<1$ & & $<1$ & $<1$ & & $<1$ & \\
\hline & & Sporangium & 66 & 24 & & 1 & & & & & 5 & $<1$ & $<1$ & $<1$ & & 3 & & $<1$ & & & & \\
\hline & \multirow{3}{*}{$\begin{array}{c}\mathrm{HD}(\mathrm{KH}) 914 \mathrm{a} \\
\text { washed }- \text { same } \\
\text { area Fig. } 5(\mathrm{i})\end{array}$} & Microbioid 1 & 64 & 29 & & 1 & & $<1$ & & & 3 & $<1$ & $<1$ & $<1$ & & 1 & & $<1$ & & & $<1$ & \\
\hline & & Microbioid 4 & 64 & 29 & & 1 & & $<1$ & & & 2 & & $<1$ & $<1$ & & $<1$ & & $<1$ & & & $<1$ & \\
\hline & & Sporangium & 66 & 24 & & $<1$ & & $<1$ & & & 5 & & $<1$ & $<1$ & & 3 & & $<1$ & & & & \\
\hline \multirow[t]{6}{*}{$3 a$} & \multirow[t]{3}{*}{ LL(BP) 2} & Cyanobacterium & 63 & 29 & & & & & & & & 4 & & 3 & & & & 2 & & & & \\
\hline & & Sporangium & 57 & 37 & & & & & & & & 2 & & 4 & & & & & & & & \\
\hline & & Spheres & 50 & 38 & & & & & & & & 3 & & 6 & & 2 & & 1 & & & & \\
\hline & $\mathrm{LL}(\mathrm{BP}) 2 / 4$ & Cyanobacterium & 66 & 24 & & & $<1$ & & $<1$ & & $<1$ & 3 & & 3 & & & & 1 & & & & \\
\hline & \multirow[t]{2}{*}{ Fig. $6 \mathrm{~F}$} & Sporangium & 71 & 26 & & & & & & & $<1$ & $<1$ & & 1 & & & & & & & & \\
\hline & & Spheres & 64 & 33 & & & & & 2 & & $<1$ & $<1$ & & $<1$ & & & & & & & & \\
\hline $3 b$ & $\operatorname{LL}(\mathrm{A}) 2 / 3$ & Filament 1 & 59 & 29 & & 6 & & & & & & & & & & & & 6 & & & & \\
\hline & & Filament 2 & 59 & 29 & & 5 & & & & & & & & & & & & 7 & & & & \\
\hline & & Filament 3 & 60 & 40 & & & & & & & & & & & & & & & & & & \\
\hline & & Spore & 58 & 25 & & 8 & & & & & & & & & & & & 10 & & & & \\
\hline & LL12C & Microbioid 1 & 82 & 18 & & & & & & & & $<1$ & & $<1$ & & & & $<1$ & & & & \\
\hline & Fig. 6(i) & Microbioid 2 & 81 & 19 & & & & & & & & $<1$ & & $<1$ & & & & $<1$ & & & & \\
\hline & & Fossil tube 1 & 83 & 16 & & & & & & & & $<1$ & & $<1$ & & & & $<1$ & & & & \\
\hline & & Fossil tube 2 & 86 & 13 & & & & & & & & $<1$ & & $<1$ & & & & $<1$ & & & & \\
\hline & LL(BP)2 & Fungus? & 61 & 34 & & & & & & & & 2 & & 3 & & & & & & & & \\
\hline & & Sporangium & 57 & 37 & & & & & & & & 2 & & 4 & & & & & & & & \\
\hline 4(i) & $\mathrm{HD}(\mathrm{UF}) 216 \mathrm{~B} / 3$ & Filament & 72 & 27 & & & & & & & & & & 1 & & & & & & & & \\
\hline & Fig. 7(b) & Spore & 73 & 26 & & & & & & & & & & 2 & & & & & & & & \\
\hline & & Sphere & 74 & 25 & & & & & & & & & & 1 & & & & & & & & \\
\hline & & Rod & 68 & 19 & & & & & & & & 1 & & 1 & 11 & & & & & & & \\
\hline 4(iii) & $\mathrm{HD}(\mathrm{UF}) 216 \mathrm{~B} / 4$ & Rod 1 & 81 & 19 & & & & & & & & & & & & & & & & & & \\
\hline & Fig. 8(d) & $\operatorname{Rod} 2$ & 82 & 18 & & & & & & & & & & & & & & & & & & \\
\hline & & Sphere & 73 & 20 & & & & & & & & & & 1 & & & & 5 & & & & \\
\hline & & Sheet & 77 & 19 & & & & & & & & & & 1 & & & & 3 & & & & \\
\hline & & Spore & 76 & 16 & & & & & & & & & & & & & & 7 & & & & \\
\hline 4(iv) & $\mathrm{HD}(\mathrm{UF}) 216 \mathrm{~B} / 1$ & Filament & 72 & 24 & & & & & & & & & & 1 & & & & 3 & & & & \\
\hline & & Sphere & 68 & 29 & & & & & & & & & & & & & & 4 & & & & \\
\hline & & Sheet & 68 & 27 & & & & & & & & & & 2 & & & & 3 & & & & \\
\hline & & Spore & 71 & 28 & & & & & & & & & & 1 & & & & & & & & \\
\hline $4(\mathrm{v})$ & $\mathrm{HD}(\mathrm{UF}) 216 \mathrm{~B} / 2$ & Spheres & 66 & 24 & & & & & & & & & & 2 & & & & 8 & & & & \\
\hline & & Sheet & 70 & 20 & & & & & & & & 3 & & 2 & & & & 5 & & & & \\
\hline & & Spore & 76 & 15 & & & & & & & & 5 & & 3 & & & & & & & & \\
\hline Extant bacteria (i) & Soil bacteria & Coccoid cell & 44 & 7 & & & & 46 & $<1$ & & & & $<1$ & & & & & 2 & & & & \\
\hline & washed & Stub & 18 & 3 & & & & 75 & & & & & & & & & & 4 & & & & \\
\hline Extant bacteria (ii) & HD447/1 & Rod & 60 & 27 & & 2 & $<1$ & & $<1$ & & 2 & 1 & $<1$ & $<1$ & & 1 & & & & & 5 & \\
\hline & & Disc & 65 & 23 & & 1 & $<1$ & & & & 5 & $<1$ & $<1$ & $<1$ & & 3 & & & & & 1 & \\
\hline & & Cuticle? & 69 & 25 & & 1 & $<1$ & & & & 1 & 1 & $<1$ & $<1$ & & $<1$ & & & & & 1 & \\
\hline & HD447/2 & Rod & 69 & 27 & & $<1$ & $<1$ & & & & $<1$ & $<1$ & & $<1$ & & $<1$ & & & & & $<1$ & \\
\hline & Fig. 9(b) & Cuticle? & 73 & 25 & & $<1$ & $<1$ & & & & $<1$ & $<1$ & & $<1$ & & $<1$ & & $<1$ & & & & \\
\hline & HD447/2 & Rod 1 & 75 & 24 & & & & & & & & $<1$ & & $<1$ & & $<1$ & & & & & & \\
\hline & & $\operatorname{Rod} 2$ & 77 & 22 & & & & & & & & $<1$ & & $<1$ & & & & & & & $<1$ & \\
\hline & & Cuticle? & 79 & 21 & & & & & & & & $<1$ & & $<1$ & & & & & & & & \\
\hline & HD447/2 & Rod 1 & 76 & 23 & & & & & & & & $<1$ & & $<1$ & $<1$ & & & $<1$ & & & $<1$ & \\
\hline & & $\operatorname{Rod} 2$ & 76 & 23 & & & & & & & & $<1$ & & $<1$ & & $<1$ & & & & & $<1$ & \\
\hline & & Cuticle? & 79 & 21 & & & & & & & & $<1$ & & $<1$ & & & & & & & & \\
\hline
\end{tabular}


Appendix C (cont.)

\begin{tabular}{|c|c|c|c|c|c|c|c|c|c|c|c|c|c|c|c|c|c|c|c|c|c|c|}
\hline Category & $\begin{array}{l}\text { Specimen } \\
\text { number }\end{array}$ & Area analysed & $\mathrm{C}$ & $\mathrm{O}$ & $\mathrm{F}$ & $\mathrm{Na}$ & $\mathrm{Mg}$ & $\mathrm{Al}$ & $\mathrm{Si}$ & $\mathrm{P}$ & $\mathrm{S}$ & $\mathrm{Cl}$ & $\mathrm{K}$ & $\mathrm{Ca}$ & $\mathrm{Ti}$ & $\mathrm{Fe}$ & $\mathrm{Co}$ & $\mathrm{Cu}$ & $\mathrm{Br}$ & $\mathrm{Ba}$ & W & $\mathrm{Th}$ \\
\hline \multirow{9}{*}{$\begin{array}{l}\text { Extant bacteria } \\
\text { (ii) (cont.) }\end{array}$} & \multirow{6}{*}{$\begin{array}{l}\text { Bacteria on } \\
\text { petri dish } \\
\text { Bacteria on } \\
\text { petri dish }\end{array}$} & $\operatorname{Rod} 2$ & 29 & $\$ 9$ & & 4 & 1 & $<1$ & 22 & & & & $<1$ & 3 & & & & & $<1$ & & 2 & \\
\hline & & Petri dish & 16 & 50 & & 4 & 2 & $<1$ & 25 & & & & $<1$ & 3 & & & & & & & & \\
\hline & & Rod 1 & 13 & 52 & & 6 & 2 & $<1$ & 22 & & & $<1$ & $<1$ & 3 & & & & & & & 1 & \\
\hline & & $\operatorname{Rod} 2$ & 9 & 53 & & 6 & 2 & $<1$ & 25 & & & $<1$ & $<1$ & 3 & & & & & & & 1 & \\
\hline & & Rod 3 & 19 & 50 & & 4 & 1 & & 20 & & & $<1$ & $<1$ & 2 & & & & & $<1$ & & 2 & \\
\hline & & Petri dish & 8 & 51 & & 5 & 2 & & 29 & & & & $<1$ & 3 & & & & & 1 & & & \\
\hline & \multirow{3}{*}{$\begin{array}{l}\text { Bacteria on } \\
\text { petri dish }\end{array}$} & Rod 1 & 7 & 54 & & 6 & 2 & $<1$ & 26 & & & $<1$ & $<1$ & 3 & & & & & & & 1 & \\
\hline & & Rod 2 & 13 & 52 & & 5 & 2 & $<1$ & 25 & & & $<1$ & $<1$ & 3 & & & & & & & & \\
\hline & & Petri dish & 18 & 49 & & 4 & 1 & $<1$ & 24 & & & & $<1$ & 3 & & & & & & & & \\
\hline \multirow{12}{*}{$\begin{array}{l}\text { Extant bacteria } \\
\text { (iii) }\end{array}$} & \multirow{4}{*}{$\begin{array}{l}\text { Pseudoanabaena } \\
\text { catenata } \\
\text { Pseudoanabaena } \\
\text { catenata } \\
\text { Fig. } 9(1)\end{array}$} & Filament 1 & 75 & 23 & & & $<1$ & & & $<1$ & $<1$ & & & $<1$ & & & & & & & & \\
\hline & & Filament 2 & 74 & 23 & & & $<1$ & & & & $<1$ & $<1$ & & $<1$ & & & & $<1$ & & & & \\
\hline & & Filament 1 & 74 & 23 & & $<1$ & $<1$ & & & 1 & $<1$ & & & $<1$ & & $<1$ & & & & & & \\
\hline & & Filament 2 & 69 & 27 & & $<1$ & $<1$ & & & 1 & $<1$ & & & $<1$ & & & & & & & & \\
\hline & \multirow{2}{*}{$\begin{array}{l}\text { Pseudoanabaena } \\
\text { catenata }\end{array}$} & Filament & 68 & 29 & & $<1$ & $<1$ & & & & & $<1$ & & $<1$ & & & & & & & & \\
\hline & & Cover slip & 76 & 24 & & & & & & & & & & & & & & & & & & \\
\hline & \multirow{3}{*}{$\begin{array}{l}\text { Plectonema } \\
\text { boryanum }\end{array}$} & Filament 1 & 69 & 29 & & $<1$ & $<1$ & & & & & $<1$ & $<1$ & $<1$ & & & & & & & & \\
\hline & & Filament 2 & 79 & 21 & & & $<1$ & & & & & $<1$ & & & & & & & & & & \\
\hline & & Cover slip & 74 & 26 & & & $<1$ & & & & & $<1$ & $<1$ & $<1$ & & & & & & & & \\
\hline & \multirow{3}{*}{$\begin{array}{l}\text { Plectonema } \\
\text { boryanum }\end{array}$} & Filament 1 & 67 & 30 & & $<1$ & $<1$ & & & & & 1 & $<1$ & $<1$ & & & & & & & & \\
\hline & & Filament 2 & 75 & 22 & & $<1$ & $<1$ & & & & & $<1$ & $<1$ & $<1$ & & & & & & & & \\
\hline & & Cover slip & 75 & 23 & & & $<1$ & & & & & $<1$ & $<1$ & $<1$ & & & & & & & & \\
\hline
\end{tabular}

